Stratigraphic and Geomorphic Framework of Uppermost Cenozoic Deposits in the Southern Delmarva Peninsula, Virginia and Maryland

I.S. G1:OHOGGCA, SURVEY PROEESSIONAL PAPER 1067G

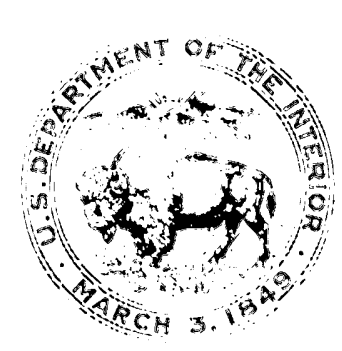




\title{
Stratigraphic and Geomorphic Framework of Uppermost Cenozoic Deposits in the Southern Delmarva Peninsula, Virginia and Maryland
}

\author{
By R. B. MIXON
}

SURFACE AND SHALLOW SUBSURFACE GEOLOGIC STUDIES IN THE EMERGED COASTAL PLAIN OF THE MIDDLE ATLANTIC STATES

U.S. GEOLOGICAL SURVEY PROFESSIONAL PAPER 1067-G

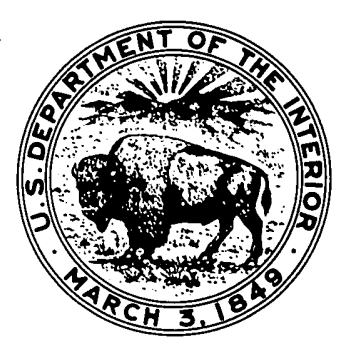


DEPARTMENT OF THE INTERIOR

DONALD PAUL HODEL, Secretary

\section{U.S. GEOLOGICAL SURVEY}

Dallas L. Peck, Director

Library of Congress Cataloging in Publication Data

Mixon, Robert B.

Stratigraphic and geomorphic framework of uppermost Cenozoic deposits in the southern Delmarva Peninsula, Virginia and Maryland.

(Surface and shallow subsurface geologic studies in the emerged Coastal Plain of the Middle Atlantic States) (U.S. Geological Survey professional paper ; $1067-G$ )

Bibliography: p.G51

Supt. of Docs. no.: I 19.16:1067-G

1. Geology, Stratigraphic-Cenozoic. 2. Geology-Delmarva Peninsula. I. Title. II. Series. III. Series: Geological Survey professional paper; $1067-\mathrm{G}$.

QE690.M59 $1984 \quad 551.7 ' 8 \quad 84-600095$

For sale by the Distribution Branch, U.S. Geological Survey 604 South Pickett Street, Alexandria, VA 22304 


\section{CONTENTS}

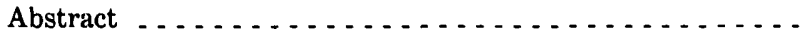

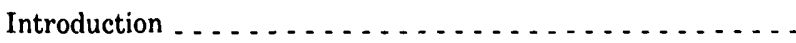

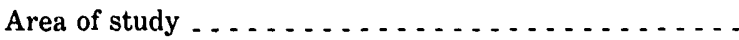

Previous investigations $\ldots \ldots \ldots \ldots \ldots \ldots$

Acknowledgments . . . . . . . . . . . . . . . . .

Geomorphology ... . . . . . . . . . . . . . . . . . . Delmarva Peninsula and Chesapeake-Delaware lowland . Southern Delmarva Peninsula . . . . . . . . . . . . . .

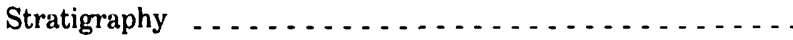
Upper Tertiary deposits $\ldots \ldots \ldots \ldots \ldots \ldots . . .6$

Eastover Formation $\ldots \ldots \ldots \ldots \ldots \ldots$

Lithology .....................

Stratigraphic relationships $\ldots . . .6 . . .6$

Fauna $\ldots \ldots \ldots \ldots$

Paleoenvironment . . . . . . . . . . . . .

Age and correlation . . . . . . . . . . . . .

Relationship to hydrologic units .........

Yorktown Formation .... . . . . . . . . . .

Previous investigations ..............

Lithostratigraphy . . . . . . . . . . . . .

Lower shelly sand member . . . . . . . . . .

Tunnels Mill Member ...............

Upper shelly sand member . . . . . . . . . . .

Depositional environments and paleogeography of the Yorktown Formation . . . . . . . . . . . .

Relationship to hydrologic units, age, and correlation . . . . . . . . . . . . . . . .

Quaternary deposits .................

Deposits of upland area . . . . . . . . . . . . .

Omar Formation . . . . . . . . . . . . . .

Definition ......................

Accomack Member ................

Description of sedimentary facies ....

Interpretation of sedimentary environments ..................

Vertical and lateral facies succession . -

Age and correlation . . . . . . . . . . .

Nassawadox Formation . . . . . . . . . . .

Definition ..................

General description . . . . . . . . . . .

Type section ................

Stumptown Member ............... Definition ...................

Lithology and type section . . . . . . . . Stratigraphic relationships ......... .

Butlers Bluff Member . . . . . . . . . . . .

Definition ......................

Lithology and type section . . . . . . .

Fauna ...................

\begin{tabular}{|c|c|c|}
\hline Page & & Page \\
\hline G1 & Stratigraphy-Continued & \\
\hline 2 & Quaternary deposits - Continued & \\
\hline 4 & Deposits of upland area - Continued & \\
\hline 4 & Nassawadox Formation - Continued & \\
\hline 4 & Butlers Bluff Member - Continued & \\
\hline 4 & Paleoenvironment $\ldots \ldots \ldots \ldots \ldots$ & G33 \\
\hline 4 & Paleogeography $\ldots \ldots \ldots \ldots$ & 35 \\
\hline 5 & Occohannock Member . - & 5 \\
\hline 5 & Definition & 5 \\
\hline 5 & nd reference sections $\ldots \ldots \ldots$ & 5 \\
\hline 5 & c relationships _. & 5 \\
\hline 8 & onment and paleogeography - & 6 \\
\hline 8 & lation $\ldots \ldots-1-\ldots$ & 36 \\
\hline 8 & ancock lowland $\ldots \ldots \ldots$. . . . & 37 \\
\hline 8 & tion $\ldots \ldots \ldots$ & 57 \\
\hline 8 & ing and definition . . . . . . & 37 \\
\hline 10 & $\ldots \ldots \ldots \ldots$ & \\
\hline 10 & thickness, and stratigraphic & \\
\hline 10 & relationships $\ldots \ldots \ldots \ldots \ldots$ & \\
\hline 10 & Paleoclimate & \\
\hline 10 & rrelation . . . . . . & \\
\hline 11 & eastern side of central upland & \\
\hline 12 & $\ldots \ldots \ldots$ & \\
\hline & in & \\
\hline 13 & $\ldots \ldots \ldots$ & \\
\hline & tion $\ldots \ldots \ldots \ldots \ldots \ldots$ & \\
\hline 14 & tionships & 41 \\
\hline 14 & $\ldots \ldots \ldots$ & 41 \\
\hline 15 & Formation $\ldots \ldots \ldots$ & 41 \\
\hline 1 & $\ldots \ldots$ & 41 \\
\hline $1:$ & ogy and type section $\ldots \ldots \ldots$ & 41 \\
\hline 16 & $\ldots \ldots \ldots \ldots$ & 44 \\
\hline 16 & . & 44 \\
\hline & & \\
\hline 2 & ind absolute age estimates $\ldots \ldots$ & 45 \\
\hline 2 & $\ldots \ldots \ldots$ & 45 \\
\hline 28 & Holocene dep & 46 \\
\hline 2 & on complex $\ldots \ldots \ldots \ldots$ & 46 \\
\hline 2 & & 46 \\
\hline 29 & reologic history _. & 47 \\
\hline $30>>>$ & urface & 47 \\
\hline 3 & $\operatorname{Pr}$ & 47 \\
\hline 3 & t complex $\ldots .$. & 49 \\
\hline 3 & $\ldots \ldots$ & 49 \\
\hline 3 & bordering & \\
\hline 3. & & 50 \\
\hline 3 & Paludal and eolian deposits of late Wisconsin age & \\
\hline 32 & Holocene transgressiv & \\
\hline 32 & 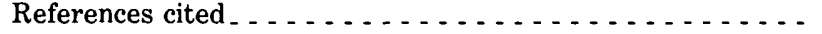 & \\
\hline
\end{tabular}




\section{ILLUSTRATIONS}

[Plates in pocket]

Plate

1. Generalized geomorphic map of the southern Delmarva Peninsula, Va. and Md., and map showing generalized topography of the Chesapeake-Delaware lowland and adjacent Coastal Plain areas.

2. Generalized geologic map and cross sections and map showing locations of U.S. Geological Survey boreholes and water test wells, southern Delmarva Peninsula, Va. and Md.

FIGURE

1. Map showing area of study in southeastern Virginia and southernmost Maryland and its relationship to the Chesapeake Bay and the Atlantic Ocean . . . . . . . . . . . . . . . . . . . . . . . . .

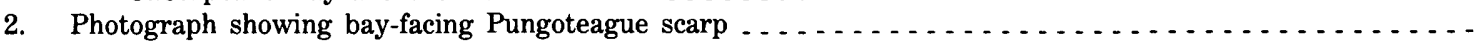

3. Correlation chart of upper Tertiary rock-stratigraphic and hydrologic units in the southern and central Delmarva

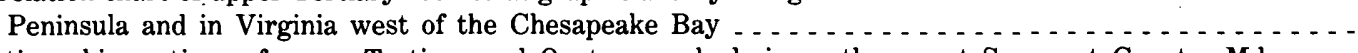

4. Stratigraphic sections of upper Tertiary and Quaternary beds in southernmost Somerset County, Md ....

5. Stratigraphic section of Tunnels Mill Member of the Yorktown Formation and the overlying Kent Island Forma-

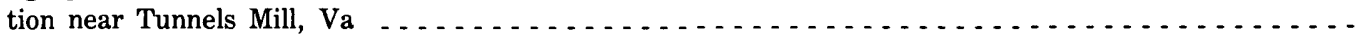

6. Section of Tunnels Mill Member and upper shelly sand member of the Yorktown Formation and the overlying Accomack Member of the Omar Formation . . . . . . . . . . . . . . . . . . . . . . . . . .

7. Correlation of Pleistocene rock-stratigraphic units in the southern and central Chesapeake Bay area, Virginia

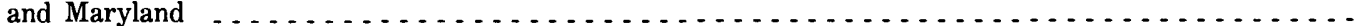

8. Borehole section showing the Accomack Member of the Omar Formation and underlying beds at T's Corner, Va

9. Map of the erosion surface on the top of the Tertiary beds, southern Delmarva Peninsula area ........ 10-15. Photographs showing:

10. Lagoonal mud and sand of facies $\mathrm{C}$ of the Accomack Member of the Omar Formation overlain by crossbedded barrier sands in borrow pit at Assawoman, $\mathrm{Va}$. . . . . . . . . . . . . . . . . . . .

11. Burrowed, crossbedded, medium to coarse pebbly sand of facies $\mathrm{E}$ of the Accomack Member of the Omar Formation in borrow pit near Accomac, $\mathrm{Va}$. . . . . . . . . . . . . . . . . . . .

12. Clean, crossbedded sands of the Accomack Member of the Omar Formation in roadcut near Horntown, $\mathrm{Va}$ -

13. Moderately well sorted, fine to medium planar-bedded sand of facies $F$ of the Accomack Member of the Omar Formation exposed in borrow pit near Persimmon Point, Va _ . . . . . . . . . . . . . . . . .

14. Close-up of outcrop of facies $F$ of the Accomack Member of the Omar Formation at Persimmon Point showing alternating laminae of black heavy minerals and pale gray quartz sand typical of swash-zone deposits -

15. Large adult forms of Spisula solidissima in shelly sands of the Accomack Member of the Omar Formation in an excavation near Accomac, $\mathrm{Va}$

16. Cross section showing lateral and vertical facies succession in the Accomack Member of the Omar Formation in northern Accomack County, Va

17.

Generalized stratigraphic sections comparing vertical facies succession and depositional environments of the Accomack Member in northern and southern parts of Accomack County, Va . . . . . . . . . . . . . . .

18. Cross section showing distribution, lithology, and thickness of lithic units forming the Pleistocene fill of the Eastville paleovalley, southern Northampton County, Va . . . . . . . . . . . . . . . . . . . . . . .

19. Photograph of highly leached, crossbedded sands of the Butlers Bluff Member of the Nassawadox Formation in wavecut cliffs at Butlers Bluff locality, southern Northampton County, Va . . . . . . . . . . . . . . . . .

20. Photograph of Ophiomorpha burrow and shell ghosts in the Butlers Bluff Member of the Nassawadox Formation

21. Photograph of type section of the Occohannock Member of the Nassawadox Formation in low cliffs on north side of Occohannock Creek near Bell Haven, Va _. . . . . . . . . . . . . . . . . . . . . . . . . .

Stratigraphic column of type section of Joynes Neck Sand and underlying formations at borehole locality A-15 in

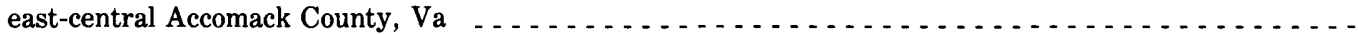

Sketch map showing relationship of Bell Neck sand-ridge complex to older geomorphic features of the southern Delmarva Peninsula

24.

25.

Stratigraphic column of type section of the Wachapreague Formation and upper part of the Yorktown Formation

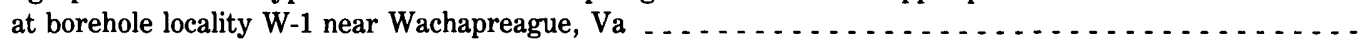

26. Paleogeographic maps showing development of the southern Delmarva Peninsula during late Quaternary time . 


\title{
STRATIGRAPHIC AND GEOMORPHIC FRAMEWORK OF UPPERMOST CENOZOIC DEPOSITS IN THE SOUTHERN DELMARVA PENINSULA, VIRGINIA AND MARYLAND
}

\author{
By R. B. MIXON
}

\section{ABSTRACT}

The surface of the southern Delmarva Peninsula is a flat to gently rolling central ridge or upland bordered on both east and west by low plains or terraces that slope very gently toward the Chesapeake Bay and the Atlantic Ocean. Surfaces of the less dissected parts of both the upland and the lowland plains are inferred to be remnants of the original depositional surfaces, which formed during emplacement of the directly underlying marginal-marine and fluvialestuarine deposits.

The surface and shallow subsurface deposits of the study area include (1) a 5- to 200-ft-thick (2- to 60-m-thick) mantle of unconsolidated sand, gravel, silt, clay, and peat of Quaternary age that unconformably overlies (2) several hundred feet of more consolidated upper Tertiary glauconitic sand and clay-silt. The contact between the two sedimentary systems is generally marked by a lag gravel or peat at the base of the Quaternary beds and by differences in color and compaction. The erosion surface at the top of the Tertiary section is commonly gently undulating with about 10-30 ft (3-9 m) of local relief; however, contouring of the erosion surface shows major paleotopographic lows (paleovalleys) trending southeastward across the northern, central, and southern parts of the study area. The largest buried paleovalley, which crosses the peninsula near Eastville, Va, was eroded to depths of $165 \mathrm{ft}(50 \mathrm{~m})$ below present sea level and is be lieved to mark a main drainageway of the ancestral SusquehannaPotomac river system.

The upper Tertiary strata, which form the core of the peninsula, dip gently southeastward toward the Baltimore Canyon trough. The lithology and the fairly diverse molluscan and ostracode assemblages of these beds indicate shallow-shelf depositional environments and enable correlation with the upper Miocene to middle Pliocene Eastover and Yorktown Formations, which crop out west of the Chesapeake Bay. However, the thick, sideritic clay-silts and pebbly sands of the Tunnels Mill Member of the Yorktown Formation are interpreted to be the distal part of a southeastward-prograding delta.

The Quaternary sediments that mantle the mainland part of the peninsula consist largely of marginal-marine and estuarine deposits emplaced during high stands of the sea associated with one or more late Pleistocene interglacial stages. The older Pleistocene depositional sequences of the central upland consist of two barrier-spit or barrierisland sediment complexes that were constructed southwestward partly across the mouth of an ancestral Chesapeake Bay. Beds of the older barrier-spit complex, herein named the Accomack Member of the Omar Formation, underlie the higher, more dissected upland area north of the Ames Ridge shoreline. The Accomack beds, which are as much as $80 \mathrm{ft}(24 \mathrm{~m})$ thick, include seven interfingering and overlapping sedimentary facies very similar to those of the modern transgressive barrier-lagoon system of the Delmarva coastal zone. Beds of the younger spit complex, named the Nassawadox Formation, underlie the narrow, relatively flat upland south of the Ames Ridge shoreline and the Franktown plain, which is adjacent to and west of the upland. The Nassawadox Formation consists of the Stumptown Member, composed of the gravelly, sandy, and silty fill of the Eastville paleovalley; the overlying Butlers Bluff Member, consisting of cleaner, better sorted, fine to coarse, crossbedded gravelly sand interpreted to represent barrier-spit and nearshore-shelf environments, and the Occohannock Member, composed of fine to medium, massive to horizontally bedded sand interpreted to have been deposited in a large bay or estuary behind the Nassawadox barrier. Both the Acco mack and the Nassawadox beds are characterized by a warmtemperate flora and fauna.

Sandy and gravelly deposits of the Kent Island Formation underlie the broad, bayward-sloping Occohannock lowland that borders the central upland on the west. The lithology of the Kent Island and the geomorphic setting indicate that the unit represents sandy bottom deposits of an ancestral Chesapeake Bay. Borehole sections in the southern part of the Kent Island terrane show that southward the unit becomes finer grained and better sorted and grades downward without a perceptible break into shelly sands equivalent to the Butlers Bluff Member of the Nassawadox Formation.

Marginal-marine deposits bordering the eastern side of the central upland include the Joynes Neck Sand and the Wachapreague Formation, which underlie, respectively, the seaward-sloping Metomkin plain and the low ridges and swales of the adjacent coastal lowland 
(the Bell Neck sand-ridge complex). The fining-upward Joynes Neck Sand is a fine to coarse sand and sandy gravel, as much as $30 \mathrm{ft}(10 \mathrm{~m})$ thick, interpreted to be a transgressive shelf-plain deposit and thought to be equivalent, in part, to the Nassawadox Formation. The coarsening-upward Wachapreague Formation, as much as $40 \mathrm{ft}(12 \mathrm{~m})$ thick, includes a lower member of fossiliferous, muddy, fine sand of shallow-shelf origin and an upper member of relatively clean, gravelly sand that forms a regressive sequence of at least 11 barrier ridges. Molluscan and ostracode assemblages composed of both coldtemperate and warm-temperate species and pollen assemblages containing abundant spruce and pine indicate that the Wachapreague beds were deposited during cooling climatic conditions. Shell material from the Wachapreague beds yields a radiocarbon age of greater than 33,000 years B.P. and an amino-acid-racemization age estimate of 82,000 years B.P., which are comparable to uranium-thorium and amino-acid-racemization ages from the Butlers Bluff Member of the Nassawadox Formation. These age estimates suggest that the Wachapreague beds represent the regressive phase of a Nassawadox transgressive-regressive cycle rather than a separate major transgression in mid-Wisconsin time.

\section{INTRODUCTION}

The Delmarva Peninsula is the vast sandy lowland in the Middle Atlantic Coastal Plain that lies between the Chesapeake Bay on the west and the Delaware Bay and Atlantic Ocean on the east (fig. 1). Because of increasing interest in the geology of the outer Atlantic Coastal Plain, the U.S. Geological Survey (USGS) has recently undertaken projects to investigate and map the sandy and gravelly upper Cenozoic deposits that mantle the central and southern parts of the peninsula. The principal goals include (1) erecting a geomorphic and stratigraphic framework for the surficial deposits, (2) determining the age and origin of the Chesapeake and Delaware estuaries, and (3) interpreting the late Cenozoic geologic history of the Delmarva Peninsula and surrounding region.

This study focuses on the surficial sediments of late Pleistocene age that form the narrow, mainland part of the Delmarva Peninsula in Virginia and southernmost Maryland (fig. 1). The underlying upper Miocene and Pliocene beds and the erosion surface at the top of the Tertiary were also studied in reconnaissance to provide data on the depositional and erosional history of the peninsula area in latest Tertiary and early Quaternary time. A companion study of the central Delmarva Peninsula by J. P. Owens and C. S. Denny discusses the surface and shallow subsurface geology of adjacent parts of Maryland and southern Delaware (Owens and Denny, 1978, 1979a,b; Denny and Owens, 1979; Denny and others, 1979).

The upper Pleistocene beds of the southern Delmarva Peninsula, discussed herein, consist chiefly of sand, gravel, silt, and clay deposited in marginal-marine and estuarine environments during interglacial high stands of the sea. Sediment thickness ranges from about $5 \mathrm{ft}$ $(2 \mathrm{~m})$, observed locally in southwesternmost Maryland, to as much as $200 \mathrm{ft}(60 \mathrm{~m})$ in southern Northampton County, Va. The surface of the deposits is characterized by coastwise terrace plains that step down toward the Chesapeake Bay and the Atlantic Ocean (pl. 1). The terrace plains are separated by low, linear scarps that delineate ancient marine and estuarine shorelines and record fluctuations of sea level in late Pleistocene time. The abundantly fossiliferous nature of the Pleistocene beds and the thicker, more complete sedimentary sections (compared with those of nearby upper Pleistocene terranes) make the southern Delmarva Peninsula one of the better places to establish a lithostratigraphic and biostratigraphic framework for the upper Pleistocene of the Chesapeake Bay area.

Except for a reconnaissance study of the groundwater resources of Accomack and Northampton Counties (Sinnott and Tibbitts, 1968), almost nothing was known about the Pleistocene geology of the Virginia part of the Delmarva Peninsula prior to this investigation. Thus the initial efforts for this study were directed toward (1) describing the lithology and sedimentary structures of strata exposed in sand and gravel pits, roadcuts, and natural outcrops, (2) identifying mappable sedimentary facies and interpreting their depositional environments on the basis of lithology, structures, and faunal assemblages, and (3) ascertaining the lateral and vertical facies successions that characterize different parts of the study area. Subsequently, to determine the three-dimensional shapes and distribution of sedimentary facies, 89 boreholes were drilled to an average depth of $66 \mathrm{ft}(20 \mathrm{~m})$. Almost all these boreholes penetrated the Pleistocene beds and bottomed in the underlying, more consolidated uppermost Tertiary strata. In addition to providing lithologic data for the unexposed middle and lower parts of the Pleistocene section and the upper Tertiary beds, the borings sampled fossiliferous strata containing wellpreserved mollusks, ostracodes, foraminifers, diatoms, and pollen. These fossil assemblages are the basis for much of the paleoenvironmental interpretation discussed herein.

The surface and shallow subsurface studies described above have defined geomorphic units and rock-stratigraphic units of formation and member rank and have made possible the construction of maps and cross sections to show the lateral and vertical relationships of lithic units (pls. 1, 2). In turn, the knowledge of the spatial relationships of lithic units, combined with a knowledge of depositional environments and relative ages, permits reconstruction of the late Pleistocene geologic history of the southern Delmarva Peninsula. 


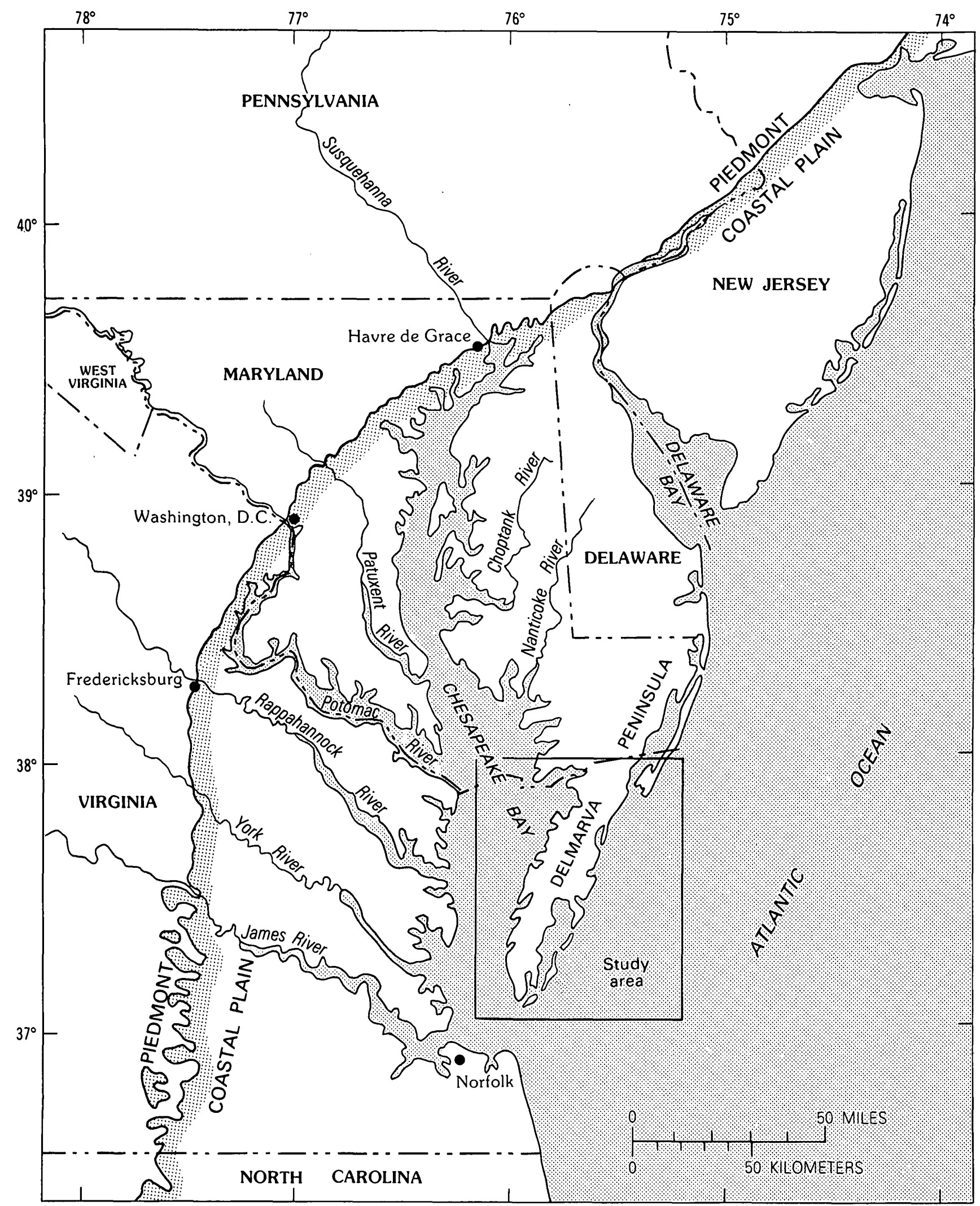

FIGURE 1.-Location of study area in southeastern Virginia and southernmost Maryland and its relationship to the Chesapeake Bay and the Atlantic Ocean. 


\section{AREA OF STUDY}

The area of the present study is the narrow, southern part of the Delmarva Peninsula, bounded by $37^{\circ}$ and $38^{\circ} \mathrm{N}$. latitude and lying almost entirely within Virginia. A small strip of southernmost Maryland, extending from the mouth of the Pocomoke River westward to the port city of Crisfield, lies south of $38^{\circ} \mathrm{N}$. latitude and is included in the study area (pl. 1). A companion study has investigated and mapped much of the Maryland and Delaware parts of the Delmarva Peninsula between $38^{\circ}$ and $39^{\circ} \mathrm{N}$. latitude (Owens and Denny, 1978, 1979a,b). Field investigations for this study have been confined almost entirely to the mainland part of the peninsula, which separates the broad expanse of the lower Chesapeake Bay from the Atlantic Ocean. Here the peninsula is a sandy lowland, which consists mostly of fairly well drained, intensively cultivated agricultural land and open, loblolly-pine woodlands. However, several of the flatter, more poorly drained interfluve areas along the northwest side of the peninsula include large tracts of swampland. Along the margin of Chesapeake Bay, especially in the area of the Pocomoke and Tangier Sounds, the mainland is fringed by extensive brackish to freshwater marshes. On its ocean side, the mainland is bordered by a Holocene barrier-lagoon complex, as much as $8 \mathrm{mi}(13 \mathrm{~km})$ wide, which comprises extensive salt marshes, muddy tidal flats, shallow bays, and low sandy barrier islands.

\section{PREVIOUS INVESTIGATIONS}

Most previous geologic investigations concerned in whole or in part with the central and southern Delmarva Peninsula have been subsurface studies focusing on the area's ground-water resources and petroleum potential (Rasmussen and Slaughter, 1955; Hansen, 1966, 1967; Sinnott and Tibbitts, 1968; Maher, 1971; Brown and others, 1972; Weigle, 1972, 1974; Robbins and others, 1975). Of the above studies, only that of Sinnott and Tibbitts was involved principally with the Virginia part of the peninsula. These authors described the general lithology, stratigraphy, and water-bearing characteristics of the Mesozoic and Cenozoic beds underlying the southern Delmarva Peninsula and presented cross sections correlating these beds with equivalent stratigraphic sections west of the Chesapeake Bay (see Sinnott and Tibbitts, 1968, p. 15-19 and 70-74, pls. 1, 2). However, the Pleistocene deposits, included in the "Columbia Group, undifferentiated," are discussed only briefly. Prior to this. study and that of Owens and Denny (1979b), the surficial Pleistocene stratigraphy and geomorphology of this area had been studied main- ly in Delaware (Jordan, 1962, 1974; Jordan and others, 1967).

\section{ACKNOWLEDGMENTS}

I wish to thank Charles S. Denny and James P. Owens, USGS, for their interest and encouragement during the southern Delmarva field studies. Appreciation is also expressed to the following members of the USGS: Joseph E. Hazel, Rick M. Forester, Thomas M. Cronin, and Thomas G. Gibson, who made identifications and environmental interpretations of the ostracode and foraminifer assemblages in the Pleistocene and upper Tertiary strata; Blake W. Blackwelder, Lauck W. Ward, and Druid Wilson, who studied the mollusks; Leslie A. Sirkin and Thomas A. Ager, who identified and interpreted the pollen assemblages; Meyer Rubin and Elliott C. Spiker, who dated shell, wood, and peat samples from mainland and barrier-island localities; and Barney J. Szabo, who obtained uranium-isotope age estimates from samples of coral, Mercenaria, and Ostrea. John F. Wehmiller, University of Delaware, and Daniel F. Belknap, University of South Florida, provided amino-acid-racemization data from mollusks. I also wish to thank William $\mathbf{R}$. Raspet, William S. Kirk, Nicholas Lampiris, and Steve Pearlman for their able assistance in the field.

Special thanks are due to Gerald H. Johnson, College of William and Mary, for stimulating discussions in the field and helpful criticism of the manuscript.

\section{GEOMORPHOLOGY}

\section{DELMARVA PENINSULA AND CHESAPEAKE- DELAWARE LOWLAND}

The Delmarva Peninsula is the part of the Atlantic Coastal Plain that lies between the Chesapeake Bay on the west and the Delaware Bay and Atlantic Ocean on the east (fig. 1). The peninsula includes most of the State of Delaware and large areas of eastern Maryland and Virginia-hence the name Delmarva. Together, the Delmarva Peninsula and the submerged Coastal Plain beneath the Chesapeake and Delaware Bays constitute the main part of a vast topographic basin that extends from the Atlantic Coast inland almost to the Fall Line (pl. 1). This basin, herein informally called the Chesapeake-Delaware lowland, includes low-lying areas in southern New Jersey adjacent to the east side of Delaware Bay and in Maryland and Virginia bordering the west side of Chesapeake Bay. 
The gently rolling surface of the ChesapeakeDelaware lowland generally ranges in altitude from a maximum of about $80 \mathrm{ft}(24 \mathrm{~m})$ above sea level in the higher, north-central part of the Delmarva Peninsula to a minimum of about $30 \mathrm{ft}(9 \mathrm{~m})$ below present sea level over most of the submerged part of the lowland. However, in the deeper, central parts of the Chesapeake and Delaware Bays, narrow fluvial channels cut during low stands of the sea associated with glacial maxima are $200 \mathrm{ft}(61 \mathrm{~m})$ or more below sea level (Hack, 1957). Subsequently, during higher sea levels, these deep channels have been partially filled by alluvial and estuarine deposits. The Chesapeake-Delaware lowland is flanked on each side by deeply dissected Coastal Plain uplands, whose relatively flat interfluve areas slope upward from about $100 \mathrm{ft}(30 \mathrm{~m})$ or less near the margin of the lowland to $280 \mathrm{ft}(85 \mathrm{~m})$ or more at the Fall Line in Virginia and Maryland and $360 \mathrm{ft}(110 \mathrm{~m})$ in the New Jersey Highland.

During the Quaternary and at least part of the late Tertiary, the Chesapeake-Delaware lowland was the drainageway for several of the larger, east-flowing rivers of the central Appalachian region, including the Delaware, the Susquehanna, the Potomac, and the James. Of these rivers the Susquehanna has by far the largest drainage basin, encompassing about $27,000 \mathrm{sq}$ $\mathrm{mi}(70,000 \mathrm{sq} \mathrm{km})$ of the Appalachian Plateau, Valley and Ridge, Blue Ridge, Piedmont, and innermost Coastal Plain. The Potomac drainage basin, totaling about $11,560 \mathrm{sq} \mathrm{mi}(30,000 \mathrm{sq} \mathrm{km})$, is second in size. The detrital sand and gravel sheets that constitute the surficial deposits of the Delmarva Peninsula and adjacent parts of the Chesapeake-Delaware lowland are thought to be derived mainly from the Delaware, Susquehanna, and Potomac River drainage basins.

The sandy and gravelly surficial deposits of the Chesapeake-Delaware lowland and equivalent beds of the main tributary river valleys are inset well below the level of the older, deeply dissected Cenozoic strata of the adjacent Coastal Plain upland. This relationship and the apparent lack of major fault offset of Cretaceous and Tertiary stratigraphic units coincident with the trend of lowland-upland boundaries indicate that the Chesapeake-Delaware lowland is mainly an erosional feature. The deepening and widening of the lowland by processes such as fluvial downcutting, slumping, and colluviation took place more rapidly during glacially controlled times of lower sea level. During higher sea levels, shoreline retreat caused by wave erosion was, and still is, an important erosional process. Tectonism, involving downwarping of the inner edge of the Coastal Plain strata relative to the Piedmont crystalline rocks, was important mainly in controlling the position of the northeast-trending lowland margin in the upper Chesa- peake and upper Delaware Bay areas (see pl. 1; Mixon and Newell, 1977). The downwarping of the inner edge of the Coastal Plain also appears to have strongly influenced the location of the Fall Line and the southwestward deflections of the Potomac, the Susquehanna, and the Delaware Rivers in the area just east of the Fall Line.

\section{SOUTHERN DELMARVA PENINSULA}

In the study area, the surface of the Delmarva Peninsula comprises (1) a flat to gently rolling central ridge or upland bordered on both east and west by (2) low plains or terraces that slope very gently toward the Chesapeake Bay and the Atlantic Ocean (see pl.1). The upland, which extends the length of the peninsula, is as much as $4 \mathrm{mi}(6.5 \mathrm{~km})$ in width and about $35-60 \mathrm{ft}(11-18 \mathrm{~m})$ in altitude. The terrace plains are as much as $7 \mathrm{mi}(11 \mathrm{~km})$ in width and range from sea level to about $25 \mathrm{ft}(8 \mathrm{~m})$ in altitude. The plains are separated from the upland by linear to slightly curving scarps that are interpreted as relict marine and estuarine shorelines (fig. 2).

The surfaces of the less dissected parts of both the upland and the adjacent lowland plains are inferred to be remnants of the youngest depositional surfaces that formed during emplacement of the underlying marginalmarine and fluvialestuarine deposits (see also Thom, 1967; Colquhoun, 1969; Mixon and Pilkey, 1976). Thus, the land surface of much of the southern Delmarva Peninsula is believed to closely approximate the original depositional surfaces of late Pleistocene shelf-plains, barriers, lagoons, estuaries, and fluvial point bars and swales. The altitude of the depositional surfaces, the degree of dissection, the maturity of soils, and the truncating relationships between surfaces and scarps are criteria used to determine the relative ages of geomorphic map units and to interpret the geologic history of the underlying deposits.

\section{STRATIGRAPHY}

\section{UPPER TERTIARY DEPOSITS}

\section{EASTOVER FORMATION}

The oldest lithic unit sampled for this study consists of upper Miocene shelly sand and silt encountered in shallow borings in the vicinity of Crisfield, Md. The molluscan assemblage obtained from these beds indicates a correlation with the Cobham Bay Member, the upper member of the Eastover Formation of the Chesapeake Group, which crops out in the Virginia Coastal Plain west of the Chesapeake Bay (see fig. 3; 

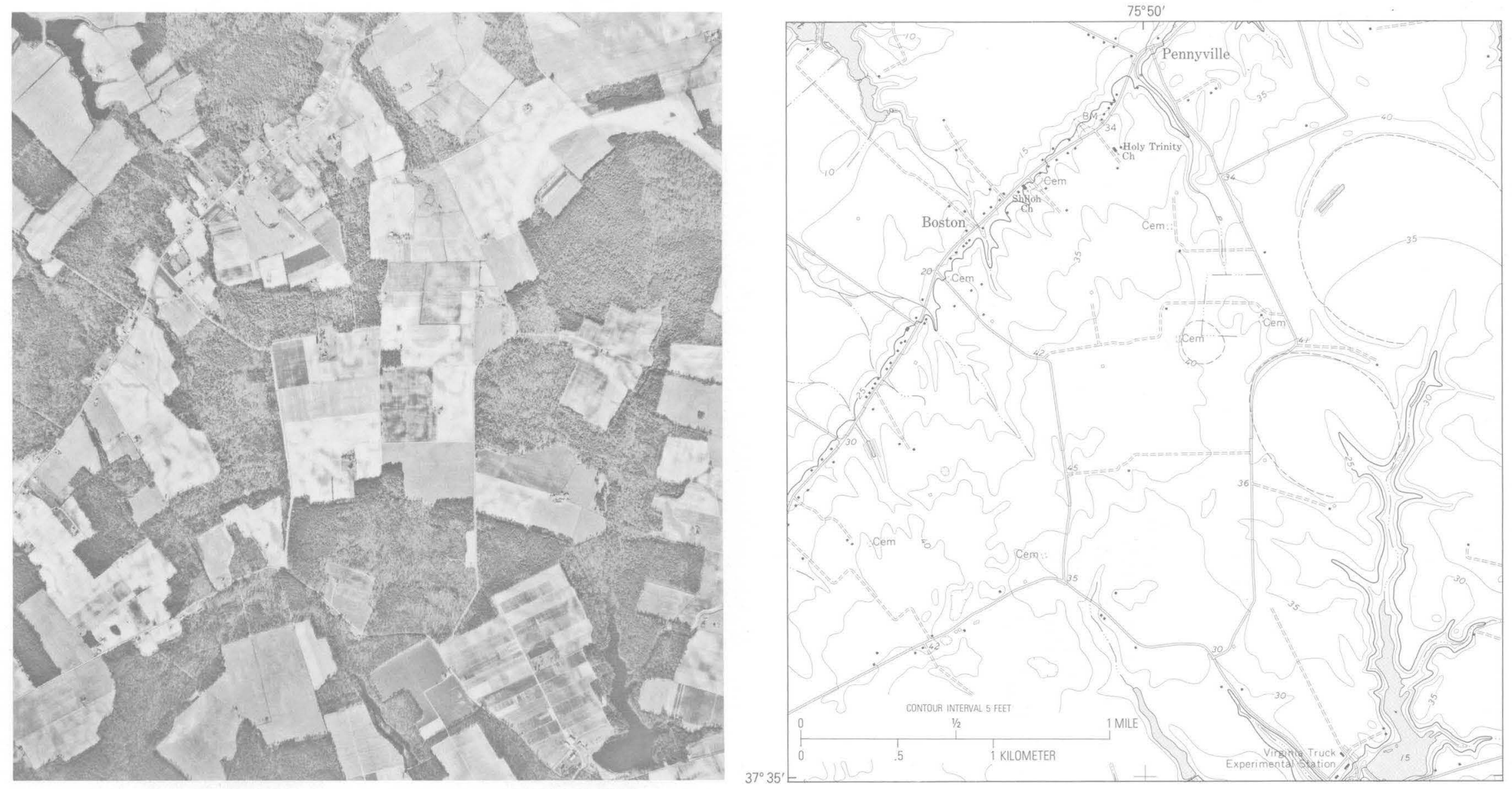

FIGURE 2.-Bay-facing Pungoteague scarp extending across upper left of aerial photograph and topographic map is relict shoreline of ancestral Chesapeake Bay (pl. 1). Bayside Roa closely parallels scarp crest. Mottled texture and elliptical rims of Carolina Bays southeast of scarp typify gently rolling surface of upland area. The more uniformly textured, bayward-dipping surface northwest of searp is floor of ancestral Chesapeake Bay. 


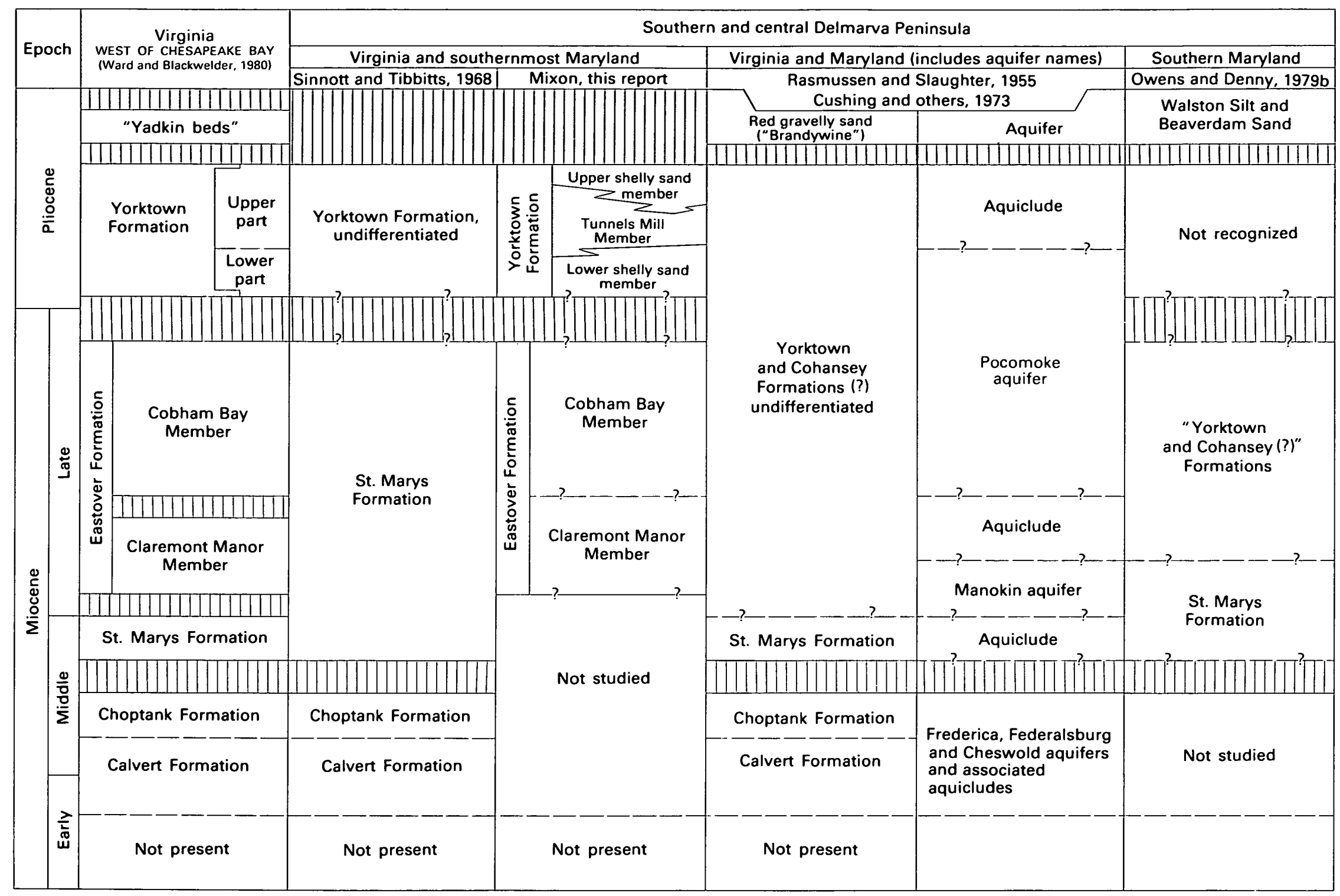

FIGURE 3.-Correlation of upper Tertiary rock-stratigraphic and hydrologic units in the southern and central Delmarva Peninsula and in Virginia west of the Chesapeake Bay. The term "aquiclude," used by Rasmussen and Slaughter (1955), has been replaced by the phrase "confining bed." 
Ward and Blackwelder, 1980). Only the truncated, upper part of the Eastover Formation was penetrated by our borings; thus, the brief description that follows is applicable mainly to that part of the formation.

\section{LITHOLOGY}

The principal lithology is greenish-gray, clayey, silty, and shelly quartz sand. The sand fraction is chiefly fine to very fine but includes some medium to coarse sand and sparse pebbles of quartz and phosphate. The percentage of shell material is sufficient in some beds to classify the sediment as a shell hash or coquina.

\section{STRATIGRAPHIC RELATIONSHIPS}

In the vicinity of Crisfield, beds of the Eastover Formation are unconformably overlain by upper Pleistocene sand of the Kent Island Formation, 10-20 ft (3-6 m) thick (pl. 2; fig. 4). About $4 \mathrm{mi}(6.5 \mathrm{~km})$ east of Crisfield, at the Indian Hammock locality, the top of the Eastover Formation is about $40 \mathrm{ft}(12 \mathrm{~m})$ below sea level. Here the Eastover beds are unconformably overlain by clayey and silty sand that is possibly equivalent to the Yorktown Formation of middle Pliocene age. The contact between the two formations is abrupt, the basal gravelly sand of the Yorktown (?) beds overlying micaceous clay-silt and shelly sand of the Eastover. If the very shelly Eastover sands penetrated at depths of $-25 \mathrm{ft}(-7.5 \mathrm{~m})$ and $-49 \mathrm{ft}(-15 \mathrm{~m})$ in the boreholes in north Crisfield (loc. C-4) and Indian Hammock (loc. C-2), respectively, are equivalent, the eastward component of dip of the Eastover beds across the northern part of the Crisfield 7.5-min quadrangle is at least $6 \mathrm{ft} / \mathrm{mi}(1 \mathrm{~m} / \mathrm{km})$ (fig. 4). This calculated dip component compares favorably with the regional $8 \mathrm{ft} / \mathrm{mi}(1.5 \mathrm{~m} / \mathrm{km})$ true dip to the southeast reported by Rasmussen and Slaughter for upper Tertiary beds in Somerset County that were included in the "Yorktown and Cohansey Formations(?) undifferentiated" (see Rasmussen and Slaughter, 1955, p. 93, 101).

FAUNA

Small, well-preserved molluscan assemblages and an unidentified bryozoan were obtained from borehole sections near McCready Hospital in the northern outskirts of Crisfield (loc. C-4) and at the community of Indian Hammock (loc. C-2), about $4 \mathrm{mi}(6.5 \mathrm{~km})$ east of Crisfield. Faunal lists for each locality (Blackwelder and Ward, written commun., 1974) are as follows:
Chesapecten? sp. (fragment)

Corbicula sp. (fragment, common)

Mactra sp. (fragment, heavy form)

Nuculana sp. (similar to an Eastover Formation form)

Mercenaria sp. (fragment)

Pleiorhytis sp. (fragment)

LOCALITY C-2

Glycymeris sp. (Eastover Formation form)

Spisula sp. cf. S. rappahannockensis Gardner

Lirophora sp. (Eastover Formation form)

Cyclocardia sp.

Arca sp. (fragment)

Ostrea sp. (fragment)

Astarte sp. cf. A. rappahannockensis Gardner

In addition to the fossils from our boreholes, the following mollusks of Eastover age were noted in a reexamination of samples from the 130 - to $150-\mathrm{ft}(40-$ to 46-m) interval in the old artesian water well at Crisfield, which was drilled in 1894 by Burton Water Company (Blackwelder and Ward, written commun., 1974):

Glycymeris virginiae Wagner

Cyclocardia sp. cf. C. granulata (Say)

Lirophora dalli Olsson

Ostrea sp. (predecessor to $O$. compressirostra)

Turritella sp. aff. T. plebia Say

Isognomon $\mathrm{sp}$.

Lunatia sp. (large form)

Chesapecten middlesexensis (Mansfield)

Mesodesma sp.

\section{PALEOENVIRONMENT}

Except for the presence of Corbicula, the above molluscan assemblages indicate normally saline, shallow-shelf depositional environments. Modern species of Corbicula live in fresh to brackish water; thus, the presence of Corbicula in the assemblage from the McCready Hospital locality (C-4) suggests either that the paleoenvironment was less saline than normal or that the Corbicula were transported to the shelf from nearby rivers or estuaries.

\section{AGE AND CORRELATION}

The Glycymeris, Lirophora, Spisula, and Astarte from the Indian Hammock locality (borehole $\mathrm{C}-2$ ) indicate a late Miocene age for the enclosing beds and a correlation with the Cobham Bay Member of the Eastover Formation (Blackwelder and Ward, written commun., 1975). The molluscan assemblage from the Crisfield locality 

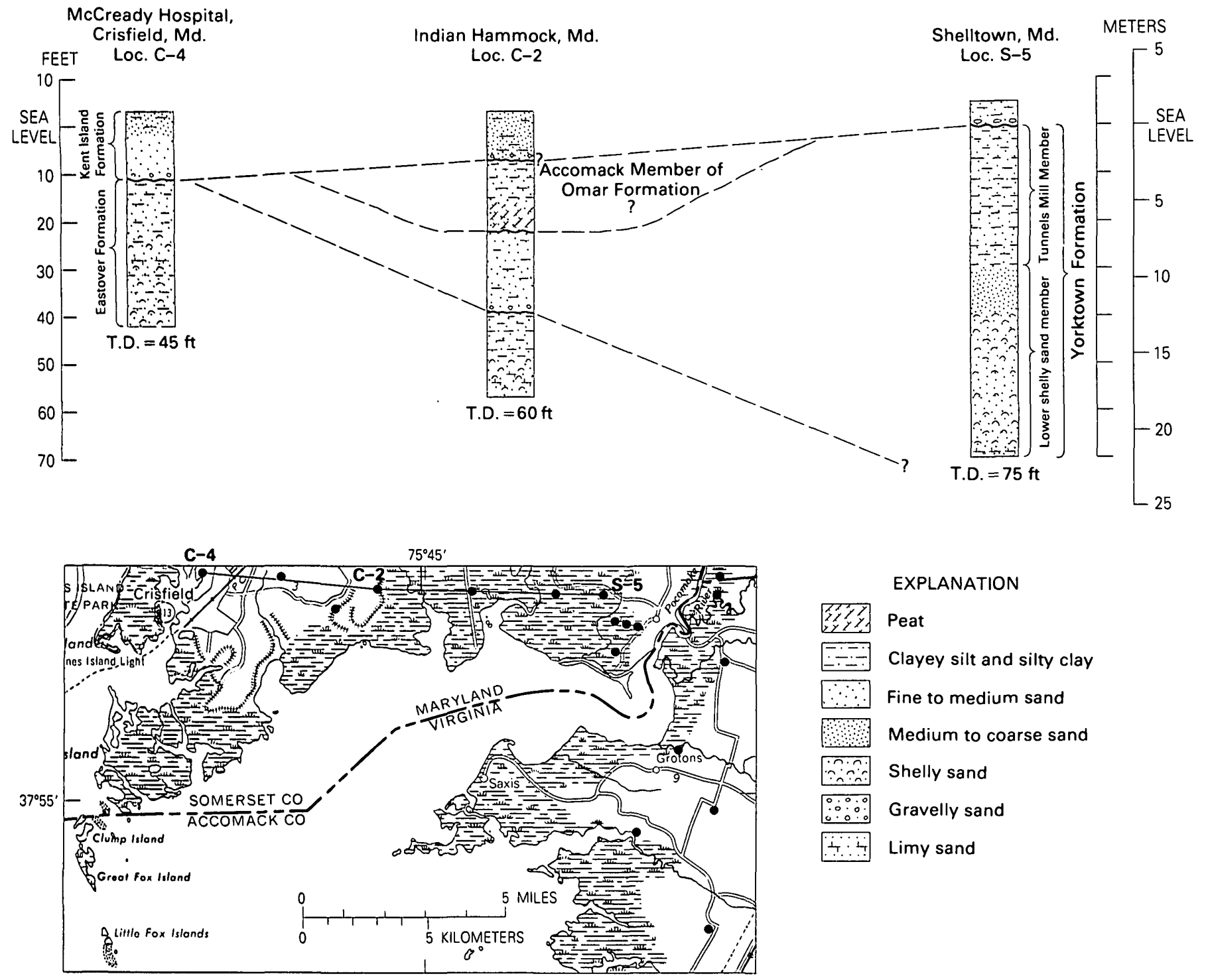

EXPLANATION
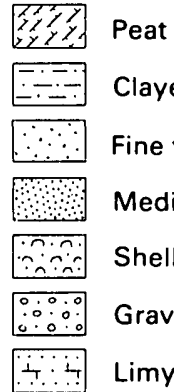

Clayey silt and silty clay

Fine to medium sand

Medium to coarse sand

Shelly sand

Gravelly sand

Limy sand

Index map showing line of cross section

FIGURE 4.-Tentative correlation of uppermost Tertiary and Quaternary stratigraphic sections in southernmost Somerset County, Md. Regional dip of Eastover and Yorktown beds is to the southeast at about 6-8 ft/mi (1-1.5 m/km). Strata of the Kent Island Formation are flat-lying or dip very gently toward the Chesapeake Bay. Line of cross section and borehole locations C-2, C-4, and S-5 are shown on plate 2.

(borehole C-4) does not permit an age designation for the sampled horizons. However, the lithic similarity of the Tertiary beds at both localities and the southeast regional dip suggest that the beds are correlative. If the beds are indeed correlative, the lack of duplication of species in boreholes $\mathrm{C}-2$ and $\mathrm{C}-4$ is somewhat puzzling. The mollusk species present at the two localities are known to have existed together in Eastover Formation time; therefore, the lack of species duplication may have resulted from incomplete sampling or from the rapid vertical and horizontal variation in assemblages that is known to occur in the Eastover beds east of the Chesapeake Bay.

According to Blackwelder and Ward (written commun., 1974), the Glycymeris virginiae and Lirophora dalli in the Crisfield water well samples are of unquestioned late Miocene age and, in the central Virginia Coastal Plain to the west of Chesapeake Bay, are restricted to the lower member (Claremont Manor Member) of the Eastover. 


\section{RELATIONSHIP TO HYDROLOGIC UNITS}

Beds constituting the lower $31 \mathrm{ft}(9.5 \mathrm{~m})$ of the stratigraphic section in borehole $\mathrm{C}-4$ in north Crisfield, herein tentatively assigned to the Eastover Formation, have been included in the "upper aquiclude" and "Pocomoke aquifer" of the "Yorktown and Cohansey Formations (?)" undifferentiated, of Rasmussen and Slaughter (see Rasmussen and Slaughter, 1955, table 41, logs for wells Som-Ec 30 and Som-Ec 33; Hansen, 1967, table 8). A late Miocene age for the "Pocomoke aquifer" beds farther northeast in Somerset County and a correlation with the "St. Mary's Formation of Virginia" (redefined as the Eastover Formation by Ward and Blackwelder, 1980) have also been suggested by Owens and Denny (1979b, p. A10). The interpretation proposed in this report differs from that of Owens and Denny (1979b) in that the upper part of the "Pocomoke aquifer" in downdip areas east of the Crisfield quadrangle is considered to be part of the Yorktown Formation of middle Pliocene age. The problem of the ages of the "Pocomoke aquifer" beds and the clays and silts of the overlying confining bed is discussed in more detail in the section describing the Yorktown Formation.

\section{YORKTOWN FORMATION}

\section{PREVIOUS INVESTIGATIONS}

In the subsurface of much of the southern Delmarva area, the Miocene Eastover Formation is directly overlain by a sequence of glauconitic sand, silt, and clay of early Pliocene age. These beds appear to be thin or absent near Crisfield in the westernmost part of the study area but thicken to the east and south to $150 \mathrm{ft}(46 \mathrm{~m})$ or more along the eastern margin of the peninsula. The presence of a thick section of Pliocene beds in Northumberland County, Va., directly across the Chesapeake Bay to the southwest, indicates that the thinness or absence of the Pliocene in the Crisfield area is due to erosion and to truncation by younger beds rather than to nondeposition. On the basis of their fossil fauna and stratigraphic position, the Pliocene beds in the Delmarva area are correlated with the Yorktown Formation of the Chesapeake Group, which is extensively exposed in the Virginia Coastal Plain west of the Chesapeake Bay (Sinnott and Tibbitts, 1968). The lithology, fauna, depositional environments, biostratigraphy, and paleoclimate of the Yorktown Formation west of the bay have been described by various workers (Mansfield, 1928, 1943; Johnson, 1969, 1972, 1976; Hazel, 1971a,b; Blackwelder and Ward, 1976; Ward and Blackwelder, 1980).
Sinnott and Tibbitts (1968) have reported on the gross lithology and water-bearing characteristics of the Yorktown beds in the Virginia part of the Delmarva Peninsula. However, their data, obtained from widely scattered water wells, did not permit detailed study of depositional environments and facies relationships within the Yorktown Formation.

\section{LITHOSTRATIGRAPHY}

Sufficient borehole data to permit preliminary interpretation of the lithostratigraphy and biostratigraphy of the Yorktown Formation in the southern Delmarva Peninsula are available only in the northern part of the study area. Here a series of boreholes, extending from Crisfield, Md., southeastward across the Delmarva Peninsula to Chincoteague and Assateague Islands, Va., penetrated thin surficial deposits of Quaternary age and as much as $80 \mathrm{ft}(24 \mathrm{~m})$ of the underlying upper Tertiary section. The borehole data are the basis for a generalized geologic cross section (fig. $4 ; A-A^{\prime}$, pl. 2) showing the flat-lying to very gently inclined Quaternary units and their strongly truncating relationships to the more steeply dipping upper Tertiary strata. That successively younger Yorktown beds are encountered from northwest to southeast along the line of section indicates that the regional dip is to the southeast. However, as the base of the Yorktown was reached at only one locality, the amount and direction of regional dip have not been accurately calculated.

The borehole data indicate that the Yorktown Formation in southern Somerset County, Md., and northern Accomack County, Va., is divisible into three members, which are, from bottom to top, (1) the lower shelly sand member, consisting of shelly glauconitic quartz sand more than $40 \mathrm{ft}(12 \mathrm{~m})$ thick, (2) the Tunnels Mill Member, consisting of clayey silt, silty clay, and lesser amounts of very poorly sorted fine to coarse pebbly sand as much as $60 \mathrm{ft}(18 \mathrm{~m})$ thick, and (3) the upper shelly sand member, more than $50 \mathrm{ft}(15 \mathrm{~m})$ thick, which commonly contains abundant large bivalves.

\section{LOWER Shelly SAND MEMBER}

Lithology.-The lower shelly sand member is typically developed in the vicinity of Shelltown, Md., near the mouth of the Pocomoke River (pl. 1). The lower $40 \mathrm{ft}$ $(12 \mathrm{~m})$ of the borehole section at locality $\mathrm{S}-5$, about $1.5 \mathrm{mi}(2.4 \mathrm{~km})$ northwest of Shelltown, is designated the principal reference section (fig. 4). Here the unit consists of clayey, silty, and shelly, fine to medium glauconitic quartz sand interbedded with smaller amounts of 
medium to coarse pebbly sand. At this locality and in northern Accomack County, Va., the fine to coarse glauconitic sands of the lower shelly sand member grade upward into silt, clay, and fine silty sand of the Tunnels Mill Member of the Yorktown.

Fauna.-The lower shelly sand beds contain an abundant molluscan and ostracode fauna; barnacles and coral are also present. A partial list of molluscan species in the borehole section near Shelltown (loc. S-5) includes

\section{Astarte n. sp.}

Corbula sp.

Nuculana sp.

Turritella sp.

Ensis sp.

Chesapecten sp.

Dentalium sp.

Venericardia n. sp.

Eucrassatella sp.

Ecphora sp.

Dosinia sp.

Mercenaria sp.

Verticordia sp.

Pitar sp.

Stewartia? sp.

Epitonium sp.

Paleoenvironment.-The molluscan and ostracode assemblages obtained from the lower shelly sand beds suggest a nearshore-shelf depositional environment of near-normal salinity.

\section{TUNNEISS MILL. MEMBER}

Definition and lithology.-The middle part of the Yorktown sequence is herein named the Tunnels Mill Member for the dominantly clayey and silty beds encountered at 6-68 ft $(2-21 \mathrm{~m})$ below sea level in a borehole near the community of Tunnels Mill, Va. (fig. 5 ; pl. 2, loc. H-22). These strata are designated the type section of the Tunnels Mill Member.

The Tunnels Mill Member consists mainly of greenish- to brownish-gray, micaceous clayey silt, silty clay, and clayey and silty, fine to very fine quartz sand (fig. 5). At several localities, the upper part of the section includes beds of very clayey and silty, medium to coarse gravelly sand, which are interbedded with the finer sediment. The pebble-sized material is mostly quartz and chert. The sandy and gravelly beds are

Figure 5.-Stratigraphic section near Tunnels Mill, Va., including the lower shelly sand member and Tunnels Mill Member of the Yorktown Formation and the overlying Kent Island Formation (see pl. 2, borehole loc. $\mathrm{H}-22$ ). The borehole site is at the junction of county roads 693 and 706 , about $0.6 \mathrm{mi}(1 \mathrm{~km})$ southwest of Tunnels Mill. The Tunnels Mill beds at this locality constitute the type section of the member.
ALTITUDE,

DEPTH, IN FEET

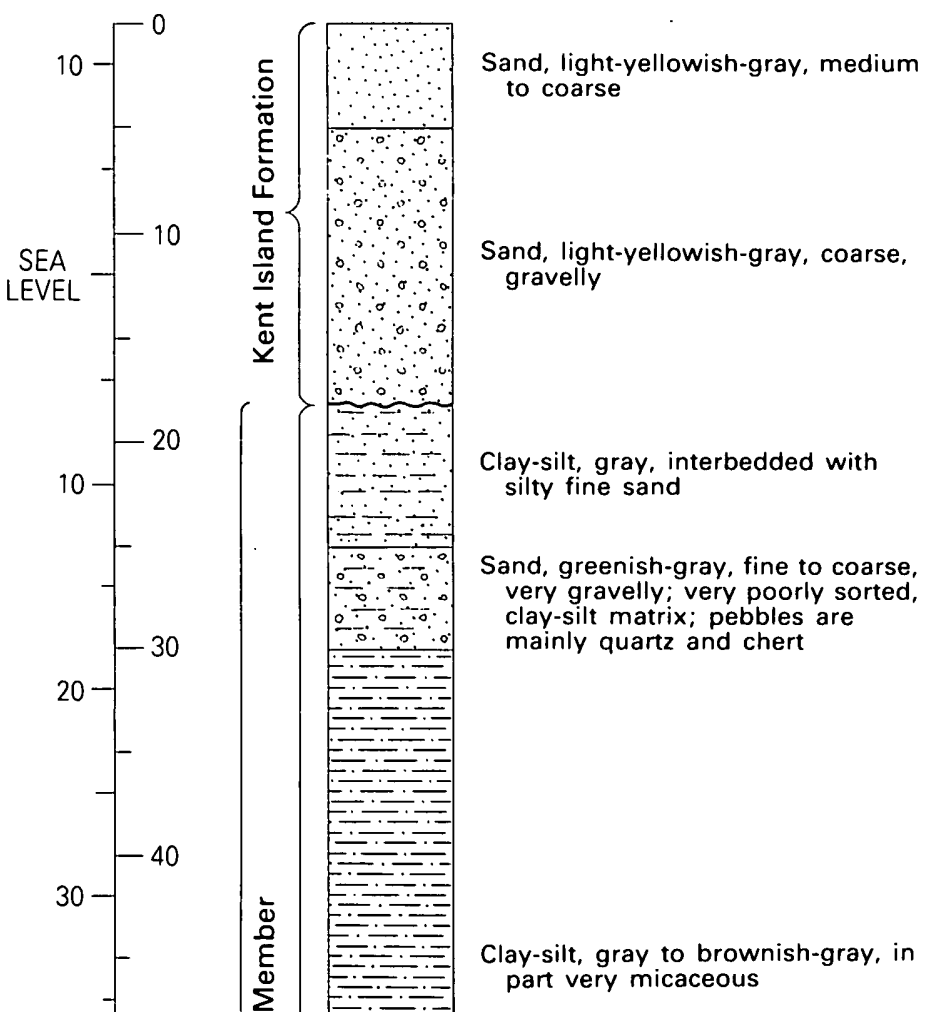

part very micaceous
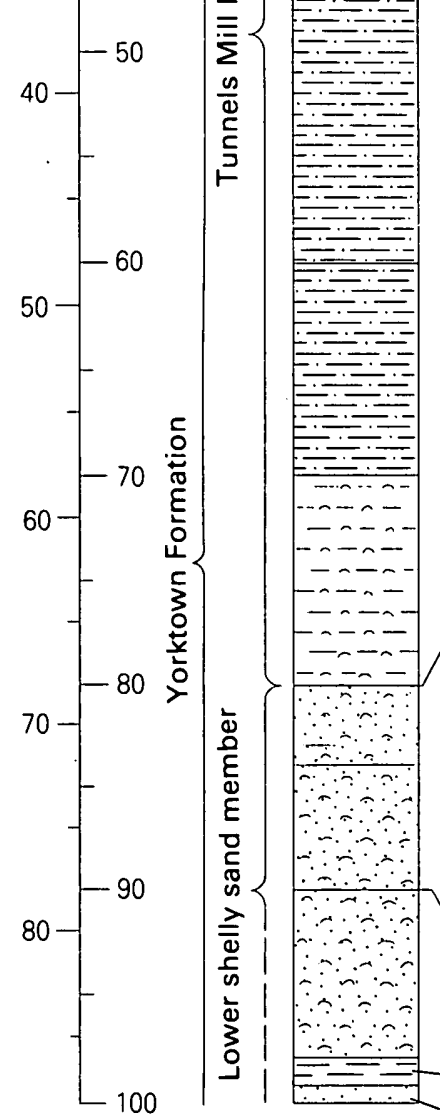

Total depth Sand, greenish-gray, clayey, non$100 \mathrm{ft}$
Clay-silt, greenish-gray

Clay-silt, greenish-gray, scattered fine shells

Sand, greenish-gray, very fine, clayey and silty, scattered fine shell fragments; ostracodes include Echinocythereis planibasalis

Sand greenish-gray, fine to medium, clayey and silty, fragments; ostracodes include Pterygocythereis inexpectata and Actinocythereis marylandica very abundant coarse shell

Clay, hard

fossiliferous glauconitic, abundant fine shell

Sand, greenish-gray, fine to coarse, clayey and silty, glauconitic 
characteristically very poorly sorted. The clays and silts commonly contain pale grayish yellow siderite concretions as much as 3 in $(7 \mathrm{~cm})$ in diameter and sparse fragments of woody material to a maximum of about $1 / 8$ in $(0.3 \mathrm{~cm})$. Calcareous shell material is preserved only in the basal $8-10 \mathrm{ft}(2.5-3 \mathrm{~m})$ of the unit. However, abundant molds and casts of marine mollusks (Ensis sp.?, Pitar sp.?), which were observed in large blocks of sandy clay-silt in spoil adjacent to a borrow pit at the Shelltown, Md., locality (S-5), indicate that the Tunnels Mill originally contained a molluscan fauna.

Stratigraphic relationships. - Where the base of the Tunnels Mill Member has been penetrated by our boreholes (S-5, S-10, H-22, H-23, CW-11), the unit gradationally overlies the fine to coarse, shelly sand of the lower shelly sand member of the Yorktown Formation. Similarly, the Tunnels Mill grades upward into fine to coarse, shelly sand of the upper part of the Yorktown (see fig. 6). Some lateral gradation or intertonguing of the Tunnels Mill with both the lower shelly sand member and the upper shelly sand member of the Yorktown is suggested by data from boreholes offset to the southwest and northeast of the line of cross section (especially S-10, CW-14, CW-11).

Paleoenvironment.-The sharply reduced species diversity of the molluscan and ostracode assemblages in the Tunnels Mill beds and in the basal part of the overlying upper shelly sand member, relative to the diverse assemblages in the lower shelly sand member, suggests a more restricted depositional environment, which may have been separated from the open shelf by a barrier (Blackwelder, Ward, and Hazel, written commun., 1974). The foraminiferal assemblage in the upper part of the Tunnels Mill (loc. H-20), which is dominated by Elphidium clavatum Cushman, also indicates a marginal-marine or brackish-water environment and thus supports the interpretation based on the mollusk and ostracode data (T. Gibson, written commun., 1974). According to Gibson, the corrosion and pyritization of the foraminifer tests suggest diagenetic alteration in a reducing environment rich in organic matter.

Distribution. -The Tunnels Mill subcrop is a 10-miwide (16-km-wide) belt extending northeastward across the Saxis and the western and central parts of the Hallwood 7.5-min quadrangles. The subcrop projects farther northeastward into southeastern Somerset and northwestern Worcester Counties, Md., where the Tunnels Mill and equivalent beds have been included in the "Yorktown and Cohansey Formations (?)" (Rasmussen and Slaughter, 1955; Owens and Denny, 1978). The Tunnels Mill beds have been traced from the type area southwestward into central Accomack County where the section becomes sandier (borehole loc. P-3 near Parksley).
Correlation.-The Tunnels Mill Member is equivalent, at least in part, to the upper confining bed of the "Yorktown and Cohansey Formations(?)" of Rasmussen and Slaughter (1955). The unit may possibly be equivalent in part to the Morgarts Beach Member of the Yorktown, which crops out in the Virginia Coastal Plain west of Chesapeake Bay. The Tunnels Mill beds are much thicker than the Morgarts Beach Member, however, and the clay-silts and fine sands of the Tunnels Mill are interbedded with much coarser sandy and gravelly materials.

UpPer Shelly SAND Member

Definition and lithology.-The upper shelly sand member of the Yorktown is typically developed in the eastern part of the Hallwood quadrangle (pl. 2, locs. $\mathrm{H}-20, \mathrm{H}-21$; fig 6) and in adjacent parts of the Chincoteague West quadrangle (locs. CW-4, CW-14). The unit, which is as much as $45 \mathrm{ft}(14 \mathrm{~m})$ in thickness, consists mostly of fine to coarse glauconitic quartz sand in a clay-silt matrix and commonly contains abundant large bivalves. The coarser sand contains fairly abundant fine to very fine pebbles of quartz and chert. The clay fraction is dominantly illite and montmorillonite but includes some kaolinite and chlorite.

Locally, the shelly sands grade upward into a sandy clay and silt unit, as much as $20 \mathrm{ft}(6 \mathrm{~m})$ in thickness, which is lithically similar to the Tunnels Mill Member. Like the Tunnels Mill, these silts and clays contain scattered small fragments of wood and are commonly interbedded with clayey and silty fine sand.

Stratigraphic relations and distribution.-The upper shelly sand member conformably overlies clays and silts of the Tunnels Mill Member of the Yorktown (loc. $\mathrm{H}-20$ ); the unit may also intertongue with the Tunnels Mill (see above). Beds of the upper shelly sand member can be traced for at least $2 \mathrm{mi}(3 \mathrm{~km})$ to the eastnortheast of borehole H-20. Farther to the northeast, the shelly sand unit pinches out, and, in the northern Chincoteague West quadrangle, it is replaced by sideritic clay-silts of the Tunnels Mill type. Thus, the upper shelly sand may constitute one or more lenticular sand bodies within the upper part of the Tunnels Mill section.

Shelly medium sand that forms the uppermost part of the Yorktown section in the Chincoteague, Va., area (loc. CE-3) is lithically similar to the shell beds near Wattsville but is presumably higher in the section.

Fauna and paleoenvironment.-The molluscan assemblage in the basal $10 \mathrm{ft}(3 \mathrm{~m})$ of the upper shelly sand member loc. H-20, 90- to 100-ft (27- to 30-m) interval] is characterized by low species diversity and poor shell preservation. Nuculana sp., Yoldia sp., and Par- 
vilucina sp. are the dominant forms and, together with a few Ensis sp., Pandora? sp., and Chesapecten sp., indicate a restricted depositional environment for the lower part of the upper shelly sand member. Elphidium clavatum Cushman constitutes about 95 percent of the foraminiferal assemblage, just as it does in the underlying Tunnels Mill Member. As in the Tunnels Mill Member, the foraminifer tests are corroded and full of pyrite, probably as a result of a reducing environment rich in organic matter.

Diversity of species increases upward through the middle part of the upper shelly sand member loc. H-20, 75- to $90-\mathrm{ft}$ (23- to $27-\mathrm{m})$ interval] and moderately large species such as Corbula inaequalis Say, Periploma sp., Pitar sp., Glycymeris sp., Mercenaria sp., and Astarte undulata var. begin to appear. Again, the foraminiferal assemblage is dominated by Elphidium clavatum Cushman. Pyritization and corrosion of tests become less evident upward through this part of the unit; at depths of $75-80 \mathrm{ft}(23-24 \mathrm{~m})$ the major change is recrystallization.

The upper, coarser part of the upper shelly sand member $[\mathrm{H}-20,65-$ to $75-\mathrm{ft}(20-$ to $23-\mathrm{m})$ interval] contains a diverse molluscan assemblage characteristic of shelf or large, open-embayment environments. Species found only in the upper part, not in the lower and middle parts, of the upper shelly sand include Pleuromeris sp., Crassinella lunulata (Conrad), Cyclocardia granulata (Say), Dosinia sp., Polinices sp., Carditamera arata Conrad, Anadara lineosa? (Say), and Pecten eboreus? Conrad.

\section{DEPOSITIONAL, ENVIRONMENTS AND PALEOGEOGRAPHY OF THE YORKTOWN FORMATION}

The glauconitic quartz sands and fairly diverse molluscan and ostracode faunas that form the lower shelly sand member of the Yorktown represent a typical transgressive marine sequence deposited in shallow nearshore-shelf waters. The coarsening-upward sequence of beds of the overlying Tunnels Mill Member and its restricted fauna denote a marked change in depositional environment probably associated with the seaward progradation of a delta system. The sideritic clay-silts and fine sands of the lower Tunnels Mill are interpreted to represent prodelta and delta-front (=distal-bar) deposits at the outer margin of the delta.

Figure 6.-Borehole section about $1.5 \mathrm{mi}(2.4 \mathrm{~km})$ northwest of Wattsville, Va, showing the Tunnels Mill Member and upper shelly sand member of the Yorktown Formation and facies of the overlying Accomack Member of the Omar Formation (pl. 2, loc. H-20). The Accomack beds at this locality have been designated the type section of the member (see following discussion of the Accomack Member).
ALTITUDE

DEPTH, IN FEET

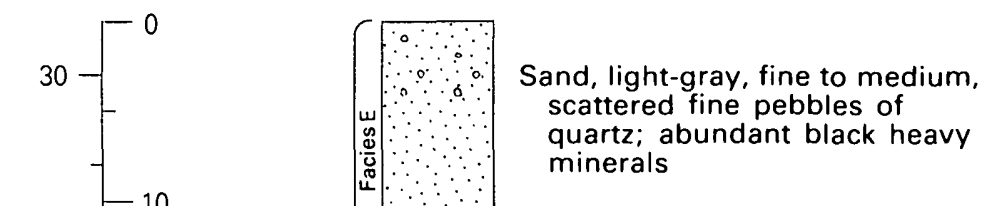

Sand, yellowish-orange (oxidized), medium to coarse

Sand, medium-to dark-gray, fine, clayey and silty, micaceous; sparse mollusks, abundant ostracodes, and very abundant fragments of the encrusting bryozoan Schizoporella floridana

Sand, gray, medium to coarse, clayey and silty; abundant mollusks and ostracodes

LEVE

LEL
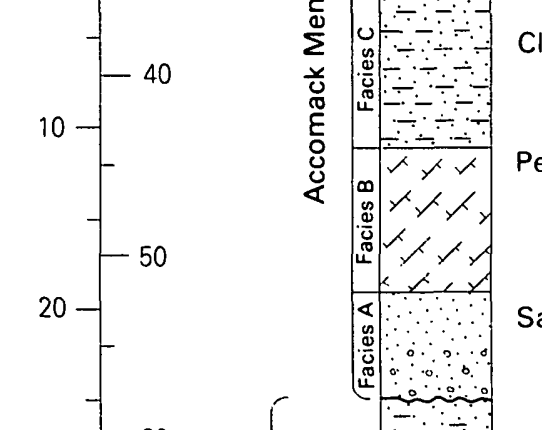

sandy

Peat, dark-reddish-brown, abundant large wood fragments (roots and stumps?); grades upward into fine brownishgray sand

Sand, pale greenish-gray, coarse, pebbly, loose; grades upward into better sorted, fine to medium sand

Sand, greenish-gray, clayey and silty, compact, abundant glauconite, nonfossiliferous; pebble bed at base

Sand, greenish-gray, fine to coarse, clayey and silty, scattered fine pebbles; abundant ostracodes and mollusks

Sand, greenish-gray, very fine to fine, grades upward to fine to medium, clayey and silty, scattered fine pebbles: abundant mollusks and ostracodes but assemblages are less diverse than those of above unit

Sand, greenish-gray, very fine. silty and clayey; grades upward to sandy silt; sparse assemblages of mollusks, ostracodes, and foraminifers indicate restricted depositional environment

Clay-silt, greenish- to brownishgray, micaceous, very compact; abundant light-yellowish-gray nodules of siderite
Total depth $=$ $115 \mathrm{ft}$ 
The poorly sorted muddy and gravelly sands of the upper Tunnels Mill are interpreted to have been deposited in a complex of distributary-mouth bars, channels, and crevasse splays, which built eastward over the prodelta and delta-front muds and muddy sands of the lower Tunnels Mill. The upper shelly sand member is thought to have formed as one or more offshore bars that fringed the delta system.

\section{RELATIONSHIP TO HYDROLOGIC UNITS, AGE, AND CORRELATION}

The abundant well data available in southernmost Maryland enabled Rasmussen and Slaughter (1955, p. 93-103) to divide the upper Miocene [and Pliocene] marine sequences of that area into four hydrologic units named, from bottom to top, (1) the Manokin aquifer, (2) the lower aquiclude, (3) the Pocomoke aquifer, and (4) the upper aquiclude (see this report, fig. 3). As described by these workers, the Manokin and Pocomoke aquifers consist of fine to medium, gray sand interbedded with lesser amounts of coarse sand, fine gravel, and shells (Rasmussen and Slaughter, 1955, table 14). The lower and upper aquicludes were described as gray, blue, and green clayey silt interbedded with "layers" of very fine to medium sand. Rasmussen and Slaughter $(1955$, p. 93) grouped the aquifers and aquicludes (=confining beds) in an informal stratigraphic unit designated the "Yorktown and Cohansey Formations (?)," undifferentiated. On the basis mainly of well-log correlations, Rasmussen and Slaughter considered the "Yorktown and Cohansey Formations (?)" to be correlative to the Yorktown Formation of Virginia and the Cohansey Sand of New Jersey. At that time, both the Yorktown and the Cohansey were thought to be of late Miocene age (Mansfield, 1943). More recently, however, studies of planktonic foraminifers from the Yorktown beds in the Hampton, Va., area west of the Chesapeake Bay suggest that the Yorktown is early to early middle Pliocene rather than late Miocene in age (Akers, 1972, p. 30-34; Ward and Blackwelder, 1980).

The age of the "Yorktown and Cohansey Formations (?)" of Rasmussen and Slaughter and the exact correlation of these strata to mappable lithic units that crop out in the Coastal Plain of Maryland and Virginia west of the Chesapeake Bay have not been fully investigated and are still the subject of some uncertainty. On the basis of fossils from a borehole on the north side of the Manokin River near Venton, Md., Owens and Denny showed that beds of the Manokin aquifer are equivalent, at least in part, to the St. Marys Formation in its type area (St. Marys County) in southern Maryland (see Owens and Denny, 1979b, p. A9, fig. 8). This correlation indicates that the Manokin beds are of late middle to early late (?) Miocene age and, thus, are distinctly older than the.Eastover and Yorktown Formations as presently defined (Ward and Blackwelder, 1980). The lower part of the overlying Pocomoke aquifer includes beds of late Miocene age that appear to correlate with the Eastover Formation (see Owens and Denny, 1979b, p. A10, and the section in this report describing the age and correlation of the Eastover Formation). I consider the middle and upper parts of the Pocomoke aquifer near Shelltown and Pocomoke City, Md., and in areas farther downdip in Virginia and Maryland (Cushing and others, 1973, pl. 10) to be part of the Pliocene Yorktown Formation. This conclusion is based on the abundantly fossiliferous Yorktown strata encountered at depths of -39 to $-70 \mathrm{ft}(-12$ to $-21 \mathrm{~m})$ in borehole S -5 near Shelltown, Md. (fig. 4) and at -70 to $-105 \mathrm{ft}(-21$ to $-32 \mathrm{~m})$ in borehole $\mathrm{CW}-11$, which is about $6 \mathrm{mi}(10 \mathrm{~km})$ southeast of Pocomoke City (see pl. 2). In summary, the "Yorktown and Cohansey Formations (?)" of Rasmussen and Slaughter and the constituent Manokin and Pocomoke aquifers appear to include strata ranging in age from middle Miocene to early or middle Pliocene and to correlate, at least in part, with the St. Marys, Eastover, and Yorktown Formations as used in this report.

\section{QUATERNARY DEPOSITS}

Their lithology, geomorphic expression, environments of deposition, and relative ages suggest that the Quaternary deposits of the southern Delmarva area may be subdivided into three categories: (1) marginal-marine and estuarine deposits related to high stands of the sea during one or more late Pleistocene interglacial stages, (2) fluvial, paludal, and eolian deposits related in part to the fall and subsequent rise in sea level in latest Pleistocene (Wisconsin) and Holocene time, and (3) coastal barrier and lagoonal deposits related to the ongoing Holocene transgression. The interglacial deposits of marginal-marine and estuarine origin form most of the mainland part of the southern Delmarva Peninsula and are the focus of this study. The lithology, depositional environments, paleontology, and lithostratigraphy of these deposits are discussed in detail in the following sections of this report. Deposits of relatively small areal extent (fluvial and eolian deposits; category 2, above), or of large extent but small volume (paludal deposits), are discussed only briefly. The Holocene barrier and lagoonal deposits along the Atlantic side of the peninsula (category 3) have been studied by other investigators, and the reader is referred to their work for detailed descriptions of the Holocene flora, fauna, and sedimentary materials (see Harrison, 1972; Newman and Rusnak, 1965; Newman and Munsart, 1968; Kraft, 1968, 1971). 


\section{DEPOSITS OF UPLAND AREA}

\section{OMAR FORMATION}

Sandy, silty, and gravelly deposits of Pleistocene age that underlie the central upland of the southern Delmarva Peninsula in Accomack County, Va., and that unconformably overlie the Yorktown Formation are the oldest sedimentary sequence cropping out within the study area (see pl. 2; Mixon and others, 1982). These strata form a lithostratigraphic unit, ranging from about 20 to $90 \mathrm{ft}(6-27 \mathrm{~m})$ in thickness, that is equivalent to the Omar Formation as mapped in adjacent areas of southern Maryland (Owens and Denny, 1978; this report, fig. 7).

\section{DEFINITION}

As originally described by Jordan (1962) and Jordan and others (1967), the Omar Formation consists of "interbedded, gray to dark gray, quartz sands and silts" that compose the surficial deposits of much of Sussex County, Del. The type section of the formation is test boring Qh 44-1 near the community of Omar, about $2 \mathrm{mi}(3 \mathrm{~km})$ east of Frankford, Del. (Jordan, 1962, p. 41). In its type area in Sussex County, the Omar is as much as $54 \mathrm{ft}(16 \mathrm{~m})$ in thickness and is found at altitudes ranging from about $60 \mathrm{ft}(18 \mathrm{~m})$ above sea level to $50 \mathrm{ft}$ $(15 \mathrm{~m})$ below sea level. The Omar beds in Delaware are considered to have been deposited mainly in lagoonal and estuarine environments on the basis of faunal assemblages characterized by Crassostrea virginica Gmelin, Mercenaria mercenaria Linne, Noetia ponder osa (Say), and other molluscan species tolerant of brackish-water conditions (Jordan and others, 1967; Jordan, 1974).

The Omar Formation in Delaware and Maryland as defined by Jordan includes most of the Pleistocene deposits in a wide, north-trending outcrop belt bordered on the west by the older, higher Walston Silt-Beaverdam Sand terrane and on the east by the much younger Holocene barrier-lagoon complex (Jordan, 1962; 1974, p. 42). Tentatively excluded from the Omar were Pleistocene beds assigned to the "shoreline complex," a unit consisting of "materials in southern Delaware associated with former beach environments" (Jordan, 1974, p. 43). Jordan considered the "shoreline complex" to be younger than the Omar Formation, at least in part, but suggested that further field work might show a relationship between the "shoreline complex" and the Omar beds. Subsequent to Jordan's work, investigators studying coastal Delaware have included part of the "shoreline complex" in an expanded definition of the Omar Formation (Demarest and others, 1981).

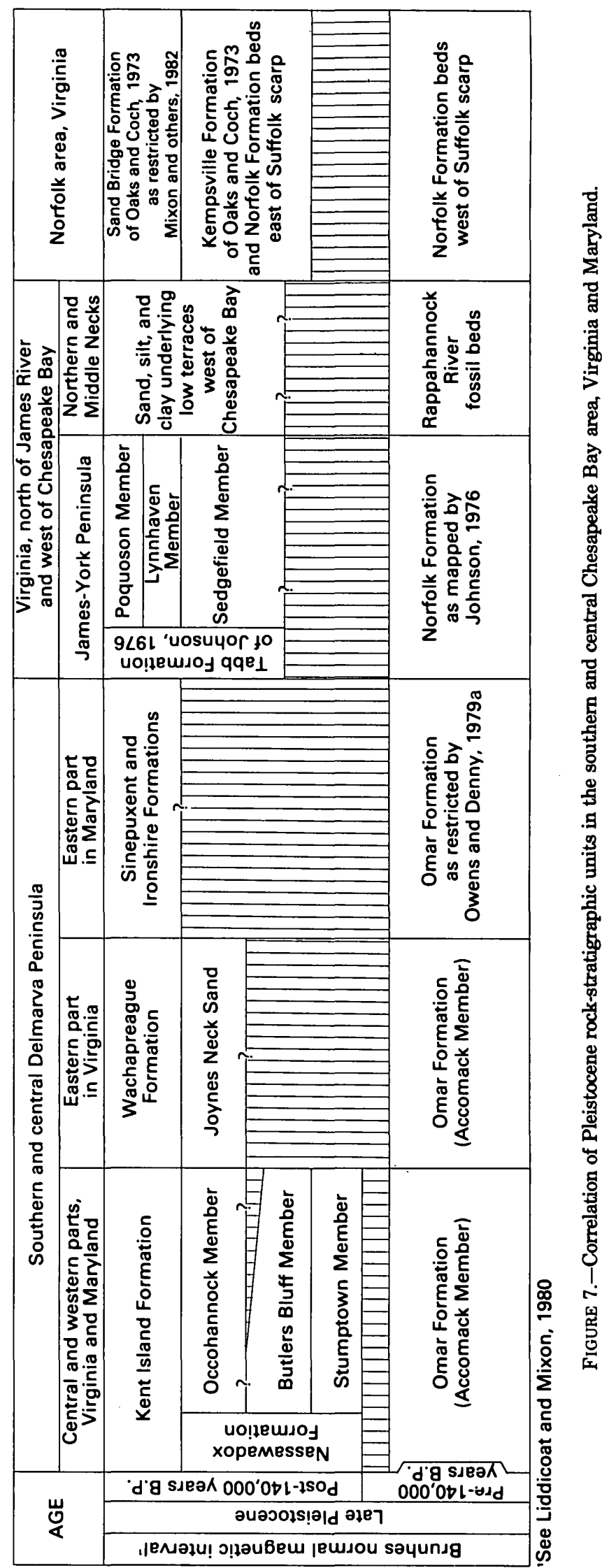


In contrast to the above definition of the Omar, Owens and Denny $(1978,1979 \mathrm{~b})$ have restricted the definition of the formation to include only the beds believed to constitute a single transgressive-regressive sequence deposited during the last(?) interglacial period. Thus, in accordance with this definition, the outcrop of the Omar in Maryland and Delaware is restricted to the central upland plain, averaging $30-40 \mathrm{ft}(9-12 \mathrm{~m})$ in altitude, which borders the east, south, and southwest sides of the older Walston Silt and Beaverdam Sand terrane (Owens and Denny, 1979b, p. A16-A20, fig. 16). Younger Pleistocene beds that truncate and overlie the Omar Formation along its eastern margin of outcrop are assigned by Owens and Denny (1979b, p. A20-A24) to the Ironshire and Sinepuxent Formations.

Beds of Omar age in Virginia differ markedly from the type Omar of Delaware and Maryland in that relatively coarse grained, cleanly washed sand and gravel deposited in highenergy barrier and nearshoreshelf environments greatly predominate over finer sand and mud of lagoonal and estuarine origin. This cleaner, coarser lithofacies of the Omar, which is well developed along and southward of a high on the Tertiary erosion surface extending from Shelltown, Md., to Wallops Station, Va., is herein named the Accomack Member of the Omar Formation. The unit is the "Accomack beds" of Mixon and others (1982).

ACCOMACK MEMBER

The Accomack Member of the Omar Formation is defined as the dominantly transgressive sequence of sand, gravel, silt, clay, and peat that underlies the upland in Accomack County, Va, in the area to the north and west of the Ames Ridge shoreline (pl. 1). The Accomack beds are as much as $80 \mathrm{ft}(24 \mathrm{~m})$ thick in the upland area but are thinner to the east and west of the upland where the unit is truncated and overlapped by younger strata of the Joynes Neck Sand and the Kent Island Formation. The 58-ft-thick (18-m-thick) section of the Accomack penetrated by borehole $\mathrm{H}-20$ in northern Accomack County, Va., is designated the type section of the member (see fig. 6; pl. 2). The type section includes five of the seven sedimentary facies that constitute the Accomack Member. However, the clean, crossbedded gravelly sand of the Accomack (facies E, discussed below) and the planar-bedded fine to medium sand (facies F) are thicker and more easily studied in sand and gravel pits in the upland area in eastern and southern Accomack County. Therefore, the sand pits near Wattsville, Persimmon Point, and Accomac are designated reference sections (for pit locations refer to the Chincoteague West, Bloxom, and Accomac 7.5-min quadrangles).
Description of Sedimentary Facies

Seven principal interfingering and overlapping sedimentary facies, representing closely related marginal-marine depositional environments, have been identified in boreholes penetrating the Accomack Member of the Omar Formation in Accomack County, Va. The crossbedded gravelly sand facies may be further divided into subfacies on the basis of sedimentary structures and other lithic characteristics observable in outcrop sections. The sedimentary facies form a vertical stratigraphic sequence that generally consists of the following units, from bottom to top:

Facies $A$.-Basal gravelly sand. The basal lithic unit of the Omar Formation is clean, loose, medium to coarse, gravelly sand and sandy gravel; it contrasts markedly with the directly underlying, much more compact glauconitic sands and clay-silts of the Yorktown Formation (fig. 8). The unit ranges in thickness from less than $1 \mathrm{ft}(0.3 \mathrm{~m})$ to as much as $30 \mathrm{ft}(9 \mathrm{~m})$ where it fills low areas on the irregular erosion surface at the top of the upper Tertiary stratigraphic section.

Pebble gravel clasts consist mainly of vein quartz and dark gray to black chert and include minor amounts of sandstone, quartzite, schist, and gneiss. Cobble- and boulder-sized clasts, mostly sandstone and quartzite, are fairly common in spoil from borrow pits and irrigation ponds excavated where the basal part of the Omar Formation is near the surface, as in the Saxis, Parksley, and western Hallwood quadrangles.

Facies B.-Peat and brownish-gray mud and sand. Peat and (or) organic-matter-rich mud and fine sand of facies B commonly overlie the coarse gravelly sand of facies A (see fig. 8). Typically, peat averaging $1-3 \mathrm{ft}$ $(0.3-1 \mathrm{~m})$ in thickness is interbedded with, or overlain by, 4-5 ft (1.2-1.5 m) of brownish-gray sand and mud containing abundant fine to coarse fragments of wood. Peat attains a maximum observed thickness of $7 \mathrm{ft}$ $(2.1 \mathrm{~m})$ in a narrow, north-trending paleovalley cut into the upper Yorktown beds to the northwest of Wattsville (borehole loc. H-20). Peat composition varies from coarse to very coarse woody peat (roots and stumps) to finer peat composed mainly of fragments of salt-marsh grasses Spartina alterniflora and Spartina patens.

The contact between sediments of facies A and B, observed only in borehole sections, is fairly abrupt but conformable. Locally, over highs on the Yorktown erosion surface, the basal gravelly sand facies is missing and the peat and brown sand and mud facies directly overlies the Yorktown beds (for example, at loc. CW-14). Sediments of facies B are generally thin or absent where the gravelly sands of facies A are thickest, that is, near major cross-peninsula paleodrainages (see fig. 9). 
ALTITUDE,

DEPTH, IN FEET
THICKNESS
FEFT (METERS)

\begin{tabular}{|l|l|l|ll}
\hline & $\overline{\bar{i}}$ & $\begin{array}{l}\times{ }^{\times} \times{ }^{\times} \times \\
x^{\times} \times\end{array}$ & $2(6)$ & Sand, gray, abundant shell fragments \\
\hline$\overline{\bar{\delta}}$ & $-\cdots$ & $3(1)$ & Clay loam, gray, mottled yellow-orange
\end{tabular}

Sand, gray, clayey and silty; pebbles as much as $1 / 2$ inch $(1.5$ $\mathrm{cm}$ ) in diameter

Sand, greenish-gray, fine, clayey and silty

Sand, medium-gray, fine to medium, clayey and silty; abundant mollusks dominated by Mercenaria; Noetia sp. Ensis sp., Corbula contracta, Cardita tridentata, and Nassarius trivittatus are common; Donax variabilis, Spisula solidissima, Lunatia sp., Nucula proxima, Mitrella lunata, Turbonilla interrupta, Illyanassa obsoletus, Anadara transversa, Crepidula fornicata, Anachis lafresnaya, and Tellina agilis are less common.

Clay-silt, dark-gray; scattered chalky white shell (Crassostrea, Mulinia, Macoma), wood fragments

Sand, gray to brown, clayey and silty

$6(1.8)$

Peat; contains wood fragments as much as 2 inches $(5 \mathrm{~cm})$ in diameter

Sand, fine, brownish-gray

Sand, gravelly; quartz and chert pebbles as much as 1 inch $(2.5 \mathrm{~cm})$ in diameter

Sand, greenish-gray, fine to medium, silty and clayey; scattered fine pebbles

Figure 8.-Borehole section showing the Accomack Member of the Omar Formation and underlying beds at T's Corner, Va. (loc. H-8). From bottom to top, the section includes part of the Tunnels Mill Member of the Yorktown Formation and the basal gravelly sand, peat, gray clay-silt, and bedded muddy sand facies (A-D) of the Accomack, which are interpreted to have been deposited in lagoonal and barrier-inlet environments. 


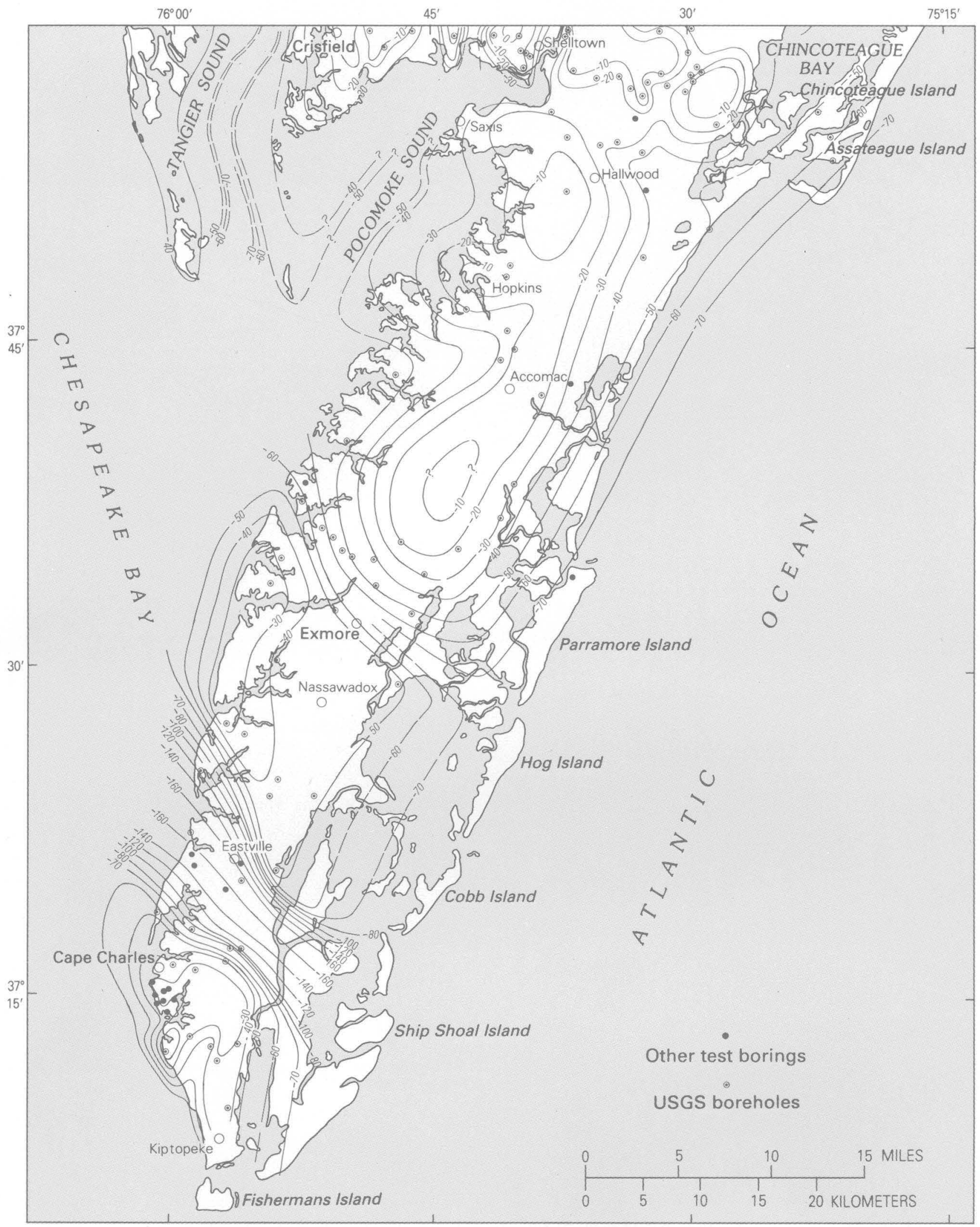

FIGURE 9.-Map of the erosion surface on the top of the Tertiary beds in the southern Delmarva Peninsula, Va. and southernmost Md. Contour interval is $10 \mathrm{ft}(3 \mathrm{~m})$ to depths of $-80 \mathrm{ft}(-24 \mathrm{~m})$ below sea level and $20 \mathrm{ft}(6 \mathrm{~m})$ from depths of -80 to $-160 \mathrm{ft}(-24$ to $-49 \mathrm{~m})$ below sea level. 
Facies C.-Dark-gray clay-silt and nonbedded sand. The brownish-gray peaty mud and sand of facies B grade upward into soft, dark-gray mud of facies C, averaging $3-10 \mathrm{ft}(1-3 \mathrm{~m})$ in thickness, which contains poorly preserved, chalky white shells (Crassostrea virginica, Macoma? sp., Mulinia? sp.). Commonly, the dark-gray mud grades upward, in turn, into gray, muddy, fine to medium sand in which almost all bedding structures have been destroyed by intense burrowing activity. Burrow types include clay-lined, sand-filled burrows resembling Ophiomorpha. Locally, accumulations of the oyster Crassostrea virginica form 1- to 2 -ftthick (0.3- to 0.6-m-thick) shell beds of small lateral extent (fig. 10).

In the western and central parts of the upland, the dark-gray mud and nonbedded sand of facies C commonly underlie conformably, or intertongue with, the bedded, muddy and shelly sand of facies D. In the eastern part of the upland, the muddy deposits of facies $\mathrm{C}$ disconformably underlie the clean, crossbedded gravelly sand of facies $\mathrm{E}$; locally, facies $\mathrm{C}$ sediments intertongue with 2 - to 4 -ft-thick (0.6- to 1.2 -m-thick) units of clean, relatively well sorted, pale-gray to yellowish-gray sand of facies $\mathrm{E}$ (see borehole loc. H-27).

Beds typical of facies $\mathrm{C}$ are well exposed in wavecut cliffs at Red Hill on the west side of Chincoteague Bay and in borrow pits at Assawoman (see Bloxom quadrangle) and north of Wattsville near borehole locality CW-4.

Facies D.-Bedded, fine to coarse, muddy sand. Fine to coarse, gray sand, in part muddy, pebbly, and shelly, commonly overlies the soft muds and muddy, nonbedded sands of facies C. Because of the disturbed nature of the auger samples, bedding has not been observed directly in this subsurface unit; however, the sediment size and the abrupt vertical textural changes

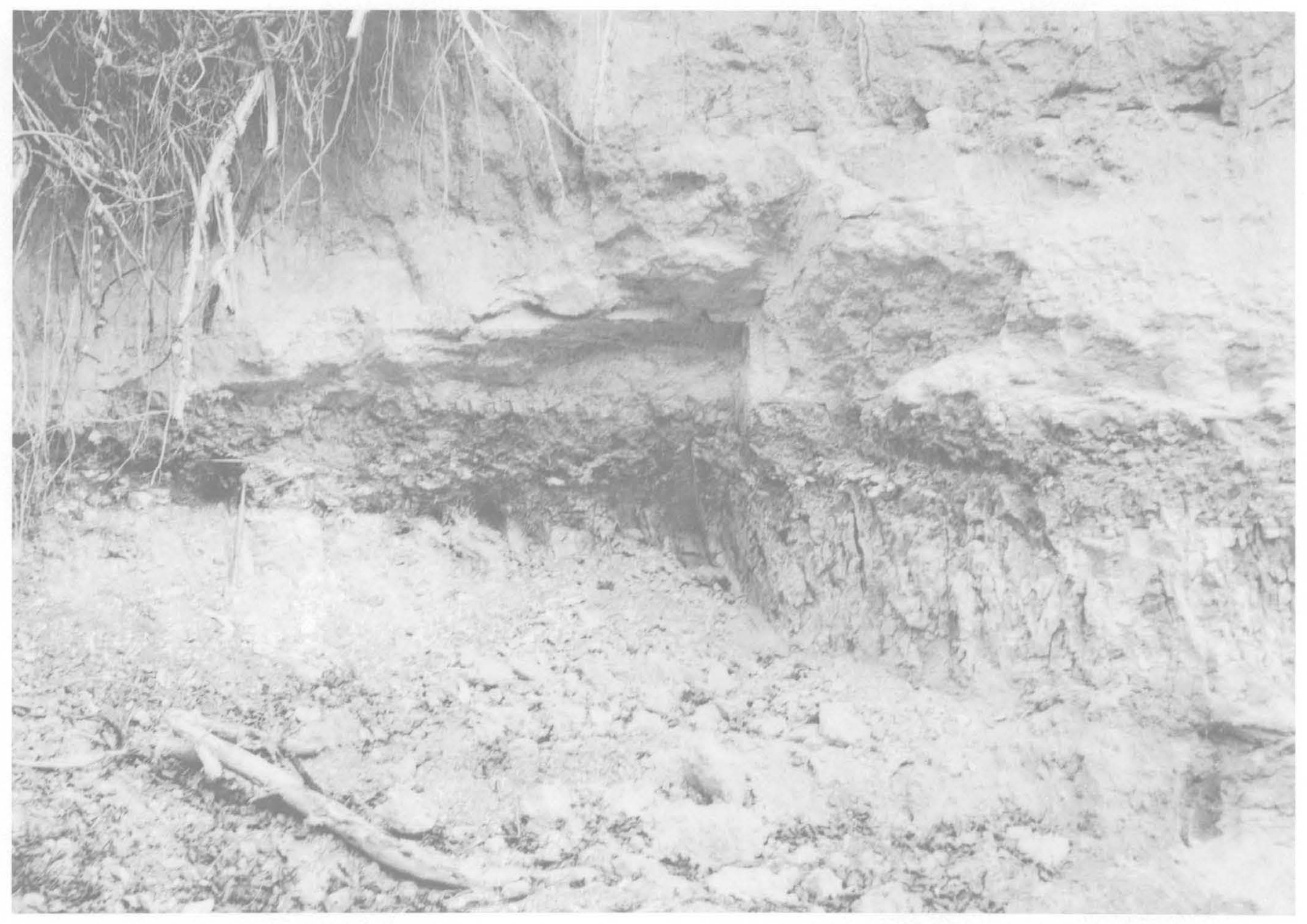

Figure 10.-Section of facies C of the Accomack Member of the Omar Formation in borrow pit at Assawoman, Va. From bottom to top, section includes blocky, gray clay-silt (lower right), a thin discontinuous bed of Crassostrea virginica Gmelin (center), and muddy, poorly sorted sand interpreted to have been deposited in a lagoonal environment. For scale, note small 21-in-long entrenching shovel, left side of photograph. 
in borehole sections strongly suggest that sands of this facies are well bedded (probably crossbedded, at least in part). In northern Accomack County, facies D sands range in thickness from about 5 to $25 \mathrm{ft}(2-8 \mathrm{~m})$ and commonly include one or more fining-upward sequences. A typical sequence (fig. 6) consists of fine to medium or medium to coarse, poorly sorted sand, pebbly at the base, which grades upward into moderately well sorted to well-sorted fine sand. Clay and silt in varying amounts are present as matrix or as thin interbeds of silty clay.

The bedded gray sands of facies $\mathrm{D}$ contain an abundant, well-preserved fossil fauna including mollusks, bryozoans, corals, ostracodes, and foraminifers. The quahog Mercenaria campechiensis generally dominates the molluscan assemblage. Locally, other bivalves, including Noetia sp., Ensis sp., Corbula contracta, and Cardita tridentata, and the scavenger snail Nassarius trivittatus are common to abundant. Species such as Donax variabilis and Spisula solidissima, which are indicative of open-marine environments, are present in small numbers. The encrusting bryozoan Schizoporella floridana, one of the few bryozoa tolerant of brackishwater conditions, is also fairly common in sediments of this facies.

The contact between the bedded, shelly sands of facies $\mathrm{D}$ and the underlying soft muds and fine nonbedded sands of facies $\mathrm{C}$ may be either gradational (see loc. H-20) or abrupt (H-28, H-37). Locally, deposits representing facies $\mathrm{C}$ are missing and coarse pebbly sand of facies D directly and abruptly overlies dark brown clay and peat of facies B (loc. H-26).

Facies E.-Clean, crossbedded, gravelly sand. Fairly clean, loose, pale-gray to light yellowish gray, crossbedded sand that constitutes the surficial deposits over most of the central upland area in Accomack County is here included in facies $E$ (pl. 1). Along the eastern side of the upland, in the Chincoteague West, Hallwood, and Bloxom quadrangles, this facies is typically $25-40 \mathrm{ft}$ $(8-12 \mathrm{~m})$ thick and consists of medium to coarse, poorly sorted, pebbly sand interstratified with lesser amounts of fine-grained, moderately well sorted sand (fig. 11). Locally, minor clay-silt is present as thin foreset laminae in dominantly sandy crossbed units and, more rarely, as infills in ripple troughs (fig. 12). All calcium carbonate has been leached from these deposits, as shown by scattered, dark-brown "ghosts" of bivalves. To the northwest, in the central and western parts of the upland area, the clean crossbedded sand facies becomes thinner and finer grained and overlaps or interfingers with muddy and shelly sands of facies $C$ and $D$. In the vicinity of the Oak Hall scarp (pl. 1), at the northwest- ern edge of the upland in the Hallwood quadrangle, facies $E$ sediments pinch out or are truncated by younger beds of the Kent Island Formation. Facies E deposits are characterized by high-angle trough and tabular crossbedding in sets ranging in thickness from about 8 to 40 in $(20-100 \mathrm{~cm})$. Summary observations of trough crossbedding, which is the dominant type, indicate both northwest (landward) and southeast (seaward) dips; there is also a pronounced component of southwest and northeast dips parallel to the inferred shoreline.

Facies F.-Planar-bedded, fine to medium sand. Moderately well sorted to well-sorted, light yellowish gray sand in units $10 \mathrm{ft}(3 \mathrm{~m})$ or more thick forms a distinctive sedimentary facies exposed at two locations along the eastern side of the central upland. Typically, laminated to very thin bedded sand forms long, continuous, planar beds that are very gently inclined to the southeast, normal to the postulated paleo-shoreline (fig. 13). Some thin sand beds with high concentrations of black heavy minerals (fig. 14) show small vertical burrows and disturbed bedding, which are characteristic of burrowing activity by small crustaceans (amphipods). No body fossils have been observed in this facies.

The planar-bedded, well-sorted sand facies appears to intertongue with coarser, crossbedded sands of facies $\mathrm{E}$.

Facies G.-Muddy and shelly fine sand. Very fine to fine sand, muddy and shelly in part, forms an entirely subsurface lithic unit as much as $25 \mathrm{ft}(8 \mathrm{~m})$ in thickness, which is encountered in boreholes in the eastern and southern parts of Accomack County. Typically, light- to medium-gray muddy sand in units $5-10 \mathrm{ft}$ $(1.5-3 \mathrm{~m})$ thick is interstratified with lesser amounts of clay-silt in beds as much as $3 \mathrm{ft}(1 \mathrm{~m})$ in thickness. The sand fraction, consisting mainly of quartz and feldspar, is moderately well sorted to well sorted. Black heavy minerals, chiefly ilmenite and magnetite, and muscovite are the most abundant and most conspicuous accessory minerals.

In the early 1970 's, shelly sands, which appear to be assignable to facies $G$, were exposed temporarily in a

Figure 11.-Burrowed, crossbedded, medium to coarse pebbly sands inferred to have been deposited in the surf zone environment. Exposures are of facies $E$ of the Accomack Member of the Omar Formation in borrow pit about $0.5 \mathrm{mi}(0.8 \mathrm{~km})$ southeast of Accomac, Va. Top, abundant dark ghosts of fragmented shells in pebbly sand are a result of leaching of all calcareous material. The flat to slightly curving shell fragments are commonly alined with crossbed laminae and are most abundant in middle part of photo. Pencil at bottom for scale. Bottom, erosion surface at base of laterally extensive gravelly sand unit and gradational contact with overlying finer sands is similar to the longshore bar-trough-rip channel sequence described by Hunter and others (1979). Shovel at bottom right for scale. 

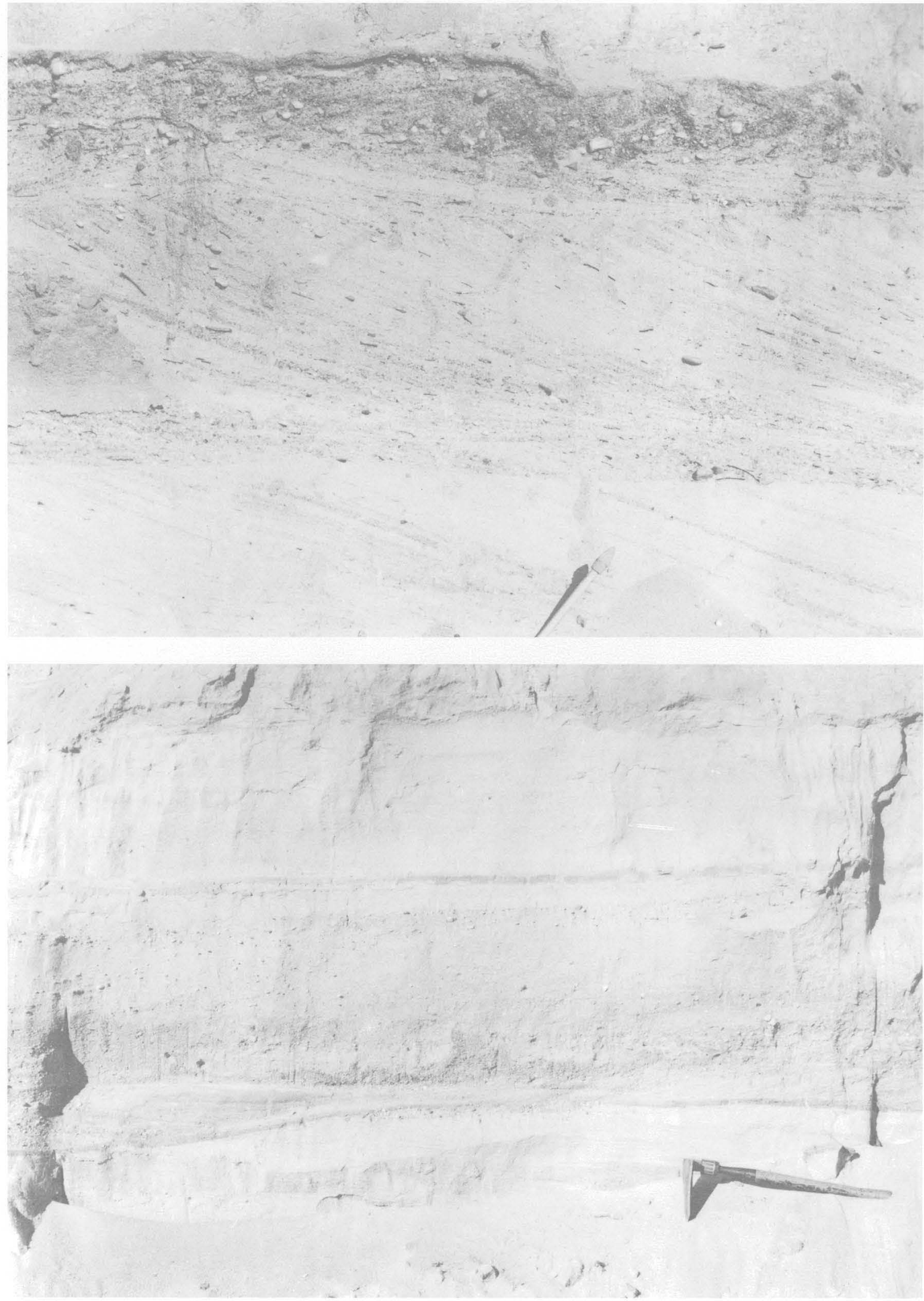


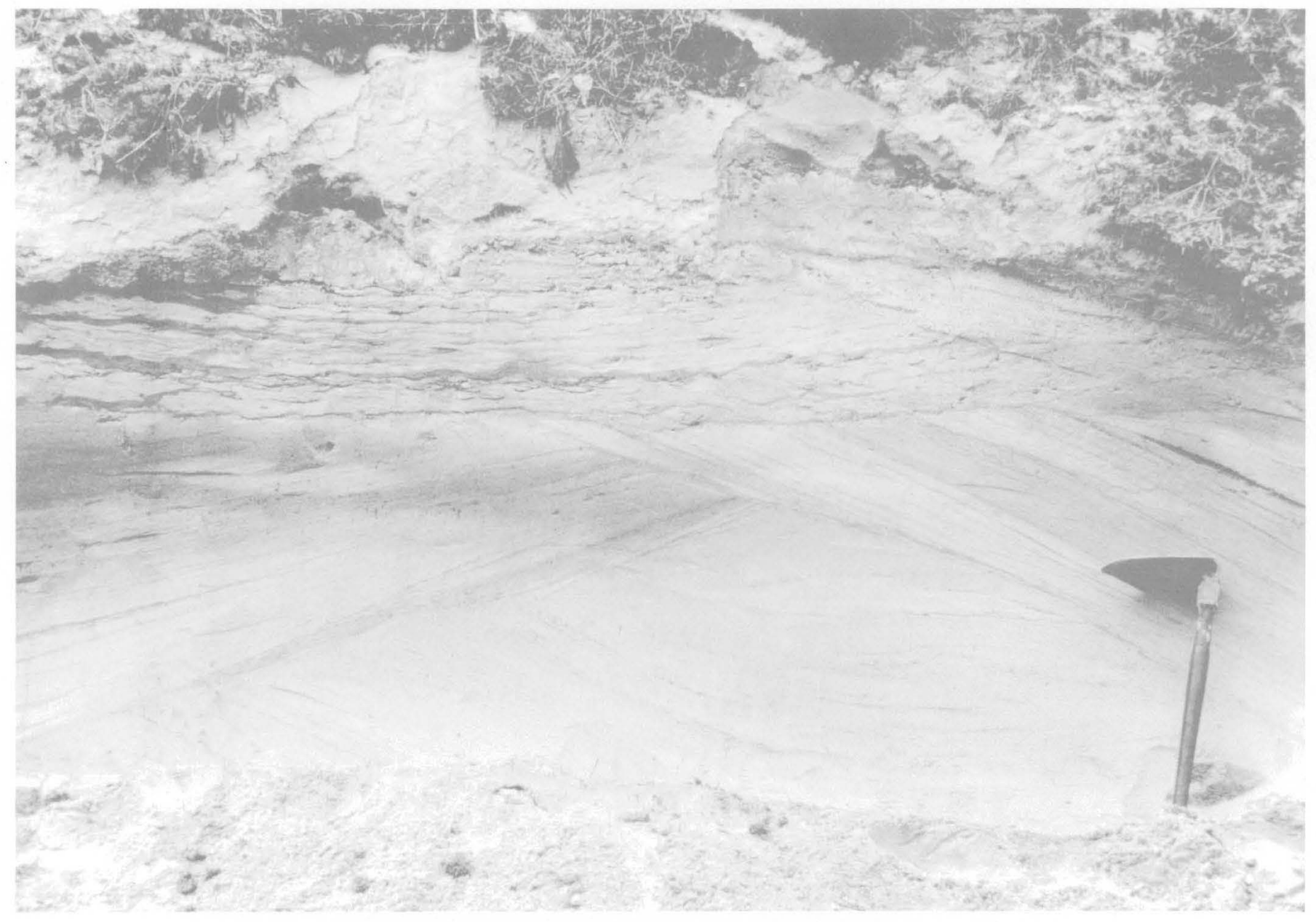

FIGURE 12.-Clean, crossbedded sands of facies E of the Accomack Member of the Omar Formation in roadcut near Horntown, Va. (loc. CW-2). Clay-filled ripple troughs (above) and opposing, large-scale crossbeds (below) suggest deposition in the tidally influenced nearshore of barrier or barrier-inlet environments. Shovel at lower right for scale.

large excavation on the grounds of the Perdue Foods plant about $1 \mathrm{mi}(1.6 \mathrm{~km})$ northeast of Accomac. The molluscan assemblage in the shelly sands at this locality is characterized by the abundance of the surf clam Spisula solidissima (fig. 15); most specimens were juveniles, about $0.5-1$ in $(1-2.5 \mathrm{~cm})$ long, but there were also a few adults (Michael Castagna, Virginia Institute of Marine Sciences, oral commun., 1971). Other common species at the Accomac locality include the razor clam Ensis sp. and the jingle shell Anomia simplex. The assemblage included only two specimens of Mercenaria. Species not reported from the exposure at the Perdue Foods plant, but which are common in borehole samples from nearby localities (A-15, A-16), include Mulinia lateralis, Polinices duplicatus, and the mud snail Nassarius trivittatus. The muddy and shelly fine sands of facies G directly overlie thin basal pebbly sands of facies A and, in turn, are commonly overlain fairly abruptly by coarser, crossbedded sands of facies E. To the west and north, facies $\mathrm{G}$ sands appear to interfinger with sediments of facies $\mathrm{D}$ and $\mathrm{E}$.

Interpretation of Sedimentary Environments

Facies A.-The clean, coarse gravelly sand and sandy gravel of facies A is interpreted to be chiefly a surfwinnowed lag deposit formed by erosion and reworking of older sediments at and near the landward margin of the transgressing sea. Even in areas of thicker gravelly deposits, the general absence of clay-silt matrix and the interbedding of the coarser gravelly material with wellsorted fine sand similar to that in the middle part of the Omar sequence is suggestive of marginal-marine rather than fluvial depositional environments. However, where facies A deposits fill lows in the erosion surface at the top of the Yorktown, they probably include reworked fluvial materials and tidal-channel deposits. 


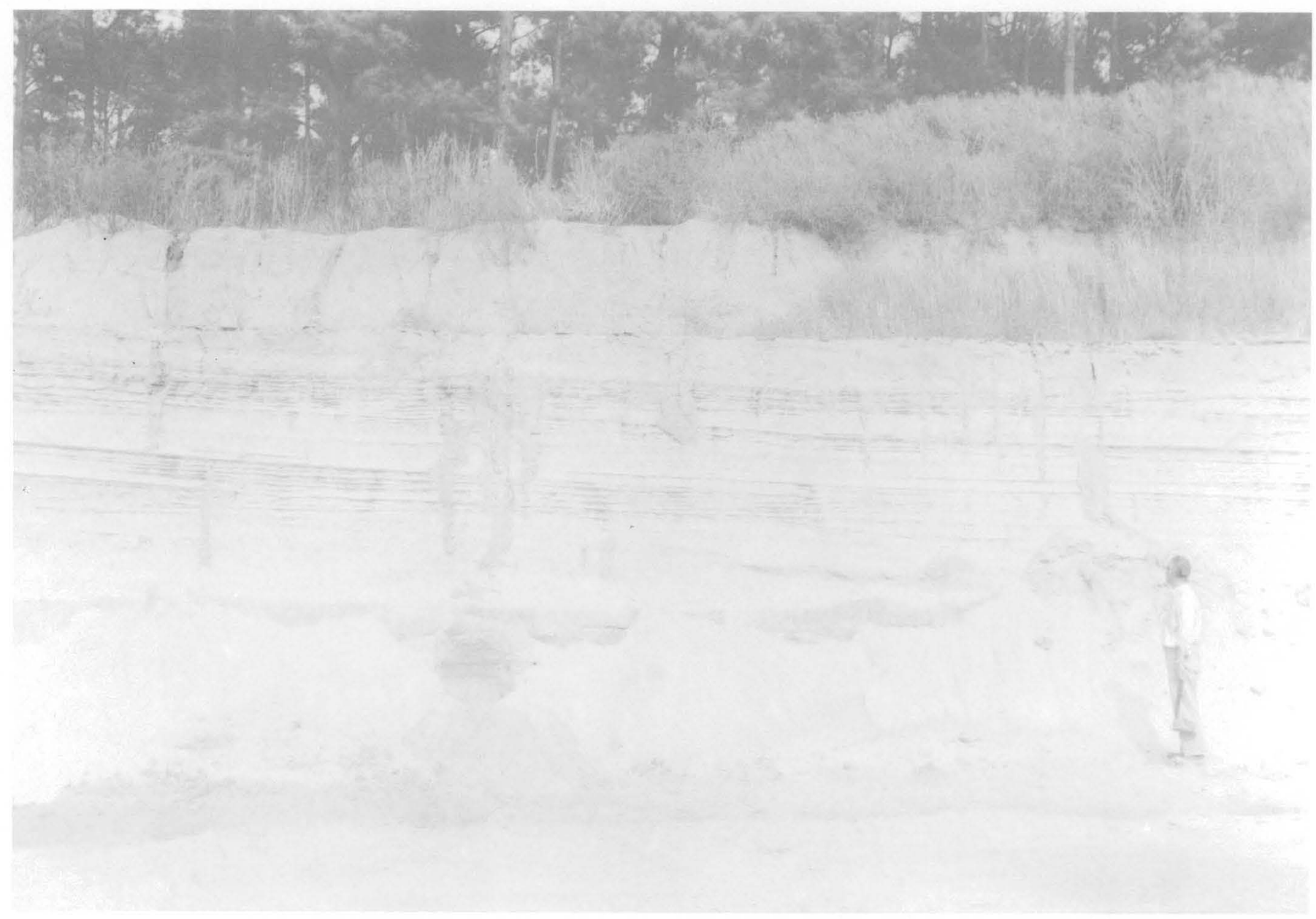

FIGURE 13.-Moderately well sorted, fine to medium sand in continuous planar beds (facies F) very gently inclined in the seaward direction. Exposure is of the Accomack Member of the Omar Formation at the eastern edge of the central upland in the Abbott pit, about 0.75 mi $(1.2 \mathrm{~km})$ southeast of Persimmon Point, Va.

Source beds for the abundant quartz and chert pebbles in the basal gravelly sand are probably the directly underlying Yorktown and Eastover Formations and the extensive sand and gravel sheets of fluvial origin that overlie the Yorktown and older Tertiary beds in the central and northern parts of the Delmarva Peninsula (Owens and Denny, 1979b; Owens and Minard, 1979). The cobble- and boulder-sized clasts of sandstone, quartzite, gneiss, and schist must be reworked from fluvial deposits of post-Yorktown age.

Facies B.-The peat, peaty mud, and fine muddy sand of facies B, in contrast to facies $\mathrm{A}$, represent deposition in low-energy coastal environments protected from the sea by a barrier-island or barrier-spit complex. The coarse woody peat, which appears to include tree stump, root, and limb material, commonly grades upward and laterally into fine peat dominated by Spartina and other salt-marsh plants. Thus, the woody peat is thought to have formed at the landward edge of the salt marsh and in tidal creeks that fed into the lagoon (see marsh-fringe environment of Kraft, 1971, p. 2147). In these areas, the normal coastal forest vegetation is killed by saltwater intrusion, resulting from storm tides or coastal erosion, and is incorporated into peat.

Facies C.-The fine sediment size, poor sorting, and low species diversity of molluscan and microfaunal assemblages that characterize the dark-gray mud and muddy sand of facies $\mathrm{C}$ indicate a quite restricted, lowenergy environment similar to that prevailing during deposition of facies B. The dark sediment color and poorly preserved, chalky shell material indicate reducing conditions. The dark mud and muddy sand lithology, the close association of facies $\mathrm{C}$ with the peaty sediments of facies B, and the common occurrence of the edible oyster Crassostrea virginica Gmelin suggest deposition in the more restricted parts of a coastal lagoon (see also Kraft, 1971; Kraft and John, 1979). 

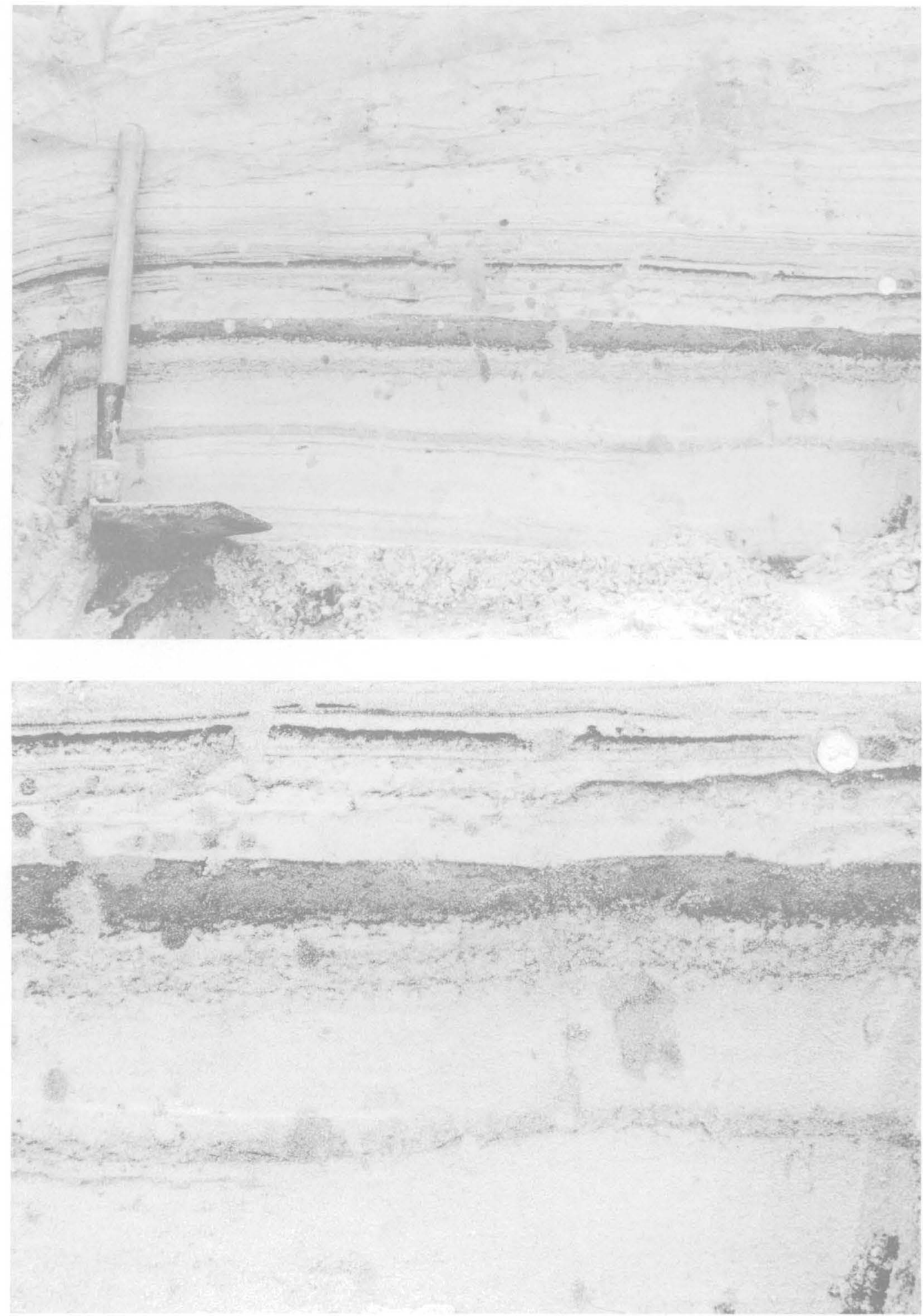

Figure 14.-Dominantly planar-bedded fine sand (facies F) of the Accomack Member of the Omar Formation characterized by abundant black heavy minerals and small vertical and horizontal burrows. Exposure is in the Abbott pit near Persimmon Point, Va. (see fig. 13). Top, swash-zone deposits shown in lower and middle parts of photograph consist of laminae and thin beds of black heavy minerals, mainly ilmenite and magnetite, alternating with pale-gray to white quartz sand. Unit is partly truncated by ripple-bedded sand (upper part of photo); axes of ripple troughs trend roughly parallel to paleoshoreline. Bottom, close-up of lower right part of exposure shows the fuzzy, disturbed bedding believed to indicate intense burrowing by amphipods. 


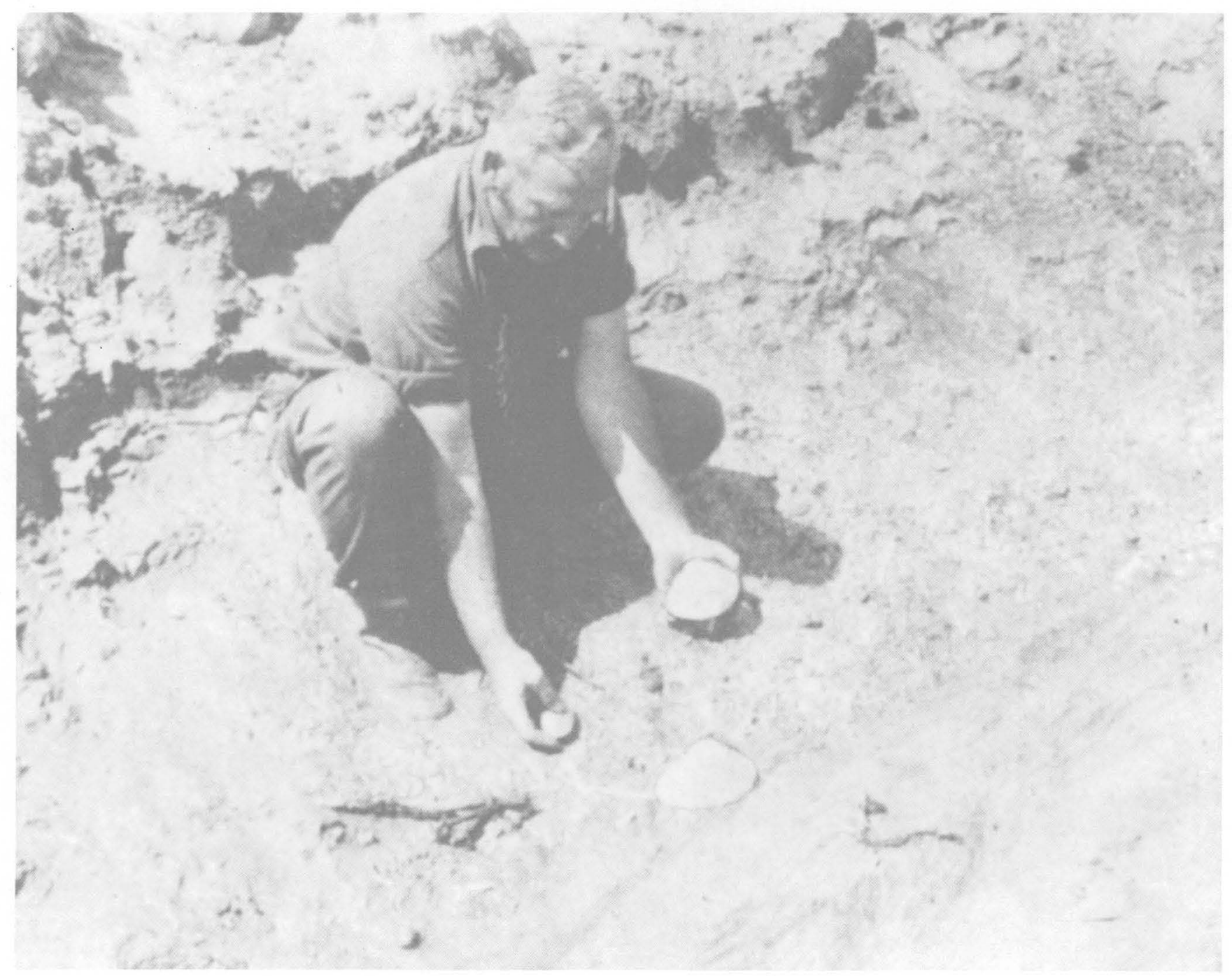

Figure 15. - Large adult forms of the surf clam Spisula solidissima in shelly sands believed to represent facies G of the Accomack Member of the Omar Formation. Exposure is in a 50-ft-deep (15-m-deep) excavation made for waste-disposal lagoon at Perdue Foods plant near Accomac, Va.

Facies D.-The well-preserved fossil fauna of the fine to coarse shelly sand facies indicates deposition in two or more closely related subenvironments of the coastallagoon depositional system. Molluscan assemblages consisting mainly of Mercenaria suggest deposition in shallow bays and coves well protected from the sea by barrier islands or barrier spits. However, the relative coarseness and bedded nature of the deposits, compared to facies $\mathrm{C}$, indicate proximity to active parts of the barrier system (tidal delta and washover fan) and greater exposure to tidal and wind-driven currents. The more diverse molluscan assemblages, dominated by $\mathrm{Mer}$ cenaria but including Noetia, Ensis, Spisula, Donax, and other bivalves, represent mixing of lagoonal and shallow nearshore-shelf faunas such as occur in and near inlets between barrier islands (loc. $\mathrm{H}-8$ ). The ostracode assemblages from the beds containing the mixed molluscan faunas are dominated by species that live in shallow nearshore-shelf waters of normal marine salinity. The shelly sands of facies D appear to have been deposited in open lagoon and barrier-inlet environments that differ considerably in turbulence, turbidity, and bottom conditions within a short horizontal distance. Facies D deposits are inferred to grade laterally into the nonbedded, fine to medium sands of facies $\mathrm{C}$ and to grade into, or interfinger, seaward with the fine shelly sands of facies $\mathrm{G}$.

Facies E.-Textures and structures of the clean, crossbedded, gravelly sand facies, in marked contrast to the previously described lagoonal sediments, indicate 
considerable reworking and winnowing by waves and currents in a high-energy depositional environment. A marginal-marine rather than fluvial or deltaic origin for the crossbedded sands is indicated by (1) landward pinch-out of the sand body, (2) clay-lined burrows of the Ophiomorpha nodosa type, (3) ghosts of marine bivalves, and (4) interfingering and overlapping relationships with the lagoonal and barrier-inlet deposits of facies $\mathbb{C}$ and $D$. Thus, facies $\mathbb{E}$ and closely associated deposits (facies $F$ and $G$ ) represent different subenvironments of barrier island, barrier spit, and very nearshoreshelf depositional systems (Kraft, 1971; Clifton and others, 1971; Kraft and others, 1978; Hunter and others, 1979).

Much of the poorly sorted, medium to coarse, pebbly sand with landward-dipping trough crossbedding is similar to high-angle crossbedded sand and gravel described by Kraft (1971, p. 2145, figs. 16 and 23) as tidal delta deposits. These coarse pebbly sands commonly grade upward into better sorted, finer sands, which appear to be part of the tidal delta-washover fan complex. The local occurrence of thin-bedded sand characterized by mud-filled ripple troughs (flaser bedding) is very suggestive of intermittent current activity in tidally influenced waters (fig. 12). The base of the pebbly crossbedded sand commonly sharply overlies fine, well sorted sublagconal sands that grade downward into muddy and shelly lagconal deposits (facies $\mathrm{C}$ and $\mathrm{D}$ ); this truncating relationship suggests lateral migration of barrier inlets and tidal deltas (see Kraft, 1971, fig. 16).

Along the east side of the central upland, some of the uppermost medium to coarse gravelly sand and sandy gravel is characterized by landward- and seawarddipping high-angle trough crossbedding with pro nounced southwest and northeast dip components parallel to the inferred shoreline and longshore current direction. The coarse sediment size and predominance of seaward- and longshore-dipping crossbeds suggest deposition in and near the surf zone of the nearshore shelf (Clifton and others, 1971; Hunter and others, 1979). Locally, the abundant broken shell material in the pebbly sands, which at present is evident only as dark-brown shell ghosts, supports the interpretation of a very high energy, nearshore depositional environment. Shelly and gravelly sands of this facies are particularly well exposed in borrow pits excavated at the edge of the upland southeast of the town of Accomac.

Facies F.-The laminated, horizontal to gently seaward dipping, planar-bedded sands of facies $F$ appear to be typical of both modern and ancient foreshore deposits (Clifton and others, 1971; Clifton, 1969, 1981; Kraft and John, 1979; Thompson, 1937). Laminated sand having high concentrations of black heavy minerals and abundant amphipod burrows is characteristic of the subaerially exposed berm and upper-beach areas of the foreshore. The long, continuous, seaward-dipping planar beds with scattered small-scale ripples and crosslaminations, which are beautifully exposed in a sand pit near Persimmon Point, are typical of the lower beach and nearshore areas (see fig. 13, this report, and the description of inner- and outer-planar structural facies of the swash and surf zones, Clifton and others, 1971, p. 655-658).

Facies G.-The Spisula- and Ensis-dominated molluscan assemblage that characterizes the muddy fine sands of facies $G$ is essentially the same as that found along the shallow nearshore shelf just seaward of the present-day barrier-island complex that parallels the Virginia coast (Michael Castagna, oral commun., 1971). Ostracode and miliolid assemblages obtained from the muddy sands at the Joynes Neck (A-15) and Locustville (A-16) borehole localities also indicate a shallow, normal-marine depositional environment and thus support the interpretation based on the mollusk data (R.M. Forester, written commun., 1976). Therefore, it is inferred that the fine muddy sediments of facies $G$ were deposited along the shallow, innermost margin of the shelf in early Omar time and were subsequently buried by facies $\mathrm{E}$ and $\mathrm{F}$ deposits during southward progradation of the Accomack barrier spit.

\section{Vertical and Lateral Facies Succession}

Transgressive barrier sequence.-The vertical sequence of sedimentary facies in boreholes penetrating the Accomack Member of the Omar Formation in northern Accomack County (see fig. 16) commonly consists of, from bottom to top, (1) a basal gravelly sand (facies A) of the Accomack overlying an irregular erosion surface on the Pliocene Yorktown Formation, (2) peat and brownish-gray mud and sand (facies B) deposited in salt marsh and marsh fringe environments, (3) highly bioturbated dark gray mud and sand (facies $\mathbb{C}$ ) containing Crassostrea virginica Gmelin typical of the more restricted parts of coastal lagcons, (4) well-bedded silty and clayey sand (facies $\mathbb{D}$ ) containing mixed lagconal and nearshore-shelf faunas characteristic of barrier inlets and adjacent parts of the lagcon with open circulation, and (5) clean, crossbedded, gravelly sand (facies E) deposited in washover fan, tidal delta, and surf zone environments. Locally, the uppermost part of the Acco mack includes laminated, gently seaward inclined, planar-bedded sand (facies $\mathbb{F}$ ), which is characteristic of berm and beach-face areas of the foreshore. In conformity with Johannes Walther's law of facies succession (Middleton, 1973), the vertical juxtaposition of sedimentary facies in the Accomack barrier-lagcon complex, as seen in cross section, is similar to the horizontal distribution of facies observable in a traverse from land 


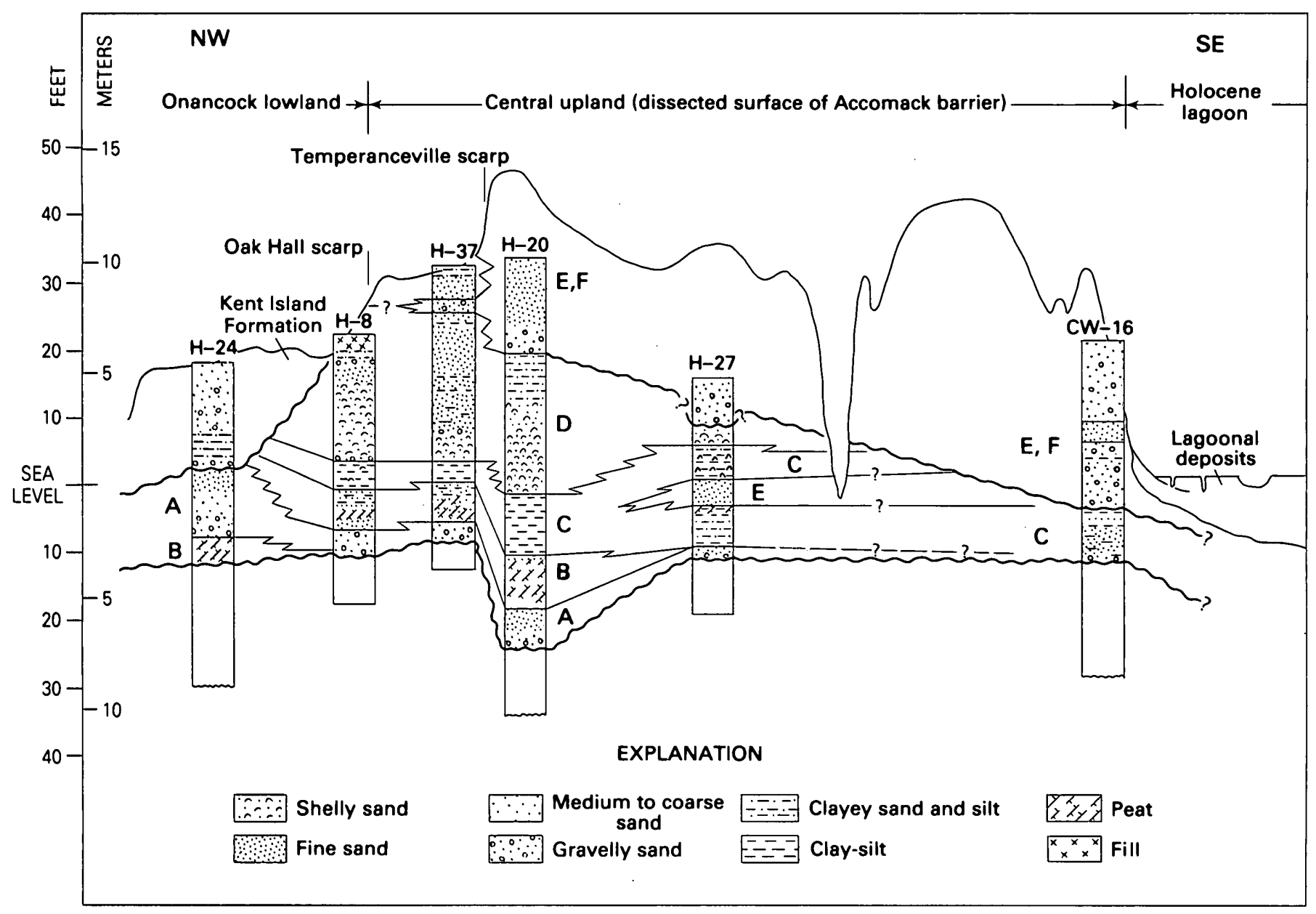

FIGURE 16.-Cross section showing lateral and vertical facies succession in transgressive barrier-backbarrier complex constituting the Accomack Member in northern Accomack County, Va. Stratigraphic section includes westward-thinning, clean, crossbedded barrier sand (facies E, F; see text) and the conformably to unconformably underlying backbarrier and barrier-inlet deposits (facies B, C, D). Facies A includes basal lag and channel gravels. Borehole localities shown on plate 2.

to sea across the modern barrier system of the Atlantic coastal zone. As is the case in the modern barrier system, the Accomack beds in this area generally coarsen upward because of the landward migration in Accomack time of gravelly barrier sands over finer grained deposits of the marsh and lagoon. Although coarsening-upward barrier sequences are commonly considered to be regressive in nature, the superposition of barrier sand over marsh and lagoonal deposits rather than nearshore-shelf sand indicates a transgressive sequence (Kraft, 1971; Kraft and John, 1979).

Lateral facies relationships within the Accomack Member of the Omar Formation are also remarkably similar to facies variations within the adjacent Holocene barrier complex. For example, at the eastern edge of the central upland (fig. 16; pl. 2, loc. CW-16), which is inferred to be the most seaward preserved part of the Pleistocene Accomack barrier, the Accomack se- quence is composed of a 40-ft-thick (12-m-thick) unit of clean, crossbedded barrier sand (facies E, F) and a relatively thin [approximately 10-ft-thick (3-m-thick)] unit of clayey and silty lagoonal deposits (facies C). In this area, the Accomack beds overlie a high on the preAccomack erosion surface; thus, the absence of a basal gravelly sand (facies A) and of a peat or peaty sand (facies B) may be explained in part by nondeposition. The section is very similar to that shown in boreholes on the back side of the Delaware barrier complex in a tidaldelta area where thick tidal-delta sand truncates finer sediments of the normal lagoonal facies sequence (Kraft, 1971, fig. 16).

Farther west in Accomack County, in the central and western parts of the upland area (fig. 16; pl. 2, locs. $\mathrm{H}-27, \mathrm{H}-20$ ), the barrier sands become thinner and finer and overlap or interfinger with the muddy lagoonal and barrier-inlet facies (facies B-D). Conversely, the 


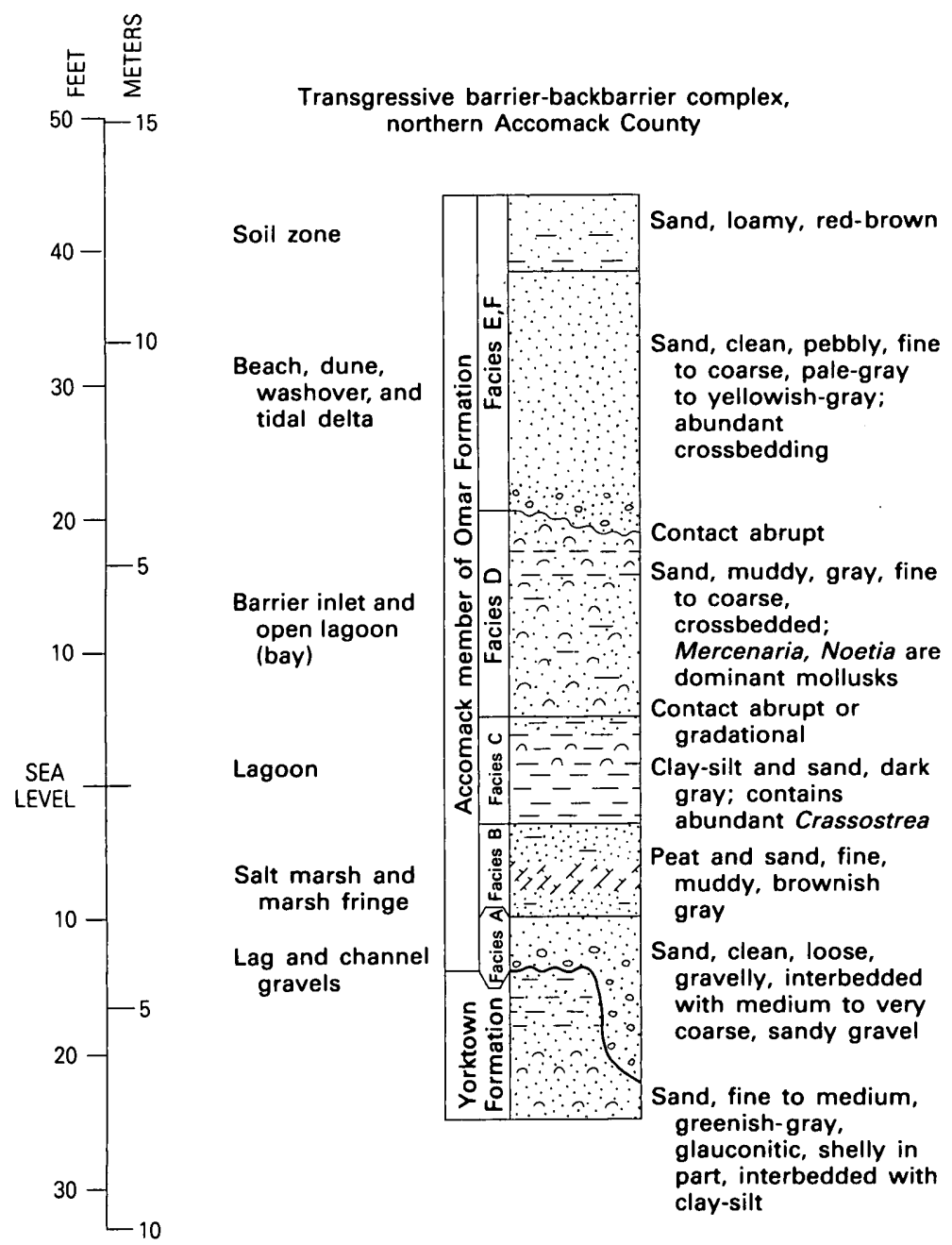

Barrier spit and nearshore-shelf complex, east-central and southern Accomack County

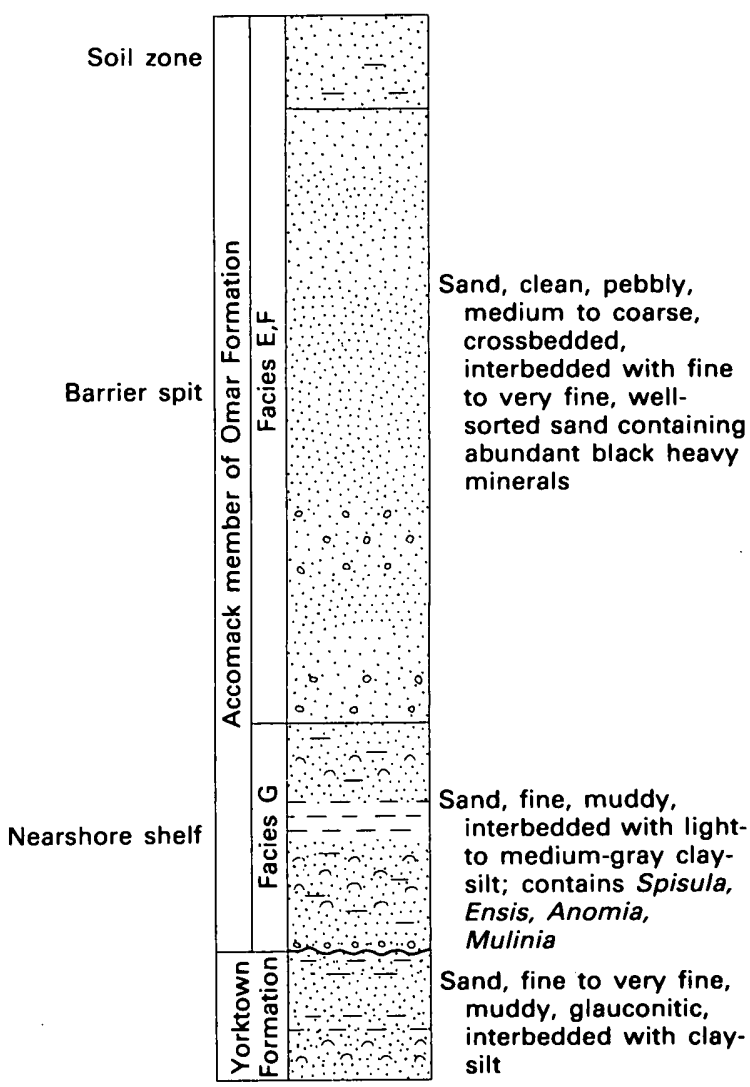

Figure 17.-Vertical facies succession and depositional environments in the Accomack Member in the northern part of Accomack County, Va., compared with those in the central and southern parts of the county.

lagoonal facies thicken westward and commonly form 40-70 percent of the Accomack section in the western part of the central upland area. Locally, west of the Temperanceville scarp, lagoonal and barrier-inlet deposits constitute 90-100 percent of the Accomack (see locs. H-37, H-8).

In summary, the vertical and lateral facies sequences within the Accomack Member of the Omar Formation in northern Accomack County, involving successive onlap of peaty marsh deposits, dark lagoonal mud and sand, and clean, crossbedded barrier sand onto a preAccomack erosion surface, are here considered to form a transgressive barrier system (see also Kraft and John, 1979; Bridges, 1976; Hobday and Orme, 1975).

"Regressive" barrier spit sequence. -In east-central Accomack County, near the town of Accomac, the Accomack Member of the Omar Formation consists, from bottom to top, of (1) a basal sandy gravel or gravelly sand (facies A), commonly about 1-2 ft (.3-6 m) or less in thickness, (2) fine to very fine shelly sand interbedded with clay-silt (facies G), about 10-25 ft (3-8 m) thick, and (3) clean, crossbedded, fine to medium sand, pebbly in part (facies $E, F)$, which is as much as $50 \mathrm{ft}(15 \mathrm{~m})$ in thickness (see fig. 17). The vertical facies sequence, involving the overlap of fine, nearshore-shelf sediments (facies G) by relatively clean, coarse barrier sands (facies $E$ and $F$ ), could be interpreted as a regressive rather than transgressive barrier sequence (LeBlanc and Hodgson, 1959; Kraft and John, 1979). It seems probable, however, that the marked differences in vertical facies succession noted between Accomack Member stratigraphic sections in the northern and central parts of Accomack County are due in large part to differences in paleogeographic setting rather than to a lowering of sea level. The clearly transgressive marsh-lagoonbarrier sequence (facies $\mathrm{A}-\mathrm{F}$ ) in the northern part of the 
county was deposited as the Omar sea transgressed across, and partially bevelled, Tertiary highlands in the vicinity, and to the west, of Hopkins, Bloxom, and Wattsville (see fig. 9). The thicker sections of marsh and lagoonal deposits were preserved in protected areas, such as lows on the Tertiary erosion surface, that were not subjected to the main forces of marine erosion (see, for example, locs. $\mathrm{H}-20, \mathrm{H}-24, \mathrm{C}-2$ in figs. 4, 6, 16). Contemporaneous with the emplacement of the Accomack barrier-lagoon complex, nearshore-shelf sands and muds (facies G) were deposited in an extensive embayed area coincident with a large topographic low extending to the east, south, and southwest of the aforementioned Tertiary highlands. As the transgression progressed, the pebbly sands of the Accomack barrier spit (facies E, F) appear to have prograded southwestward from the highland area across the mouth of the shallow marine embayment, burying the fine, nearshore-shelf deposits (facies G).

\section{Age and Correlation}

Paleomagnetic studies of clay-silt samples from the Accomack Member at two coring sites and three outcrops in the Chincoteague West and Bloxom quadrangles, Virginia, indicate that the Accomack has magnetization of normal paleomagnetic polarity (Liddicoat and Mixon, 1980). The lithology, the virtual lack of change in paleomagnetic direction during demagnetization, and the demagnetization spectra showed no evidence for a stable secondary magnetization. On the basis of the paleomagnetic data and the available U-Th disequilibrium-series ages from the Accomack Member and the correlative Rappahannock River fossil beds (Mixon and others, 1982, p. E7-E11; this report, fig. 7), we assign the Accomack to the Brunhes magnetic inter$\mathrm{val}$, which extends from the present to 0.73 million years B.P. Thus, these data indicate that the Accomack is of middle or late Pleistocene age rather than early Pleistocene as suggested by preliminary amino-acidracemization dating of samples from the Accomack beds in northern Accomack County (Belknap, 1979; Mixon and others, 1982, pl. 1, locs. 2, 3). An upper age limit for the Accomack Member is provided by a carbon-14 age of greater than 40,000 years B.P. obtained from wood from a peat bed in the uppermost part of the Accomack section in southern Accomack County (USGS radiocarbon laboratory number $\mathrm{W}-2544$ ). The peat bed was temporarily exposed in a sand pit $1.2 \mathrm{mi}$ $(1.9 \mathrm{~km})$ due west of Painter, Va. (see pl. 2, loc. Ex-11).

As yet, we have not obtained reliable uranium-series age estimates from the single coral locality that we have found in the Accomack Member. Specimens of a branching coral, Oculina sp.?, from a shallow pit on the mainland west of Chincoteague, Va., gave an apparent ${ }^{230} \mathrm{Th}$ age of $341,000+137,000-66,000$ years B.P. (Mixon and others, 1982, pl. 1, fig. 5, loc. 3). However, because the samples yielded excess ${ }^{230} \mathrm{Th}$ with respect to ${ }^{234} \mathrm{U}$, the calculated age is considered unreliable.

A more reliable ${ }^{230} \mathrm{Th}$ age for the Accomack Member and correlative Pleistocene units in the Chesapeake Bay area was obtained from a specimen of the encrusting coral Astrangia sp. that was collected from fossiliferous strata exposed in wave-cut cliffs along the lower Rappahannock River, west of the bay (Mixon and others, 1982, pl. 1, loc. 14). The Accomack and the Rappahannock River deposits are stratigraphically and geomorphically similar; each unit constitutes a single transgressive-marine sequence, and each unit underlies depositional surfaces ranging from about 40 to $50 \mathrm{ft}$ $(12-15 \mathrm{~m})$ in altitude. The ${ }^{230} \mathrm{Th}$ age from the coral from the Rappahannock River locality suggests that both the Rappahannock River deposits and the Accomack Member represent an interglacial high stand of the sea occurring before the Sangamonian interglaciation (Mixon and others, 1982, p. E7, E13, and E17).

\section{NASSAWADOX FORMATION}

\section{DEFINITION}

The surficial sandy and gravelly deposits of marginalmarine origin that underlie the Franktown plain and the central upland in the area south of the relict Ames Ridge shoreline (pl. 1) constitute a depositional sequence emplaced during a high stand of the sea that probably was separate from and later than the high stand associated with deposition of the Omar Formation as defined by Owens and Denny (1979b). These younger deposits, which range in thickness from about 20 to $200 \mathrm{ft}(6-60 \mathrm{~m})$, are herein named the Nassawadox Formation after exposures and borehole sections near the town of Nassawadox in Northampton County, Va.

\section{General Description}

In the type area in central Northampton County, the Nassawadox beds consist of three mappable lithostratigraphic units, which are herein given member rank and formally named. The lower Stumptown Member is a subsurface lithic unit, as much as $140 \mathrm{ft}(43 \mathrm{~m})$ thick, that consists mainly of muddy fine sand filling a linear paleotopographic low in the erosion surface on the top of the upper Tertiary beds. The trend of the topographic low southeastward across the Delmarva Peninsula and the fluvial to estuarine-marine origin of the sediment fill suggest that the Stumptown beds delineate a major 
paleodrainage, named the Eastville paleovalley (fig. 9), which led from the Chesapeake Bay area to the Atlantic Ocean.

Conformably to unconformably overlying the Stumptown Member is a relatively clean, crossbedded, shelly and gravelly sand unit, as much as $60 \mathrm{ft}(18 \mathrm{~m})$ in thickness, that forms the upper part of the Nassawadox in the southern upland area. This dominantly medium to coarse sand, the Butlers Bluff Member, is thought to have formed as a barrier-spit or shoal complex at the mouth of an ancestral Chesapeake Bay. A related but much finer grained sandy unit, the Occohannock Member, underlies the Franktown plain, which is adjacent to the west of the southern upland. The Occohannock beds, which are generally about $20 \mathrm{ft}(6 \mathrm{~m})$ thick, are interpreted to have been deposited in a large open bay or estuary on the landward (west) side of the barrier formed by the coarser sands of the Butlers Bluff.

TYPE SECTION

The Nassawadox Formation is thickest and most typically developed along the trend of the Eastville paleovalley. Thus, the 200 -ft-thick (60-m-thick) section of the Nassawadox in borehole $\mathrm{Ch}-11$, drilled on the upland surface about $10 \mathrm{mi}(16 \mathrm{~km})$ south-southwest of the town of Nassawadox and near the axis of the paleovalley, is here designated the type section of the formation (pl. 2, loc. Ch-11). The borehole site is at the east end of Route 648 , about $0.5 \mathrm{mi}(0.8 \mathrm{~km})$ east of Stumptown, and west of the Penn Central railroad branch line that connects Cheriton, Nassawadox, and other Delmarva communities (see Cheriton 7.5-min quadrangle).

The Nassawadox beds at this locality constitute one of the thicker Pleistocene sequences in the Middle Atlantic region. Both the estuarine-marine clay-silts and muddy sands of the Stumptown Member and the cleaner, crossbedded barrier sands of the Butlers Bluff Member are typically and fully developed in the borehole section. The Occohannock Member is not present at this locality but is extensively exposed beneath the Franktown plain in the area west of Stumptown and Eastville.

STUMPTOWN MEMBER

Definition

The lower part of the Nassawadox Formation is a sequence of sandy gravel, clay-silt, and muddy fine sand, $140 \mathrm{ft}(43 \mathrm{~m})$ or more in thickness, which fills the Eastville paleovalley (figs. 9, 18). This entirely subsur- face lithic unit is herein named the Stumptown Member of the Nassawadox Formation for borehole sections near Stumptown, Va. The Stumptown beds have been mapped in much of a four-quadrangle area of central and southern Northampton County (see Cheriton, Cape Charles, Franktown, and Nassawadox quadrangles) but are thickest and most completely developed along the axis of the Eastville paleovalley. Seismic reflection traverses in the Chesapeake Bay and in Ramshorn Channel on the east side of the peninsula (pl. 1) indicate that the paleovalley and its sedimentary fill extend from the peninsula area northwestward beneath the bay and eastward beneath the Holocene barrier-lagoon complex into the Cobb Island and Ship Shoal Inlet quadrangle areas. The sands and basal gravels of the Stumptown form a freshwater aquifer that has been tapped by numerous water wells.

Lithology and Type Section

The lower $141 \mathrm{ft}(43 \mathrm{~m})$ of the 200 -ft-thick (60-m-thick) type section of the Nassawadox in borehole $\mathrm{Ch}-11$ is the type section of the Stumptown Member (see fig. 18; pl. 2). The upper $59 \mathrm{ft}(18 \mathrm{~m})$ of the Nassawadox section at this locality has been designated a principal reference section for the Butlers Bluff Member.

The Stumptown beds at the type locality are a conformable sequence of three distinct lithofacies (fig. 18, units A, B, and C). A 15-ft-thick (4.5-m-thick) basal gravelly sand (unit A) contains pebbles and small cobbles of gneiss and schist in addition to the quartz-chertsandstone-quartzite rock suite that is typical of Quaternary beds in the southern Delmarva area. The gravelly sand, which probably represents channel deposits of fluvial origin, is unconformable on uppermost Miocene clay-silt of the Eastover Formation and glauconitic sand and clay-silt of the Pliocene Yorktown Formation.

The basal gravelly sand is overlain by about $20 \mathrm{ft}$ $(6 \mathrm{~m})$ of gray clay-silt (fig. 18, unit B), which contains abundant fragmentary plant material but no ostracodes or foraminifers. The fineness of sediment, abundance of plant material, paucity of fauna, and paleogeographic setting suggest deposition in a restricted estuarine environment.

The middle and upper parts of the Stumptown Member are a monotonous sequence of fine to very fine, medium-gray to greenish-gray sand (fig. 18, unit C), which contains variable amounts of clay and silt. The lower part of the muddy sand contains a very sparse ostracode fauna, benthic foraminifers (Elphidium sp.), juvenile forms of a few bivalve and gastropod species, fish teeth, crab chelae, echinoid spines, and barnacle fragments. Bivalves and gastropods become much more. 
$D$

KILOMETERS

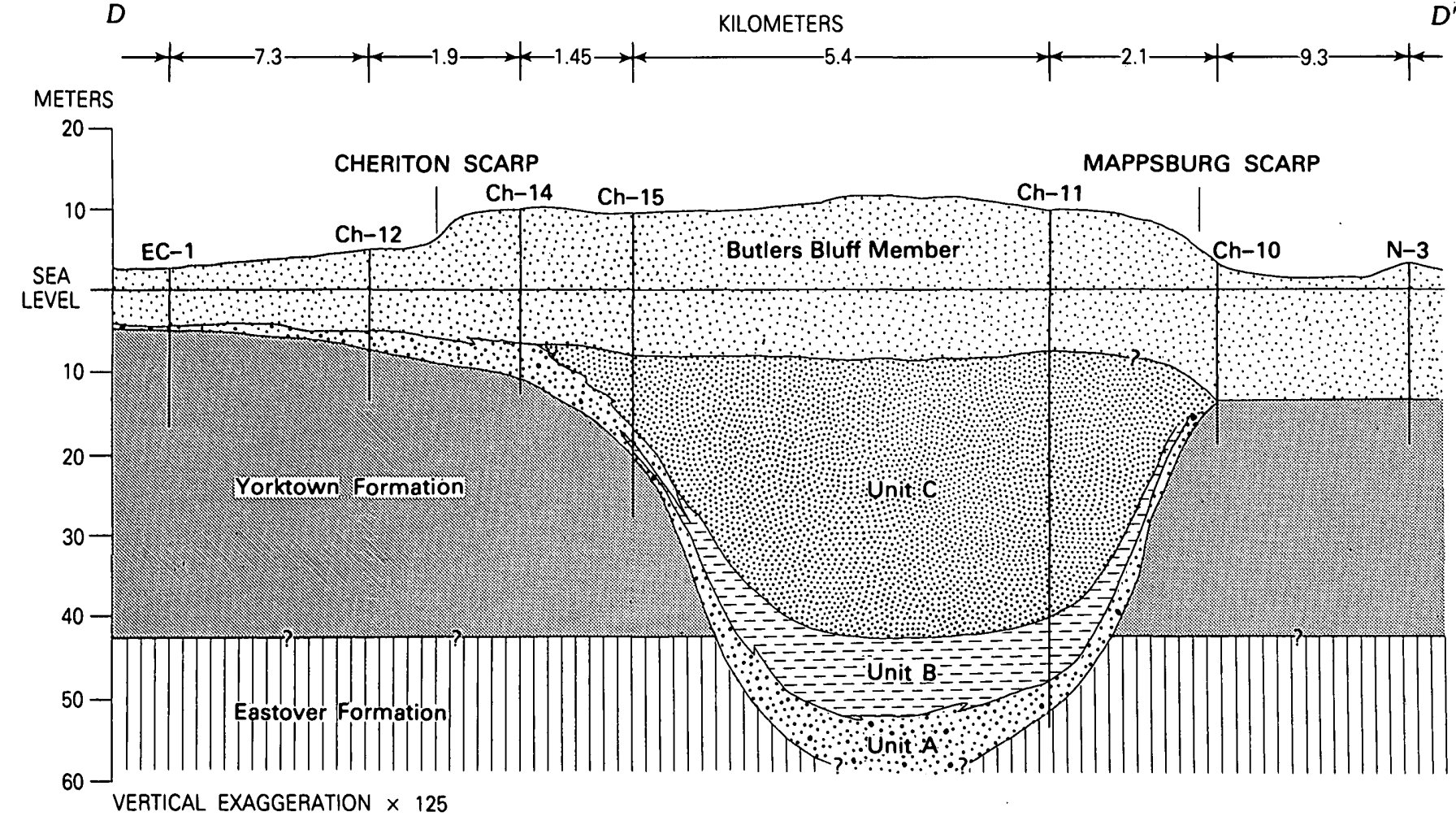

Nassawadox Formation

EXPLANATION

Butlers Bluff Member and Occohannock Member

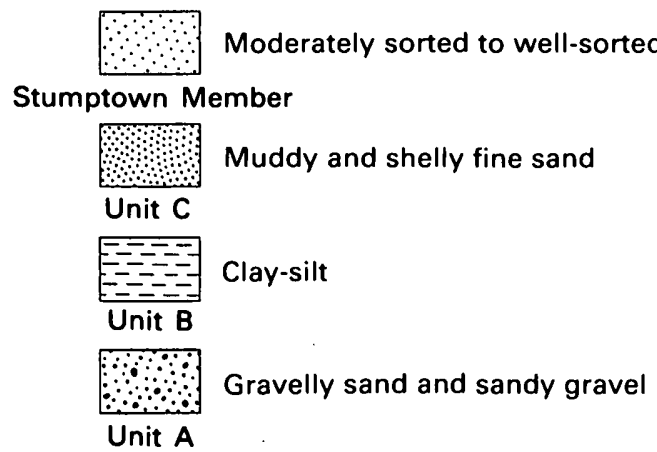

Figure 18.-Generalized cross section showing the lithology and thickness of Pleistocene deposits in the vicinity of the Eastville paleovalley, southern Northampton County, Va. The section includes the thick, muddy paleovalley fill (units A, B, and C of the Stumptown Member of the Nassawadox Formation) and the overlying, better sorted marginal-marine beds (Butlers Bluff and Occohannock Members of the Nassawadox Formation). Line of cross section and borehole locations are shown on plate 2.

abundant in the middle and upper parts of the unit, but species diversity remains low. The most abundant and characteristic molluscan species is Mulinia lateralis (Say); juvenile forms of this species are much more abundant than adults. The low overall species diversity, the great preponderance of juvenile over adult forms in the molluscan assemblage, and the lack of molluscan species characteristic of normal marine salinities (for example, Spisula, Ensis, Donax) indicate that much of the muddy sand unit represents a restricted environment (bay or estuary mouth?) strongly influenced by fresh water. 
Stratigraphic Relationships

In most areas the Stumptown Member unconformably overlies shelly glauconitic sand and silt of the Yorktown Formation. However, along the axis of the Eastville paleochannel in the Cheriton quadrangle (fig. 18, loc. $\mathrm{Ch}-11$ ), where the Yorktown beds are missing as the result of erosion, the Stumptown Member directly overlies uppermost Miocene silt and sand of the Eastover Formation. North of the Eastville paleovalley in the northern and eastern parts of the Franktown quadrangle, where the Stumptown Member is thinner, the Stumptown beds unconformably overlie an unnamed clay-silt unit of Pliocene(?) age that is locally present above the Yorktown.

At the type locality near Stumptown, the upper part of the Stumptown Member (fig. 18, unit C) is overlain by the much coarser, relatively clean sand and gravel of the Butlers Bluff Member of the Nassawadox Formation. Here the contact between the Stumptown and the Butlers Bluff is abrupt but appears to be conformable. At some localities, however, the base of the Butlers Bluff Member is marked by a pebbly sand as much as $2 \mathrm{ft}(0.6 \mathrm{~m})$ in thickness, suggesting that at least locally the contact between the Butlers Bluff and the underlying Stumptown may be erosional (see pl. 2, borehole locs. F-30, F-31, F-33 in the Franktown quadrangle).

Butlers Bluff MEMber

Definition

The 60-ft-thick (18-m-thick) unit of clean, crossbedded, fine to coarse sand and gravel that directly underlies the southern Delmarva upland and that conformably to disconformably(?) overlies the muddy Stumptown beds is herein described as the Butlers Bluff Member of the Nassawadox Formation. The Butlers Bluff is easily distinguished from the underlying Stumptown Member by its relative cleanness and coarseness, its better sorting, and the greater diversity of its fossil fauna. In the subsurface, the Butlers Bluff Member extends westward beneath the Franktown plain where it is thinner and is overlain by the finer sands of the Occohannock Member.

\section{Lithology and Type Section}

The Butlers Bluff Member is named for the extensive exposures in wave-cut cliffs along Chesapeake Bay near the southern tip of the Delmarva Peninsula. The 25- to 30-ft-thick (7.5- to 9-m-thick) section of pale-gray to light yellowish gray, fine to coarse pebbly sand at
Butlers Bluff between Picketts Harbor and the old Penn Central railroad ferry landing is designated the type section of the member (fig. 19). All calcareous fossils have been leached from these beds, but molluscan and crustacean burrows of several types and ghosts of the surf clam Spisula solidissima and of other bivalves indicate a marginal-marine depositional environment (fig. 20). Trough-crossbedding, including large-scale crossbeds of the festoon type, is the most conspicuous sedimentary structure. Crossbedding dips are multidirectional, but the general dip of the more continuous strata is southward.

Only the upper part of the Butlers Bluff Member is exposed in the cliffs at the type locality and in borrow pits and roadcuts elsewhere in Northampton County. Thus, boreholes that completely penetrate the member in the central upland area provide important reference sections showing vertical and lateral variations in lithology (see pl. 2, locs. T-15 near Cape Center, Ch-11 near Stumptown, and F-30 near Machipongo).

Lithically, in the exposures at the type locality and the subsurface reference sections, the Butlers Bluff consists of two interstratified sediment types that are very similar to facies $\mathrm{E}$ and $\mathrm{G}$ of the Accomack Member of the Omar Formation. Poorly sorted, medium to very coarse pebbly quartz sand like that of facies $\mathrm{E}$ is commonly dominant in the upper Butlers Bluff Member, especially in the eastern and central parts of the upland. Relatively well sorted, fine to medium quartz sand containing abundant black heavy minerals (like facies G) generally predominates in the middle and lower parts of the Butlers Bluff. Locally, however, the basal 10-12 ft $(3-4 \mathrm{~m})$ of the unit is medium to coarse gravelly sand. In the lower Butlers Bluff, fine to coarse shelly sand containing abundant large mollusks forms a distinctive and widespread lithic subunit that can be traced from the upland area westward beneath the Franktown plain.

\section{Fauna}

Both the moderately well sorted fine sand and the poorly sorted coarse pebbly sand components of the Butlers Bluff Member in southern Northampton County contain an abundant and fairly diverse molluscan and ostracode fauna (B. W. Blackwelder, written commun., 1973, 1978; J. E. Hazel, written commun., 1973). A partial list of mollusks from borehole localities $\mathrm{Ch}-11$, EC-1, and T-15 includes

Marginella apicina (Menke)

Mulinia lateralis (Say)

Nassarius trivittatus (Say)

Nassarius sp. cf. N. obsoletus (Say)

Spisula sp.

Ensis sp. 


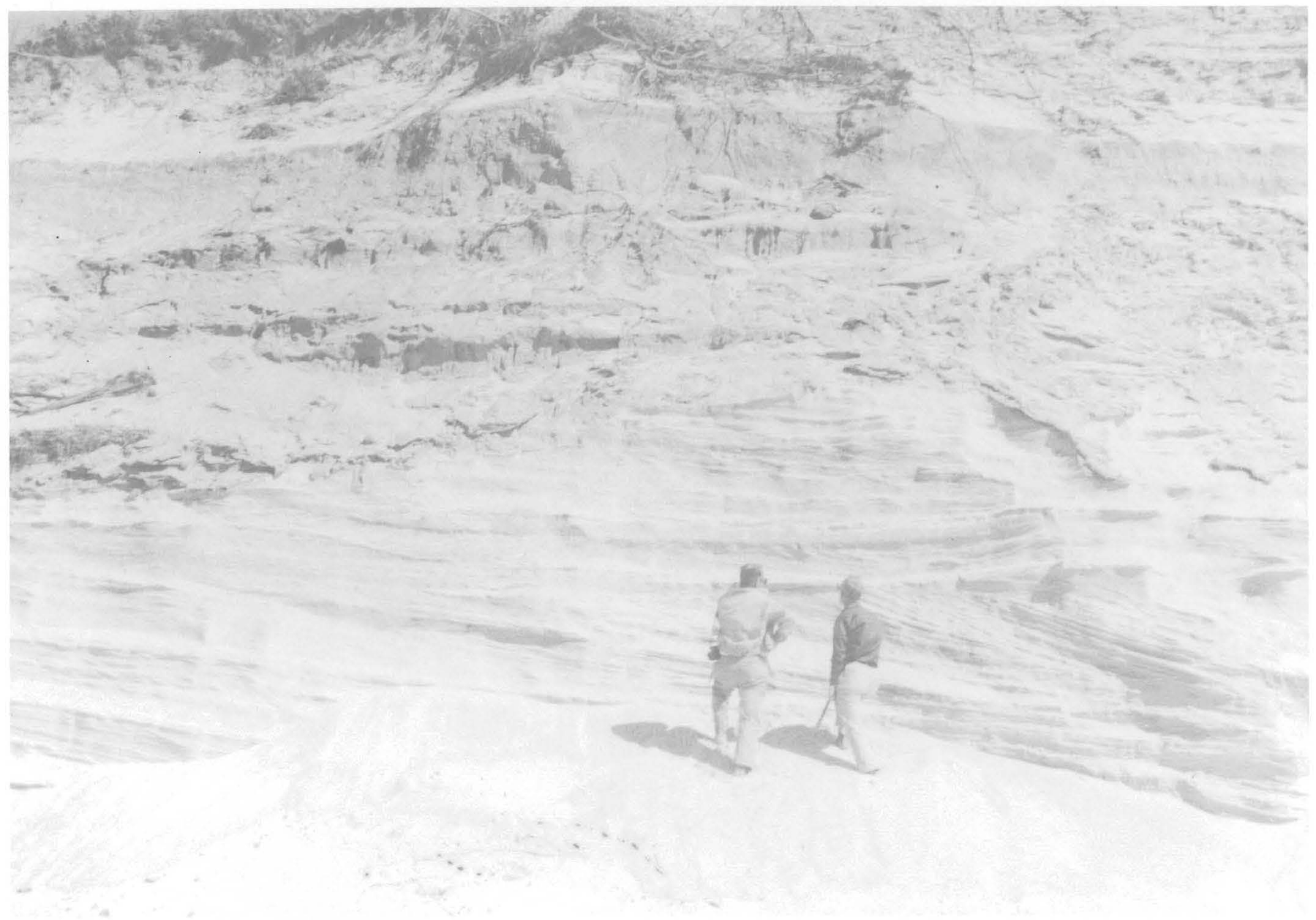

FiguRE 19.-Highly leached, crossbedded sands of the Butlers Bluff Member of the Nassawadox Formation in wave-cut cliffs at the Butlers Bluff locality, southern Northampton County. Darker, more resistant bed in upper part of exposures is sandy loam of the soil horizon. White sands above soil zone are eolian (dune) deposits, which appear to be derived from the narrow beach below.

Divaricella sp.

Pleuromeris tridentata (Say)

Eupleura sp.

Olivella sp. cf. O. mutica (Say)

Petricola? sp.

Polinices sp.

Acteocina canaliculata (Say)

Gemma gemma (Totten)

Pandora? sp.

Busycon sp.

Caecum sp.

Cardita tridentata (Say)

Retusa canaliculata (Say)

Crassinella lunulata (Conrad)

Mulinia, Nassarius, Retusa, and Spisula are locally common to abundant.

The ostracode assemblage, from borehole samples at locality EC-1 in the Elliotts Creek quadrangle, includes the following species:

\author{
Pseudocytheretta edwardsi (Cushman) \\ Cushmanidea seminuda (Cushman) \\ "Haplocytheridea" bradyi (Stephenson) \\ Pontocythere n. sp. \\ Sahnia n. sp.
}

Paleoenvironment

The mollusks Pleuromeris tridentata, Olivella sp., and Marginella apicina presently live to the south of Cape Hatteras and are not known to range northward (B. W. Blackwelder, written commun., 1978). Thus, the presence of these species suggests warmer water than is presently found off the coast of Virginia. The mollusk and ostracode assemblages and the sea urchin plates suggest a shallow $(<10 \mathrm{~m})$, nearshore-shelf depositional environment with normal or near normal salinities. 

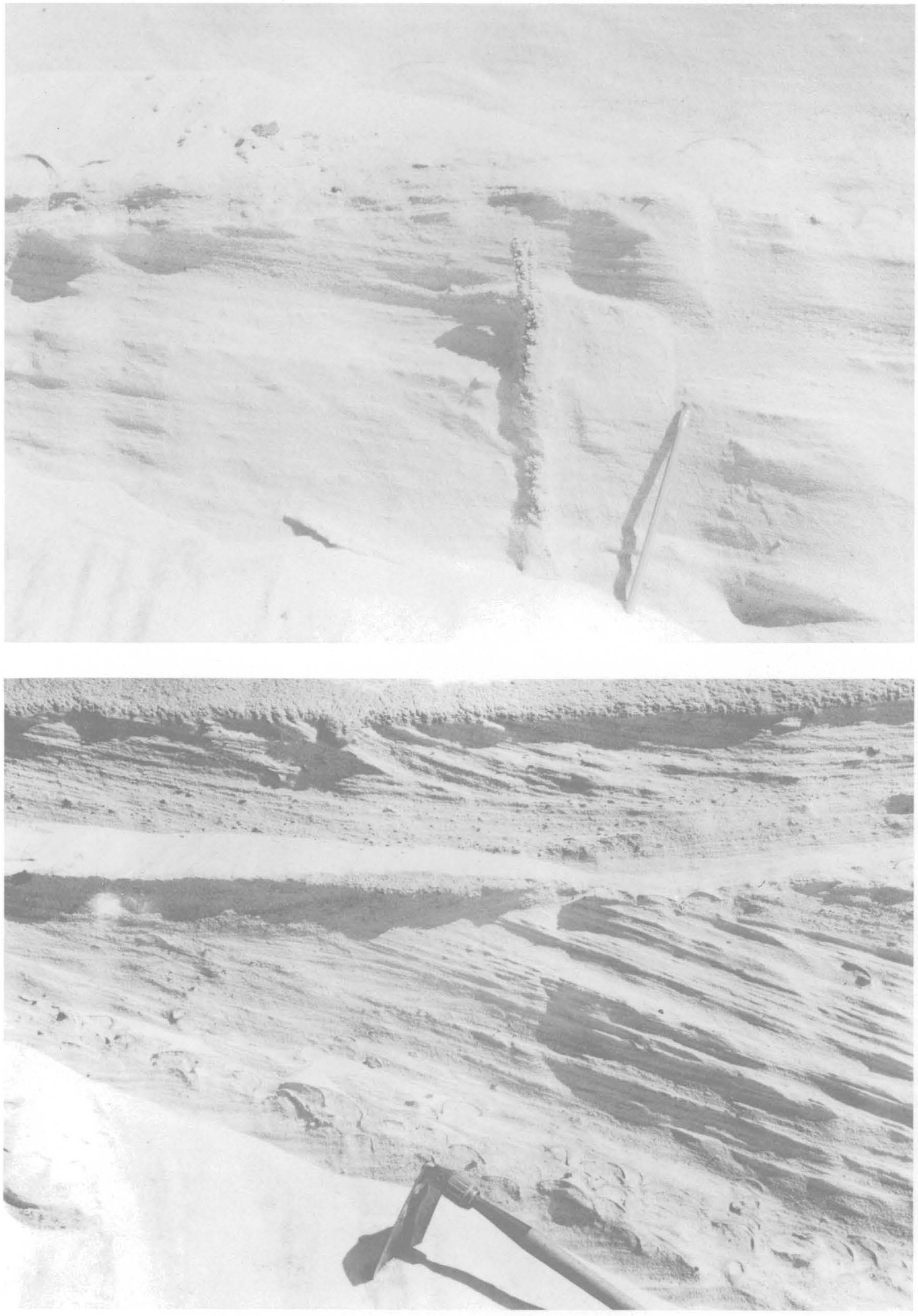

FiguRE 20.-Fossils in highly leached sands of the Butlers Bluff Member of the Nassawadox Formation at Butlers Bluff, Va. Top, cast of noded Ophiomorpha burrow is similar to that of the burrowing shrimp, Callianassa major. Bottom, convex-upward ghosts of surf clam, Spisula solidissima, alined along crossbeds of medium to coarse pebbly sand. 
Paleogeography

The origin of the Butlers Bluff Member as a southward-building complex of spit-platform sands and very shallow shoals is suggested by (1) the coarse grain size of much of the sediment composing the Butlers Bluff, (2) the coarsening-upward sequence, (3) the marine faunas, (4) the generally southward-inclined bedding exposed in the wave-cut cliffs at the south end of the peninsula, and (5) the southward decrease in altitude of the Nassawadox depositional surface in the southern part of the Townsend quadrangle area.

OCCOHANNOCK MEMBER

Definition

A sequence of light yellowish gray, fine to medium quartz sand, commonly about 7-20 ft (2-6 m) thick, constitutes the surficial deposits of the Franktown plain in western Northampton County (see pl. 1). These beds are herein named the Occohannock Member of the Nassawadox Formation for exposures in wave-cut cliffs along Occohannock Creek, a small tidal stream that forms the boundary between Northampton and Accomack Counties on the west side of the Delmarva Peninsula. The Occohannock Member disconformably overlies the Accomack Member of the Omar Formation and disconformably to conformably overlies the Butlers Bluff Member of the Nassawadox. Along the Pungoteague scarp, which forms the western side of the Franktown plain in the Jamesville and Exmore quadrangle areas, the Occohannock Member is truncated in part and overlapped by younger Pleistocene beds of the Kent Island Formation. The Occohannock beds are readily distinguished from the strongly trough-crossbedded, gravelly barrier sands of the adjacent Accomack and Butlers Bluff by (1) the relatively fine grain size of the sand fraction, (2) the greater abundance of clay-silt both as matrix and as discrete beds, and (3) the dominantly massive to horizontally bedded nature of the sandy strata as observed in outcrop sections. In contrast, the Occohannock beds are very similar lithically to the Kent Island Formation (described below).

Type and Reference Sections

Type section.-The exposures in the west-facing cliff at the mouth of Shields Cove on the north side of Occohannock Creek, about $2.5 \mathrm{mi}(4 \mathrm{~km})$ due west of Bell Haven, are designated the type section of the Occohannock Member (pl. 2). The exposed cliff section includes the Occohannock beds, about $15 \mathrm{ft}(4.5 \mathrm{~m})$ thick, and an underlying unit of medium to coarse sand, about $8 \mathrm{ft}$ $(2.5 \mathrm{~m})$ thick, that is probably assignable to the Accomack Member of the Omar Formation (fig. 21). The basal bed of the Occohannock is pebbly sand, 4-12 in $(9-28 \mathrm{~cm})$ thick, that fills low areas on the irregular surface of the underlying coarser barrier sand unit. The lower and middle parts of the Occohannock are fine to medium sand in beds $2-18$ in $(5-42 \mathrm{~cm})$ thick. A few sand beds show indistinct, small-scale crossbedding. Some clay and silt are present as laminae, disk-shaped pebbles, and matrix material. Brown bands of ironoxide cemented sand that parallel bedding planes emphasize the dominantly horizontal bedding at this locality. Ghosts of small to medium-sized bivalves that occur about $7 \mathrm{ft}(2 \mathrm{~m})$ above the base of the unit are the only fossils observed in the type section.

The uppermost $5 \mathrm{ft}(1.5 \mathrm{~m})$ of the Occohannock beds at the type locality is gravelly and sandy loam of the soil zone. The coarseness of this unit suggests that it may represent a regressive phase of the generally finegrained Occohannock Member.

Reference sections.-Well-exposed reference sections include the wave-cut cliffs on the south bank of Occohannock Creek about $0.8 \mathrm{mi}(1.3 \mathrm{~km})$ northwest of Wardtown (Jamesville quadrangle), the cliffs at Shooting Point on the Chesapeake Bay just south of the mouth of Nassawadox Creek (Franktown quadrangle), and the cliffs on the Chesapeake at the south end of Hungars Beach (northwest corner of the Cheriton quadrangle).

Stratigraphic Relationships

A 2- to 12-in-thick (5- to 30-cm-thick) pebble bed at the base of the Occohannock section, mapped in outcrop through much of the Exmore, Jamesville, and Franktown quadrangle areas, suggests a disconformable relationship between the Occohannock and the underlying Accomack Member of the Omar Formation in northern Northampton County. To the southwest, in the downdip direction, where the available data consist mainly of borehole samples, relationships between the Occohannock beds and the Butlers Bluff Member of the Nassawadox are not entirely clear. In some of the borehole sections in this area, the lack of evidence for a break in deposition betweeen the two units, such as a basal pebble bed or an abrupt change in lithology, suggest that the Occohannock may conformably overlie the Butlers Bluff in downdip areas. Alternatively, the Occohannock beds might be a western equivalent, at least in part, of the fine, well-sorted sand lithofacies that composes much of the middle and lower parts of the Butlers Bluff Member of the Nassawadox. 


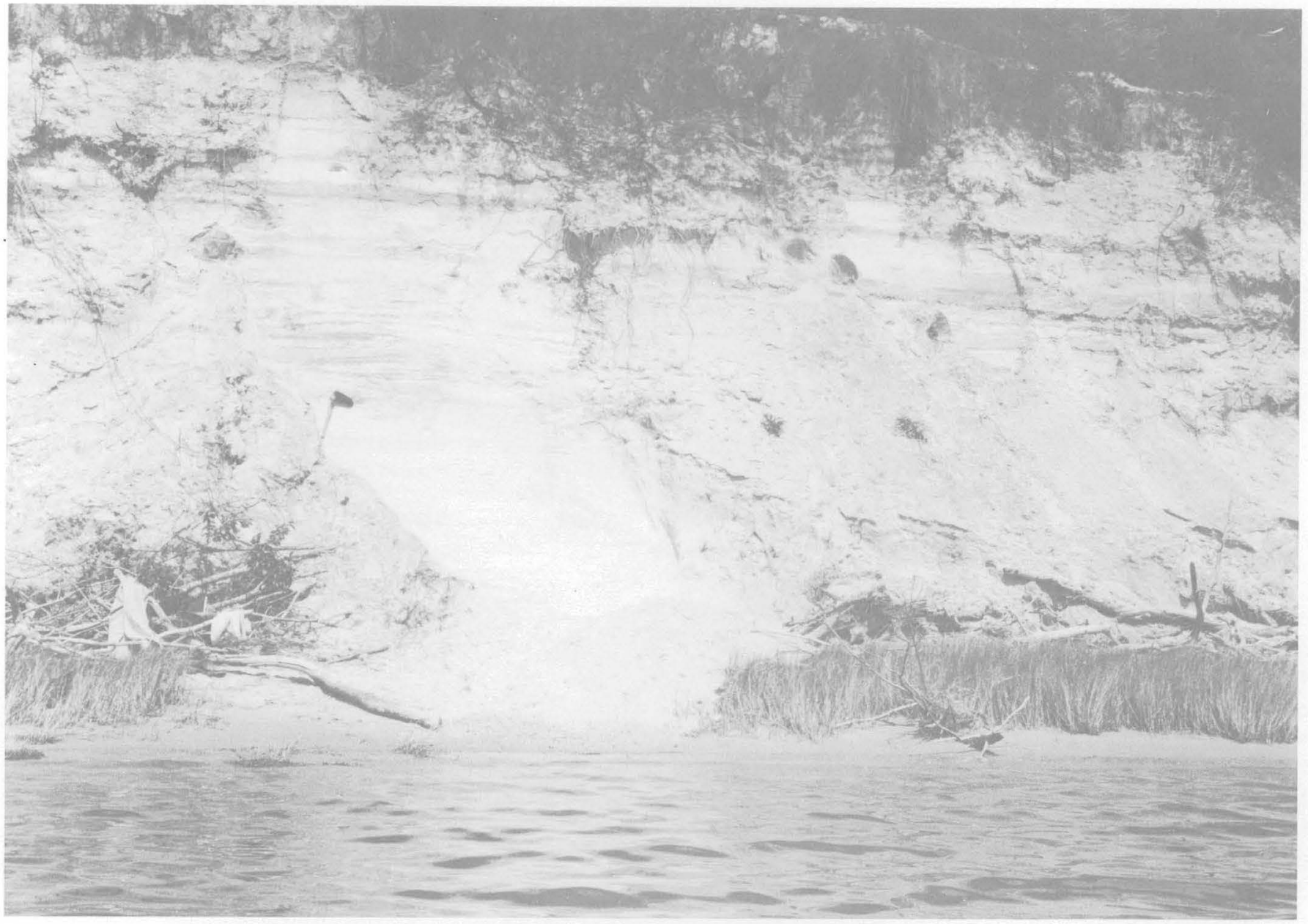

FIGURE 21.-Type section of the Occohannock Member in low cliffs on north side of Occohannock Creek about $2.5 \mathrm{mi}(4 \mathrm{~km})$ west of Bell Haven, Va. Head of shovel is at basal pebble bed of the dominantly horizontally bedded Occohannock sequence. Sands in lower part of exposure probably represent facies $\mathrm{E}$ of the Accomack Member of the Omar Formation.

Paleoenvironment and Paleogeography

Because of the very poor preservation of the mollusks and other fossil faunas and the lack of palynological data, no biostratigraphic or paleoclimatic comparisons between the Occohannock beds and other Delmarva lithostratigraphic units can be made at this time.

The relatively fine size of the dominant sediment type (fine to very fine sand), the relative abundance of claysilt compared to the barrier sands of the Butlers Bluff, and the dominance of massive and horizontally bedded strata indicate a low-energy depositional environment. The quiet-water environment, in conjunction with the southwestward-sloping depositional surface and the position of the Occohannock to the west of the Nassawadox barrier spit, suggest that the Occohannock beds are "bay-bottom" sediments that were deposited contemporaneous with the development of the Nassawadox spit or shortly thereafter.

\section{Correlation}

On the basis of similar stratigraphic and geomorphic positions within the Pleistocene marginal-marine sequences on each side of Chesapeake Bay, the Occohannock beds have been correlated with the Sedgefield Member of the Tabb Formation of Johnson (1976), which has been mapped to the west of the bay in the peninsula area between the lower James and York Rivers (Johnson, 1976; Mixon and others, 1982, fig. 3). Like the Occohannock beds, the Sedgefield is a thin sandy unit of marginal-marine origin that underlies depositional surfaces averaging 20-30 ft $(6-9 \mathrm{~m})$ in altitude.

The Occohannock Member probably also correlates, at least in part, with the Kempsville beds of the Norfolk, Va., area on the south side of Chesapeake Bay (Oaks and Coch, 1973; Mixon and others, 1982). 


\section{SURFICIAL DEPOSITS OF ONANCOCK LOWLAND}

\section{KENT ISLAND FORMATION}

Geomorphic SetTing and Definition

For much of its length in Maryland and Virginia, the western part of the Delmarva Peninsula is a broad lowland that slopes very gently toward the Chesapeake Bay. This lowland, nearly $125 \mathrm{mi}(200 \mathrm{~km})$ long and as much as $30 \mathrm{mi}(48 \mathrm{~km})$ wide, is separated from the higher terrain of the central Delmarva upland by low but conspicuous west-facing scarps (pl. 1). The nearly flat to very gently rolling surfaces of the main interfluve areas range upward in altitude from sea level at the shoreline of Chesapeake Bay to $15-20 \mathrm{ft}(4.5-6 \mathrm{~m})$ or slightly more at the toe of the bounding scarps. The bayward slope and flatness of the lowland surface, the nature of the underlying sandy and silty sediments, and the relationship to similar lowlands adjacent on the west side of Chesapeake Bay suggest that the Delmarva lowland is part of a relict topographic basin once occupied by an estuary even more extensive than the present Chesapeake Bay.

The surficial sandy, silty, and clayey deposits of latest Pleistocene age that underlie the western Delmarva lowland constitute the Kent Island Formation as defined by Owens and Denny (1979b, p. A24-A26). The formation was named for the excellent exposures in low bluffs on the north side of Kent Island at the junction of the Chester River estuary with the main Chesapeake Bay in Queen Annes County, Md. At the type locality, the Kent Island beds are about $40 \mathrm{ft}(12 \mathrm{~m})$ thick, but they thin eastward to a feather edge in the vicinity of the scarp at the eastern margin of the lowland.

\section{Depositional Surface}

The surface of the western Delmarva lowland in Virginia, herein referred to as the Onancock lowland (pl. 1 ), is considered to closely approximate the original depositional surface that existed during the later stages of deposition of the Kent Island beds. On the basis of subtle geomorphic differences, the Onancock lowland can be divided into northern and southern parts, which may relate to variations in thickness of the Kent Island and, indirectly, to differences in erodibility of lithic units directly underlying the Kent Island.

Northern Onancock lowland.-The northern part of the Onancock plain, which extends from the Pocomoke River southwestward to the vicinity of Onancock, is quite similar to the corresponding geomorphic surface in Maryland (Owens and Denny, 1979a,b) but is somewhat narrower. The less dissected interfluve areas are broad, very gently westward sloping surfaces marginal to the Pocomoke Sound. The sound itself is a wide shallow arm of Chesapeake Bay formed by inundation of the lower Pocomoke River drainage basin during the general rise of sea level in Holocene time. The continued relative rise in sea level in the late Holocene and the consequent reflooding of the Onancock plain has formed extensive marshlands as much as $2 \mathrm{mi}(3 \mathrm{~km})$ in width. In this area are found gently curving sand ridges, standing 3-6 $\mathrm{ft}(1-2 \mathrm{~m})$ above the surrounding marshland, which are similar to Carolina Bay rims and, thus, may be "islands" of Pleistocene sediment protruding through a thin veneer of Holocene marsh deposits (see Parksley and Saxis 7.5-min quadrangles).

In northern Accomack County, the Onancock plain is bordered on the east by the Oak Hall scarp, the base of which is at an altitude of about $20-25 \mathrm{ft}(6-7.5 \mathrm{~m})$. In the vicinity of the towns of Oak Hall and Hallwood, the scarp is a conspicuous feature that makes a sharp boundary between the lowland plain and the central upland. To the south near Parksley, the Oak Hall scarp is less distinct, in part because the westward slope of the Onancock plain is interrupted by a series of long, narrow sand ridges that are adjacent to the scarp on the west (pl. 1). At Parksley the ridges trend southwestward, parallel to the Oak Hall shoreline. Farther south, however, the ridge trend flares slightly to the westsouthwest toward the modern Chesapeake Bay shoreline. These features are thought to be relict beach-dune ridges that mark successively lower stands of the sea during the drop in sea level that occurred after the last interglacial period. These ridges appear to be similar in origin to the Bell Neck sand ridge complex on the east side of the peninsula and probably formed at about the same time.

Southern Onancock lowland.-South of Onancock the lowland narrows gradually, and, at Silver Beach in Northampton County, it is truncated by an actively eroding segment of the modern Chesapeake Bay shoreline. In this area, the average altitude of the Onancock plain appears to be somewhat lower than it is north of Onancock. Likewise, the toe of the west-facing Pungoteague scarp at the lowland's eastern edge is only about $15 \mathrm{ft}(4.5 \mathrm{~m})$ above sea level, which is distinctly lower than altitudes of scarp toes north of Onancock (compare, for example the Oak Hall scarp in the Hallwood quadrangle area). The southern part of the Onancock plain has no Carolina Bays and few, if any, relict beach ridges. 
LiThOLOGY, THICKNESS, AND STRATIGRAPHIC RELATIONSHIPS

In Virginia the Kent Island strata are very poorly exposed except for a few outcrops in low, wave-cut banks along small tidewater streams such as Nandua, Pungoteague, and Onancock Creeks. Thus, the lithic and stratigraphic descriptions given in this section are based mainly on borehole data.

Area north of Onancock.-In the northwestern part of Accomack County, Va., and the southernmost part of Somerset County, Md., the Kent Island Formation ranges in thickness from about 3 to $20 \mathrm{ft}(1-6 \mathrm{~m})$. Here the lower part of the Kent Island is coarse to very coarse gravelly sand composed mainly of quartz and chert. Spoil piles at the numerous borrow pits and irrigation ponds excavated in the Kent Island contain abundant cobble-and boulder-sized sandstone and quartzite and lesser amounts of schist and gneiss. The coarseness of this material suggests that the basal beds of the Kent Island in this area are lag deposits reworked from the Accomack Member of the Omar Formation and the older gravel sheets of southern Maryland (Owens and Denny, 1979b). The middle and upper parts of the Kent Island are typically poorly sorted, clayey and silty, fine to medium gray sand. Locally, as in the west-central part of the Hallwood quadrangle and the eastern Saxis quadrangle areas, the middle and upper Kent Island includes peat as much as $2 \mathrm{ft}(0.6 \mathrm{~m})$ in thickness (loc. H-38) and well-sorted yellowish-gray sand (locs. H-25, H-32, S-9).

In the shallow subsurface of the northern Onancock plain, the Kent Island Formation commonly unconformably overlies older Pleistocene beds of the Accomack Member of the Omar Formation (pl. 2). However, over highs on the erosion surface at the top of the Tertiary section, the Kent Island directly overlies the Eastover and Yorktown Formations (for example, at locs. C-4, P-11, B-29, H-23, S-5). The Kent Island is easily distinguished from the finer grained, more consolidated glauconitic sands and silts of the Tertiary section but is lithically similar to the Accomack Member of the Omar. In general, however, the basal beds of the Kent Island are coarser and more poorly sorted than the directly underlying Accomack deposits and, on the basis of the borehole data, are interpreted to have truncating relationships with that unit.

Area south of Onancock.-To the south of Onancock, the uppermost $10-20 \mathrm{ft}(3-6 \mathrm{~m})$ of the Kent Island typically consists of moderately well sorted to wellsorted, fine to medium, yellowish-gray quartz sand. Faint cross lamination, as shown by black heavy minerals, is the most common bedding structure observed in outcrop sections. In general, the deposits are finer grained and better sorted than the Kent Island strata north of Onancock.
In the Pungoteague, Exmore, and Nandua Creek quadrangle areas west and south of Onancock, the fine, well-sorted sands of the upper Kent Island grade downward into gray to grayish-orange, medium to coarse pebbly sand as much as $15 \mathrm{ft}(4.5 \mathrm{~m})$ thick that disconformably overlies backbarrier and channel-fill deposits of the Accomack Member of the Omar Formation. Thus, the Pleistocene section in this part of the Onancock lowland area appears to consist of two fining. upward sequences, the Kent Island Formation and the Accomack Member of the Omar.

At the Underhill Creek and Scarborough Neck localities (see pl. 2, locs. PT-8 and J-24 in the Pungoteague and Jamesville quadrangles), the wellsorted fine sands of the upper Kent Island appear to grade downward into clayey and silty shelly sands, about 10-20 ft (3-6 m) thick, which contain abundant mollusks and ostracodes. The ostracode faunas suggest mild-temperate climatic conditions and deposition in shallow marine water; however, the mollusks indicate a more brackish, backbarrier environment. The borehole data suggest that the fossil beds at these localities are equivalent to the extensive shell beds encountered in numerous boreholes in the Butlers Bluff and Occohannock terranes farther south in the Franktown, Cheriton, Cape Charles, Elliotts Creek, and Townsend quadrangle areas (locs, F-30, F-31, Ch-11, Ch-13, Ch-15, CC-1, EC-1). If this correlation is correct, the apparent gradational contact between the fine sands of the Kent Island and the underlying fossil beds at Underhill Creek and Scarborough Neck would indicate that the Kent Island Formation and the Butlers Bluff and Occohannock Members of the Nassawadox were deposited during a single major transgressive-regressive cycle. In accordance with this interpretation, the Pungoteague and Cheriton scarps, which separate the Kent Island, Occohannock, and Butlers Bluff terranes, must have formed as the result of stillstands or minor fluctuations of sea level that were superimposed on the larger transgressive-regressive cycle.

\section{Paleoclimate}

Palynologic studies of samples from the northern part of the Kent Island terrane in Queen Annes and Talbot Counties, Md., suggest that cool-temperate climatic conditions prevailed during deposition of the Kent Island Formation in that area (Owens and Denny, $1979 \mathrm{~b}, \mathrm{p}$. A26). In contrast, the lower and middle parts of the Kent Island at the Doe Creek and Lecato localities in Accomack County, Va., contain pollen assemblages dominated by pine, oak, hickory, chestnut, holly, and cypress (see Parksley and Hallwood quadrangles, locs. P-15, H-38). At Indian Hammock in southern- 
most Somerset County, Md., the Kent Island deposits are barren of pollen but contain fairly abundant needles of cypress or white cedar (Crisfield quadrangle, loc. $\mathrm{C}-2)$. Thus, the pollen data available to date from the Kent Island terrane in Virginia suggest warmtemperate to subtropical climatic conditions, at least during the early part of Kent Island time (L. Sirkin, written commun., 1972-76; T. Ager, written commun., 1979). At present it is difficult to reconcile the apparently conflicting pollen data from the Maryland and Virginia areas. Possibly, the warm-climate pollen assemblages from the south are from deposits representing the early to peak periods of a transgressive depositional phase whereas the cool-climate assemblages are from sediments deposited during a regressive phase associated with a general cooling trend at the beginning of a glacial stage.

\section{AgE AND CORRELATION}

Owens and Denny $(1978,1979 a, b)$ suggested that deposition of the Kent Island encompassed parts of late Sangamon, early Wisconsin, and middle Wisconsin time. The early to middle Wisconsin designation for the upper part of the Kent Island is based on (1) pollen assemblages which suggest cool-temperate climatic conditions, (2) a radiocarbon age of $30,000 \pm 1,000$ years B.P. from a peat bed near Easton, Md., that is thought to be within the upper Kent Island, and (3) a correlation with the Sinepuxent Formation on the ocean side of the Delmarva Peninsula (Owens and Denny, 1979b, p. A25-A26). These workers also believed that the present lowland surface underlain by the Kent Island was formed during the middle Wisconsin and, thus, suggested that sea level in middle Wisconsin time was as much as $15 \mathrm{ft}(4.5 \mathrm{~m})$ above present sea level (Owens and Denny, 1979b, p. A26).

In the Virginia part of the Delmarva, no data have been obtained that support the concept of a high sea level stand in middle Wisconsin time. On the contrary, a warm-temperate pollen assemblage and a radiocarbon age of $>40,000$ years B.P. obtained from a peat bed in the middle part of the thin Kent Island section at the community of Lecato in northern Accomack County (loc. H-38) strongly suggest that, in this area, the Kent Island was deposited during an interglacial stagepresumably the later part of the Sangamon. The Oak Hall scarp, about $0.25 \mathrm{mi}(0.4 \mathrm{~km})$ east of Lecato, must have been cut at about the same time that the peat bed and thin overlying sands were deposited and thus should also be pre-Wisconsin in age. A warm-temperate pollen assemblage was also obtained at depths of 5-6 ft $(1.5-2 \mathrm{~m}$ ) below the surface (at an altitude of sea level to
$-1 \mathrm{ft}$ ) at borehole locality P-15 near Doe Creek in westcentral Accomack County (see Parksley quadrangle):

\section{DEPOSITS BORDERING EASTERN SIDE OF CENTRAL UPLAND}

\author{
JOYNES NECK SAND
}

DEFINITION

The name Joynes Neck Sand is introduced for a surficial sandy unit, as much as $30 \mathrm{ft}(9 \mathrm{~m})$ in thickness, that overlies the Omar and Nassawadox Formations along the eastern side of the Delmarva Peninsula in Accomack and Northampton Counties. In the type area, in the vicinity of Joynes Neck in Accomack County, the lithic unit is areally coextensive with the dissected, seaward-sloping Metomkin plain, which is bordered on the west by the central upland and on the east by the Holocene lagoon (see pl. 1 and the Accomac, Bloxom, and Metomkin Inlet quadrangles). Sandy deposits underlying a similar but somewhat narrower coastal terrace in the southern part of Northampton County have not been studied in detail but are here tentatively included in the Joynes Neck Sand on the basis of similar altitudes of depositional surfaces and similar position relative to the relict shoreline arc that is marked by the Metomkin and Kiptopeke scarps (see pl. 1).

LITHOLOGY

The Joynes Neck Sand is poorly exposed. Borehole data indicate that it consists mainly of loose, fine to coarse, yellowish-gray quartz sand, in part interstratified with beds or stringers of pebbly sand or sandy gravel. The few available outcrops commonly show some black heavy-mineral cross lamination; however, crossbedding in the upper, exposed part of the unit is much less conspicuous than in the Omar barrier-sand lithofacies, which crops out in the central upland adjacent to the west of the Joynes Neck terrane.

\section{TYPE SECTION}

A borehole section on Joynes Neck in east-central Accomack County is here designated the type section of the Joynes Neck Sand (fig. 22). At this locality, the Joynes Neck Sand is $30 \mathrm{ft}(9 \mathrm{~m})$ thick and disconformably(?) overlies a 15 -ft-thick (4.5-m-thick) section of very fine, medium-gray shelly sand of the Accomack Member of the Omar Formation. 


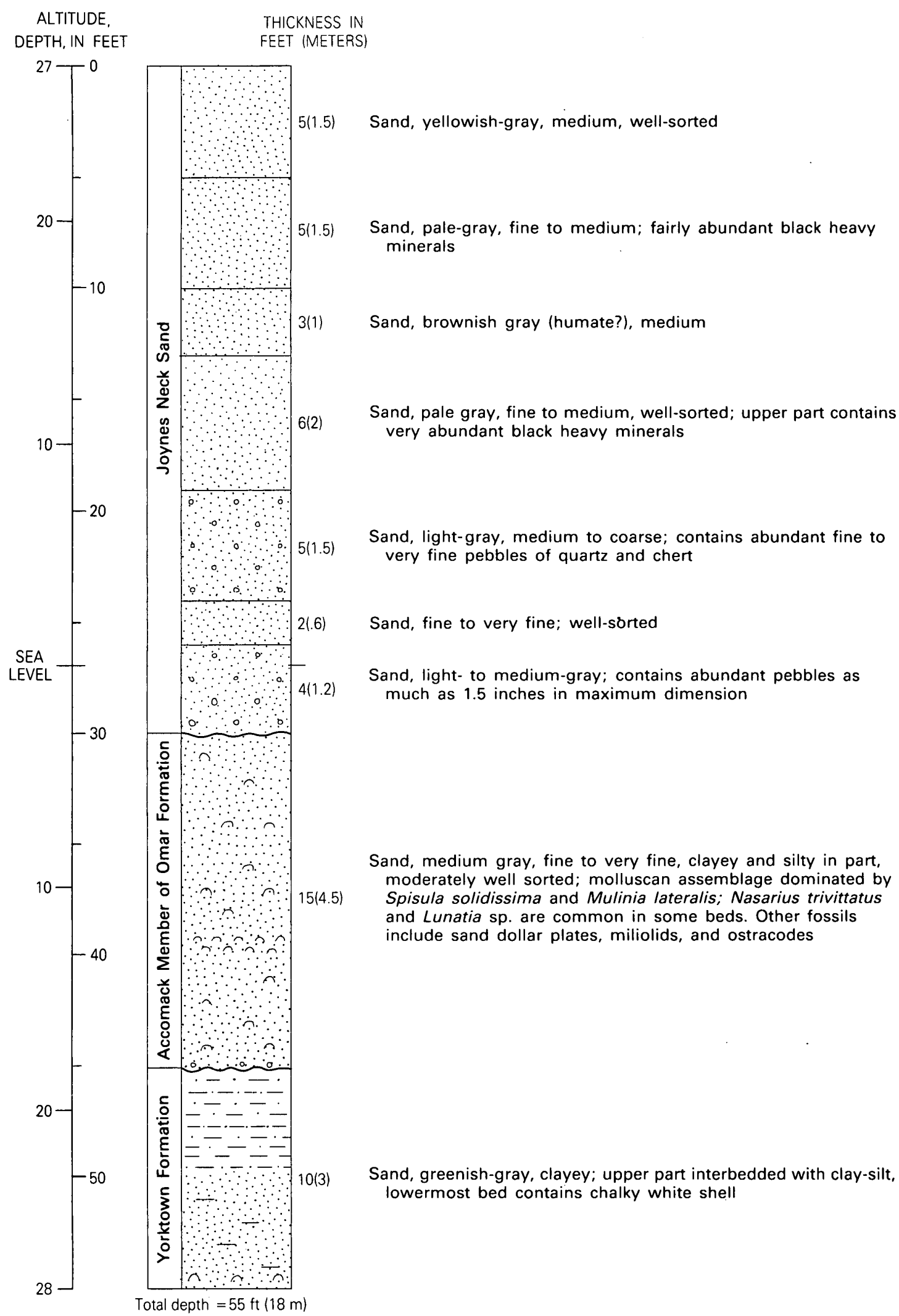

Figure 22.--Type section of Joynes Neck Sand at borehole locality A-15 in the Joynes Neck area of east-central Accomack County. The borehole site is on county road 652 about $1.5 \mathrm{mi}(2.4 \mathrm{~km})$ east-southeast of the town of Accomac and about $0.5 \mathrm{mi}(0.8 \mathrm{~km}$ ) southeast of the Edge Hill Cemetery (see pl. 2 and the Accomac 7.5-min quadrangle). 
The Joynes Neck type section is a fining-upward se quence that appears to represent a single marine transgression. The lower $11 \mathrm{ft}(3.3 \mathrm{~m})$ is largely medium to coarse sand containing abundant fine to coarse pebbles of quartz, chert, sandstone, and quartzite. The middle and upper parts of the section consist of fine to medium, well-sorted, pale-gray or yellowish-gray quartz sand. Black heavy minerals, mainly ilmenite and magnetite, constitute as much as 3 percent of the sand fraction.

STRATIGRAPHIC RELATIONSHIPS

The Joynes Neck Sand is thought to truncate the upper part of the Accomack Member of the Omar Formation along the Metomkin scarp and, east of the scarp, to disconformably overlie shelly fine sands of the lower part of the Accomack. Along its eastern margin of outcrop, the Joynes Neck is clearly truncated by deposits of the Holocene barrier-lagoon complex.

The relationship of the Joynes Neck in southern Northampton County to the Butlers Bluff Member of the Nassawadox Formation is very uncertain, and at least two interpretations are possible: (1) the Joynes Neck Sand and the Butlers Bluff Member represent near-shore and barrier-spit deposits, respectively, that are essentially equivalent in age or (2) the Joynes Neck beds truncate the barrier sands of the Butlers Bluff Member along the Kiptopeke scarp and, thus, are younger than the Butlers Bluff, at least in part. Whichever interpretation is correct, the Joynes Neck deposits occupy a stratigraphic and geomorphic position very similar to that of the Occohannock beds on the west side of the Delmarva Peninsula. Accordingly, the Joynes Neck and Occohannock beds may represent nearshore-shelf and bay-bottom deposits, respectively, that were deposited contemporaneously on opposite sides of an older "barrier" formed by the Butlers Bluff and Accomack sediment complexes.

The relationship of the Joynes Neck Sand to the younger(?) Wachapreague Formation, which is described in the following section, is not clear because of the lack of borehole data in the area of contact between the two units. It seems probable, however, that the fining-upward Joynes Neck sequence and the Wachapreague beds, which commonly coarsen upward, represent transgressive and regressive phases of a single major marine cycle. However, the break in topography between the Joynes Neck and Wachapreague terranes, marked by the Mappsburg scarp, indicates that a stillstand or minor fluctuation of sea level separated deposition of the two units. This sea-level fluctuation should correspond to the fluctuation that formed the Pungoteague scarp (pl. 1).
AGE AND CORRELATION

Because fossil flora and fauna have not been found in the Joynes Neck Sand, biostratigraphic and paleoclimatic comparisons with other Delmarva lithic units cannot be made. Relative age estimates for the Joynes Neck Sand must be based on regional stratigraphic and geomorphic relationships (see Mixon and others, 1982), especially its relationship to the Wachapreague Formation.

\section{WACHAPREAGUE FORMATION}

\section{DEFINITION}

The narrow coastal lowland of the Bell Neck sandridge complex, which extends from the southern tip of the Delmarva Peninsula northeastward to the vicinity of Metomkin Bay, is the lowest and, presumably, the youngest depositional surface of Pleistocene age on the Atlantic side of the peninsula. The lowland ranges in altitude from sea level, at its eastern border with the Holocene barrier-lagoon complex, to slightly more than $15 \mathrm{ft}(4.5 \mathrm{~m})$ at the toe of the east-facing scarps that form its western boundary; it attains a maximum width of about $2.5 \mathrm{mi}(4 \mathrm{~km})$ near Wachapreague.

The surface of the lowland differs from the older, higher Delmarva depositional surfaces to the west in that constructional coastal landforms, including beach ridges and cuspate spits, are remarkably well preserved (see figs. 23, 24). The sand, silt, and clay deposits that underlie the lowland are also distinctive because of floral and faunal assemblages indicating deposition, at least in part, during cool climatic conditions. These deposits, as much as $40 \mathrm{ft}(12 \mathrm{~m})$ in thickness, are typically developed in the Wachapreague, Va., area and are herein named the Wachapreague Formation.

LITHOLOGY AND TYPE SECTION

A borehole section on the crest of the relict Upshur Neck barrier ridge, $1 \mathrm{mi}(1.6 \mathrm{~km})$ north-northeast of the center of the town of Wachapreague, is here designated the type section of the Wachapreague Formation (fig. 23 , loc. $W-1)$. Here the Wachapreague is $37 \mathrm{ft}(11.3 \mathrm{~m})$ thick and unconformably overlies greenish-gray fine sand of the Yorktown Formation.

At the type section, the Wachapreague Formation is divisible into two distinct lithic units, which may represent mappable members (fig. 25). The lower unit, about $20 \mathrm{ft}(6 \mathrm{~m})$ thick, is composed of clayey and silty, fine to very fine gray sand and clay-silt. Although no macrofossils were found in the type section, equivalent beds at 


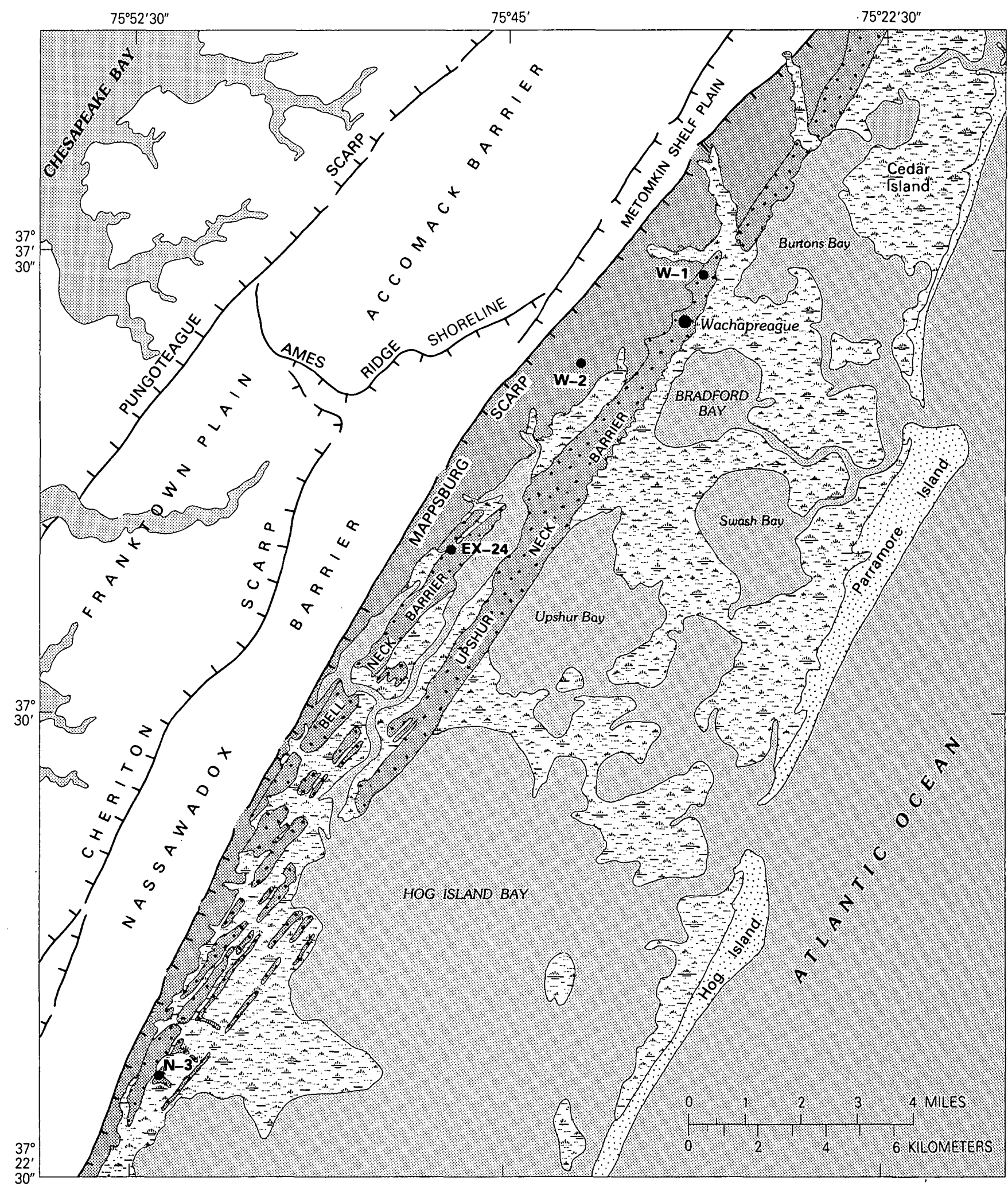

FIGURE 23.-Sketch map showing relationship of Bell Neck sand-ridge complex to present-day barrier islands and older geomorphic features of the southern Delmarva Peninsula. At least 11 individual ridges or sets of ridges, thought to represent a regressive sequence of small barriers and barrier spits, can be distinguished on aerial photographs of the area. Deposits at borehole localities W-1 (type section of Wachapreague Formation), W-2, Ex-24, and N-3 contain pollen, ostracode, and molluscan asemblages characterized by mixture of mildtemperate and cold-temperate climatic indicators. 


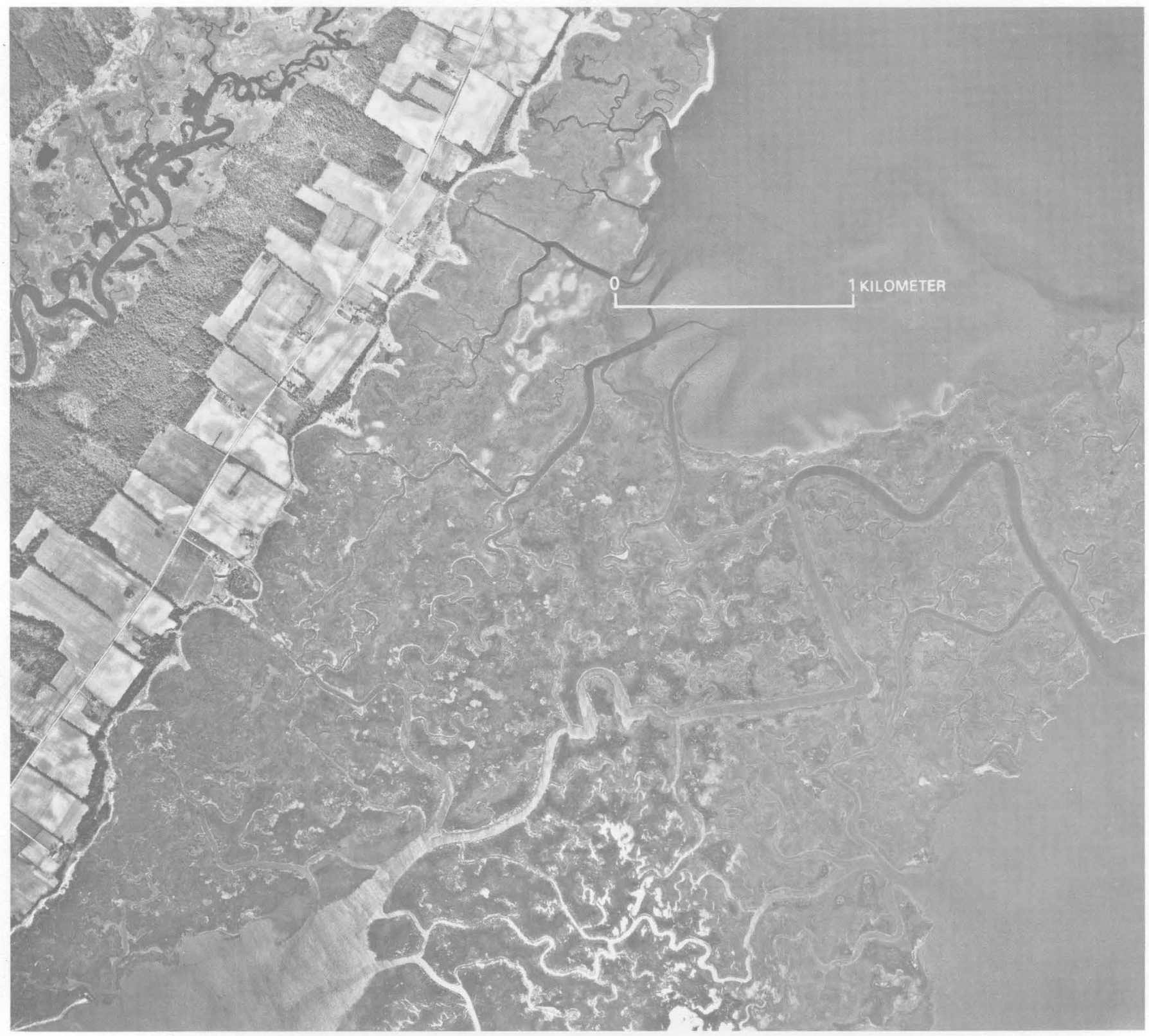

FiguRE 24.-Upshur Neck barrier ridge southwest of Wachapreague, Va. Crescentic forms on southeast side of the main sand ridge are believed to be relict cuspate spits.

nearby localities contain an abundant and fairly diverse molluscan assemblage that indicates deposition in shallow, nearshore-shelf waters. Pollen is also abundant and well preserved in the lower unit.

The upper lithic unit of the Wachapreague Formation, which is $17 \mathrm{ft}(5.2 \mathrm{~m})$ thick at the type section, consists of medium to very coarse gravelly sand. The pebbles are mainly black chert and quartz and are commonly 1 in or more in maximum dimension. No fossils have been obtained from these beds.
A natural exposure of the gravelly sand unit, southeast of Willis Wharf where the tidal waters of Parting Creek cut through the relict Bell Neck barrier ridge, provides a reference section for the upper part of the Wachapreague Formation. Here a 10-ft-high (3-m-high) exposure excavated into the creek bank and the narrow beach, which is exposed at low tide, exposes thin- to medium-bedded, yellowish-gray, gravelly sand, which is interbedded with finer, better sorted sand. Black heavymineral lamination in the well-sorted sand shows both 
fine cross-stratification and long, continuous, horizontal to gently inclined bedding suggestive of a beach or near-

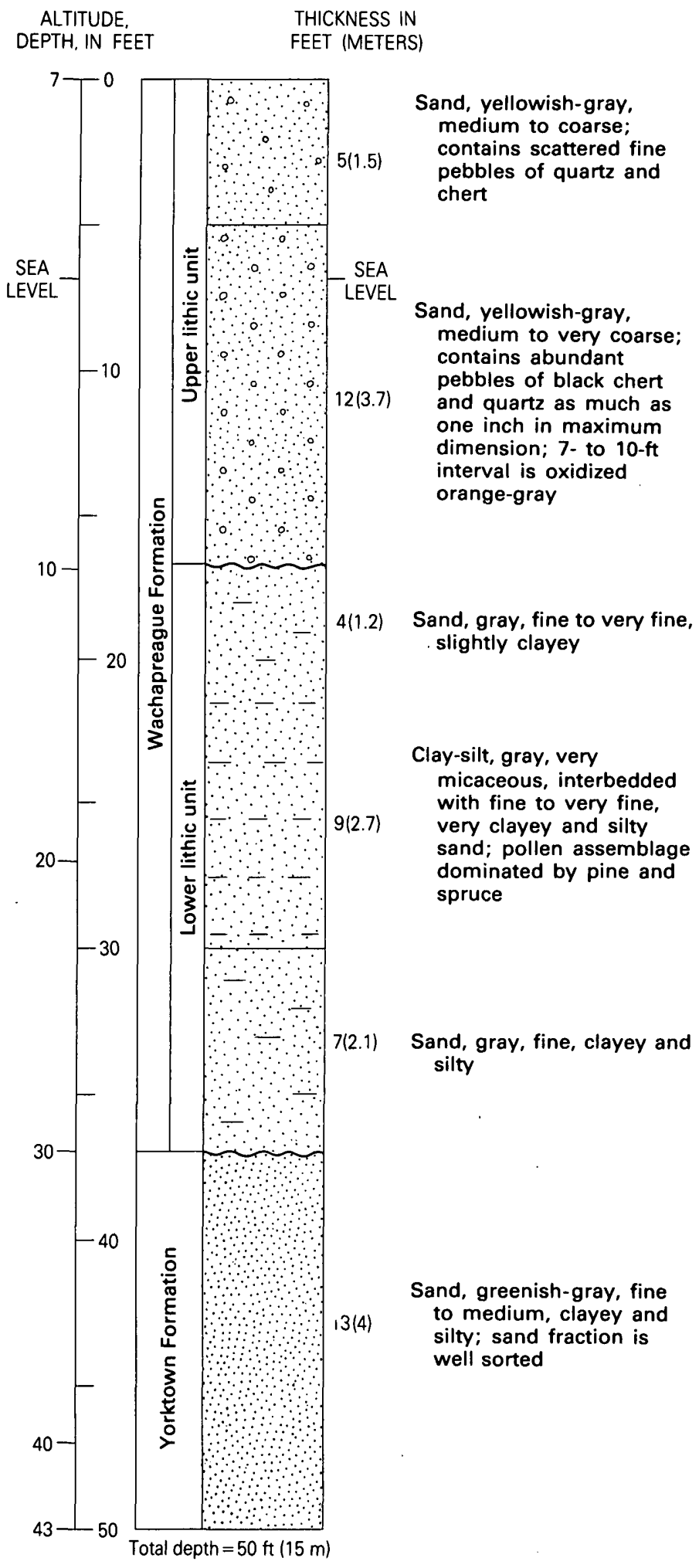

FIGURE 25.-Type section of Wachapreague Formation at borehole locality W-1 about $1 \mathrm{mi}(1.6 \mathrm{~km})$ north-northeast of the center of Wachapreague, Va. (See fig. 23 and pl. 2 for location.) beach depositional environment. The association of the gravelly sand unit with landforms interpreted as beach ridges and cuspate spits at this locality and at other sites in the Wachapreague, Exmore, and Nassawadox quadrangles (locs. W-1, Ex-24, and N-3) indicates that the gravelly sand unit is extensively distributed.

$$
\text { FAUNA }
$$

The clayey silts and clayey and silty sands of the lower and middle parts of the Wachapreague Formation contain pollen, ostracode, and molluscan assemblages that differ markedly from those found in the Omar and Nassawadox Formations. For example, the ostracode assemblages from shelly sands in the Exmore and Wachapreague quadrangle area (locs. W-2, Ex-24) contain a mix of species typical of mild-temperate climatic zones [Cytheridae n. sp., Cushmanidea seminuda (Cushman, 1906), Pseudocytheretta edwardsi (Cushman, 1906)] and cool- to cold-climate indicators such as Elofsonella concinna (Jones, 1856) and Muellerina canadensis (Brady, 1870). Today, along the Atlantic coast, Elofsonella concinna is not known to occur south of the Gulf of Maine and is considered to indicate cold-temperate to frigid climatic conditions (J. E. Hazel, written commun., 1971). Muellerina canadensis occurs in both the mild- and cold-temperate climatic zones of the Atlantic coast. The mixture of mild- and cold-temperate ostracode species suggests marine conditions typical of the northern part of the present-day mild-temperate climatic belt, which extends from Cape Cod, Mass., to Cape Hatteras, N.C. (J. E. Hazel and R. M. Forester, written commun., 1971, 1976).

The molluscan assemblage from the Bell Neck locality (Ex-24) includes Mesodesma arctatum and Siliqua costata, which today range from Greenland to Chesapeake Bay and from the Gulf of St. Lawrence to North Carolina, respectively (B. W. Blackwelder, written commun., 1979). Neither species is known to occur in the Omar and Nassawadox beds. In the Wachapreague Formation, the Mesodesma arctatum and Siliqua costata occur together with Chione cancellata, a species ranging today from North Carolina south to Florida. Thus, like the ostracode assemblage, the molluscan assemblage is characterized by a mixture of cold-temperate and mildto warm-temperate species.

\section{FLORA}

The pollen assemblages from the type section of the Wachapreague Formation (W-1), from the shelly beds at Piggen (W-2) and Bell Neck (Ex-24), and from equivalent nonshelly strata to the southwest in the 
Nassawadox and Townsend quadrangles $(\mathrm{N}-3, \mathrm{~T}-16)$ indicate a progressive change from warm-temperate climatic conditions in earliest Wachapreague time to cool- or cold-temperate conditions in middle and late Wachapreague time. Evidence for the climatic change is particularly well documented by pollen assemblages in samples from boreholes near Piggen (W-2), about $2 \mathrm{mi}$ $(3 \mathrm{~km})$ southwest of the town of Wachapreague, and near the mouth of Mill Creek (T-16) about $1.5 \mathrm{mi}$ $(2.4 \mathrm{~km})$ east of Cape Center, Va. (L.A. Sirkin, written commun., 1975; T. Ager, written commun., 1979). At Piggen the basal beds of the Wachapreague include pine, oak, hickory, bayberry, and minor amounts of spruce-suggesting a mixed evergreen-deciduous forest vegetation and a warm-temperate climate. The pollen assemblage from the lower Wachapreague beds at Mill Creek is similar but also includes some black gum and sweet gum and abundant hemlock. In contrast, assemblages from the middle and upper parts of the Wachapreague at Piggen and Mill Creek are dominated by pine, spruce, birch, alder, and grass pollen. Spruce constitutes as much as 22 percent of the arboreal pollen. Oak and hickory are sparse or absent. The pine pollen generally contains a large component of small pollen grains (as compared to the large grain size characterizing pine pollen from warm-temperate forests), which suggests derivation from a forest adapting to cold climatic conditions. In summary, the pollen assemblages confirm the existence of cool climatic conditions in middle and late Wachapreague time as indicated by the ostracode and molluscan faunas. However, as might be expected, the pollen studies suggest that temperatures of nearby land areas were more extreme (warmer and cooler in early and late Wachapreague time, respectively) than indicated by the marine faunas.

\section{STRATIGRAPHIC RELATIONSHIPS}

The Wachapreague beds appear to truncate the Butlers Bluff Member of the Nassawadox Formation along the central part of the Mappsburg scarp (see pl. 1). Commonly, in areas east of the scarp, the Wachapreague beds unconformably overlie the Yorktown Formation (locs. W-1, W-2, Ex-35, T-16). Locally, as in the vicinity of Webbs Island $(\mathrm{N}-3)$, the Wachapreague beds appear to overlie the Stumptown Member(?) of the Nassawadox Formation with little or no indication of an erosional unconformity. The exact nature of the relationship between the Wachapreague beds and the older units deposited in warm-temperature climatic conditions is very uncertain, however, and needs further study.

A truncating relationship between the Wachapreague Formation and the older Joynes Neck Sand is suggested by the apparent inset of both the depositional surface at the top of the Wachapreague and the surface of unconformity at the base of the unit below corresponding surfaces of the Joynes Neck Sand. Unfortunately, borehole data in the area of contact between the two units are not available. Thus, the relationship between the Wachapreague and the Joynes Neck remains speculative until additional data are available.

\section{Rel.ATIVE and AbSOlute AGE Estimates}

The Wachapreague Formation truncates and overlaps the Omar and Nassawadox Formations and, thus, is clearly younger than these units. The Wachapreague is considered to be younger than the Joynes Neck Sand on the basis of the stratigraphic and geomorphic relationships discussed in the previous section. The difference in age between the Wachapreague and the Joynes Neck is probably not great, however, as indicated by the following factors: (1) little, if any, differences in degree of dissection of the two units, (2) little or no apparent difference in soil development, (3) the absence of a prominent scarp separating the two units, and (4) the general parallelism of shoreline trends at the landward margin of the units.

Estimates of absolute age for the Wachapreague Formation have been obtained only from the upper shelly beds at Bell Neck (loc. Ex-24) that contain a spruce-rich pollen assemblage. Whole valves of Mulinia lateralis from the interval at $11-16 \mathrm{ft}(3.5-5 \mathrm{~m})$ below sea level yielded a radiocarbon age of $>33,000$ years B.P. (USGS radiocarbon lab no. W-2594), which demonstrates only that the shell material is too old to date reliably by the radiocarbon method. Mercenaria sp. from the same sample interval in the Bell Neck borehole yielded an estimated age of $128,000 \pm 1,000$ years B.P. based on the uranium-thorium and uranium-protactinium isotope dating methods (Mixon and others, 1982, table 2). An amino-acid-racemization age estimate of 82,000 years B.P., based on a D/L-leucine ratio of 0.284 obtained from whole valves of Mesodesma arctatum, has also been reported from these same beds (Belknap, 1979). The uranium-isotope and amino-acid-racemization age estimates are somewhat conflicting but, even if considered to be only approximately correct, would suggest a Sangamon to early Wisconsin age for the Wachapreague Formation.

\section{CORRELATION}

The Wachapreague is similar in stratigraphic position and geomorphic setting to a sequence of barrier sand and lagoonal mud in the outermost Coastal Plain area 
south of Chesapeake Bay and east and southeast of Norfolk, Va., that is included in the upper member of the Sand Bridge Formation of Oaks and Coch (1973, pl. 2, facies 3 , in part, and facies 4 of the upper member of the Sand Bridge). This upper part of the Sand Bridge lies east of the Hickory scarp and includes the deposits underlying the "Sand-ridge and Mud-flat complex" of Oaks and Coch $(1973$, p. 22). The sand ridges and mud flats of this geomorphic unit are considered by Oaks and Coch to represent a relict barrier-lagoon complex of latest Pleistocene age (Oaks and Coch, 1973, p. 95-97). Thus, the upper surfaces of both the Wachapreague and the Sand Bridge are characterized by linear ridges and swales; the surface of each unit is interpreted as a progradational sequence of barriers and narrow lagoons. Similarly, the coastal lowlands underlain by the Wachapreague beds and the barrier sand deposits of the Sand Bridge are bounded on the west by east-facing scarps that have approximately the same toe elevations [10-17 ft (3-5.2 m)]. Therefore, the similarities in lithology, stratigraphic position, and geomorphic expression, in conjunction with similar altitudes of capping depositional surfaces and bounding scarps, provide a basis for correlation of the Wachapreague Formation with the Sand Bridge deposits that lie east of the Hickory scarp.

For the above reasons, the Wachapreague strata would also appear to be correlative, at least in part, with marginal-marine beds in the outermost Coastal Plain of southern Delaware and Maryland that have been designated the Sinepuxent Formation (Owens and Denny, 1979b). Lithically, the Sinepuxent beds are similar to the lower silty and clayey fine sand member of the Wachapreague Formation. The Sinepuxent also contains cool-temperate faunal and floral elements such as Elofsonella concinna and spruce-rich pollen assemblages. However, the Sinepuxent has been considered to be of middle or late Wisconsin age on the basis of radiocarbon ages on peat from near the top of the unit (Owens and Denny, 1979b, p. A23). These ages led Owens and Denny to state that the Sinepuxent represents a major transgressive event in mid-Wisconsin time. In contrast, both the uranium-thorium and aminoacid-racemization age estimates obtained from the coarsening-upward Wachapreague sequence suggest deposition during a regression in latest Sangamon and (or) earliest Wisconsin time.

\section{HOLOCENE DEPOSITS}

Deposits of Holocene age constitute an appreciable volume of the southern Delmarva sediment complex in two main areas: (1) the modern barrier island and lagoon system, which borders the ocean side of the peninsula, and (2) the parts of the Chesapeake Bay and bay entrance that were deeply eroded during the last glacial maximum and subsequently partly filled during the Holocene rise in sea level. In addition, relatively thin but widely distributed estuarine and marsh deposits mantle the very shallow, shelflike bay area that appears to be a submerged extension of the broad baywardsloping Onancock lowland bordering the western side of the peninsula in Virginia.

\section{BARRIER-LAGOON COMPLEX}

Virginia has more than $80 \mathrm{mi}(130 \mathrm{~km})$ of Atlantic Ocean shoreline including 14 barrier islands, which range in width from less than $0.25 \mathrm{mi}(0.4 \mathrm{~km})$ to about $2 \mathrm{mi}(3 \mathrm{~km})$, and an extensive coastal lagoon as much as $8 \mathrm{mi}(13 \mathrm{~km})$ in width. The unconsolidated sand, silt, clay, and peat of Holocene age that underlie the barrierlagoon system thicken eastward from a feather edge along the mainland side of the lagoon to as much as $36 \mathrm{ft}(11 \mathrm{~m})$ to the east of Wachapreague and $50 \mathrm{ft}(15 \mathrm{~m})$ or more near the southern end of Assateague Island (borehole loc. CE-2). In a study of the Holocene deposits of the Wachapreague Inlet and Metomkin Bay areas, S. Harrison (1972) divided the Holocene barrier-lagoon environment into several subenvironments including offshore, barrier inlets, tidal channels, bays, tidal flats, salt marshes, and barrier-island sand ridges. Harrison also described the biota, sediment types, and sedimentary structures that characterize each subenvironment and the biologic processes that influence sedimentation in the area. The three-dimensional distribution of the lagoonal deposits in the Wachapreague area and the age and submergence histories of these deposits have been described by Newman and Munsart (1968) and Newman and Rusnak (1965).

\section{DEPOSITS OF THE CHESAPEAKE BAY MOUTH}

The unconsolidated deposits of latest Pleistocene and Holocene age in the lowermost Chesapeake Bay area and the bay entrance have been studied by W. Harrison and others (1965) and Meisburger (1972). These workers used data obtained from marine seismic reflection surveys and boreholes drilled for engineering tests for the Chesapeake Bay Bridge-Tunnel to map the configuration of the erosion surface at the top of the Tertiary section and to determine the shapes and trends of buried Pleistocene river channels. The character and sequence of lithic units composing the uppermost Pleistocene and Holocene sediment fill in the mouth of the modern Chesapeake Bay are remarkably similar to the older sedimentary sequence filling the Eastville paleovalley (see Meisburger, 1972, fig. 4; this report, fig. 18). 


\section{SUMMARY AND DISCUSSION OF LATE QUATERNARY GEOLOGIC HISTORY}

\section{DEVELOPMENT OF POST-YORKTOWN EROSION SURFACE}

Regional uplift and emergence of the Coastal Plain in the middle(?) and late Pliocene initiated development of the erosional unconformity that marks the top of the Tertiary section in the Delmarva Peninsula and Chesapeake Bay areas. However, the surface of unconformity as mapped today (fig. 9) is the cumulative result of many episodes of erosion in Pliocene, Pleistocene, and Holocene time and, in a traverse across the study area, varies considerably in age. For example, in the central upland area of Accomack County, the erosion surface on the Tertiary beds is overlain by the Accomack Member of the Omar Formation and, thus, is of pre-Accomack and early Accomack age (see Mixon and others, 1982). To the west in the Onancock lowland area (pl. 1), where the Kent Island-Nassawadox sequence locally overlies the Tertiary beds, the erosion surface was probably modified by estuarine erosional processes active during the high stand of the sea associated with the Sangamon interglaciation. Still farther west, the narrow paleochannels in Chesapeake Bay and in Tangier and Pocomoke Sounds (fig. 9) were cut deeply into the upper Tertiary strata, apparently by fluvial erosion during the low stand of the sea associated with the last glacial maximum 20,000-18,000 years ago (Hack, 1975). Subsequently, as a result of the Holocene rise in sea level, the channels have been partly filled by fluvial and estuarine sediments. One of the few known occurrences of present-day erosion of the upper Tertiary beds is in the deeper part of the Wachapreague Inlet channel east of Wachapreague, Va. At this locality, tidal currents are sufficiently strong to erode through the thin Quaternary cover into semiconsolidated clay-silts of the Yorktown Formation(?) (J. DeAlteris, oral commun., 1976).

In a very general way, the configuration of the erosion surface on the Tertiary beds is similar to that of the present-day topography underlain by Pleistocene and Holocene deposits. Thus, in the southern peninsula area, an erosional remnant of Tertiary strata extends as a buried ridge from near the mouth of Chesapeake Bay northeastward into southern Maryland where it merges with a broader, shallower Tertiary high (fig. 9). The position and shape of the Tertiary ridge is due in part to the excavation of the extensive lowland west of the peninsula, which is presently occupied by the Chesapeake Bay estuary, and in part to erosion of the eastern peninsula area by successive marine transgressions.

In Virginia, contours on the surface of the Tertiary beds delineate three cross-peninsula paleodrainages superimposed on the northeast trend of the buried Tertiary ridge (fig. 9). The two paleochannels in the southern and northern parts of Accomack County may be former drainageways of the Nanticoke and Pocomoke Rivers, respectively. The paleochannel in central and southern Northampton County is much larger and is believed to be a former drainageway of the Susquehanna-Potomac river system. Filling of the paleochannels and southward diversion of the drainageways probably resulted from southward progradation of the Accomack and Nassawadox barrier spits.

\section{PROGRADATION OF THE ACCOMACK BARRIER SPIT}

During the rise in sea level associated with deposition of the Accomack Member of the Omar Formation, the lowland occupied by the drainages of the Susquehanna and Potomac Rivers and their tributaries was flooded, creating an embayed area larger than the present Chesapeake Bay. Uranium-series age estimates from fossil coral (Mixon and others, 1982) suggest that this major transgressive event is correlative with oxygenisotope stage 7 (Emiliani, 1972; Fairbanks and Matthews, 1978). In the area of the present-day southern Delmarva Peninsula, the transgressing sea partially beveled older erosion surfaces on the Yorktown Formation and, west of the Chesapeake Bay, notched the Yorktown and younger beds along the Suffolk and Harpersville scarps (Mixon and others, 1982, pl. 1). As the seas approached and exceeded present sea level, a barrier-spit and barrier-island complex was constructed partly across the wide reentrant in the coastline formed by the embayment of the Susquehanna-Potomac lowland (fig. 26A). In the early stages of transgression, topographic highs on the old Yorktown erosion surface in northern Accomack County, Va., and southern Worcester County, Md., may have formed a headland that anchored or "buttressed" the barrier spit near its northern end (fig. 9). During the late stages of transgression, submergence and burial of the Tertiary "highs" forming the headland resulted from the continued rise in sea level and westward and southward movement of the coastal barrier system. At maximum transgression the reentrant in the coastline extended from the Walston Silt-Beaverdam Sand terrane in northern Worcester County, Md. (Owens and Denny, 1978, 1979a,b), southwestward to highlands near Yorktown and Norfolk, Va. At the same time, the ancestral Chesapeake estuary extended northwestward to the Fall Line near the inner edge of the Virginia-Maryland Coastal Plain. The maximum extent of the Accomack barrier spit is unknown, but the relict Ames Ridge 


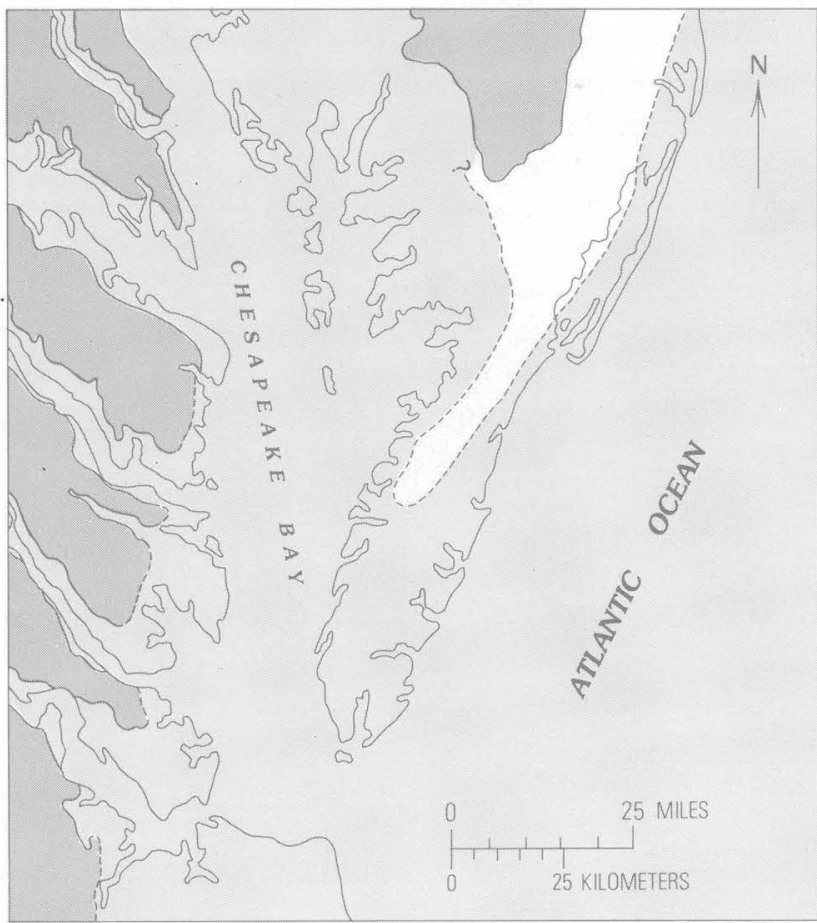

A

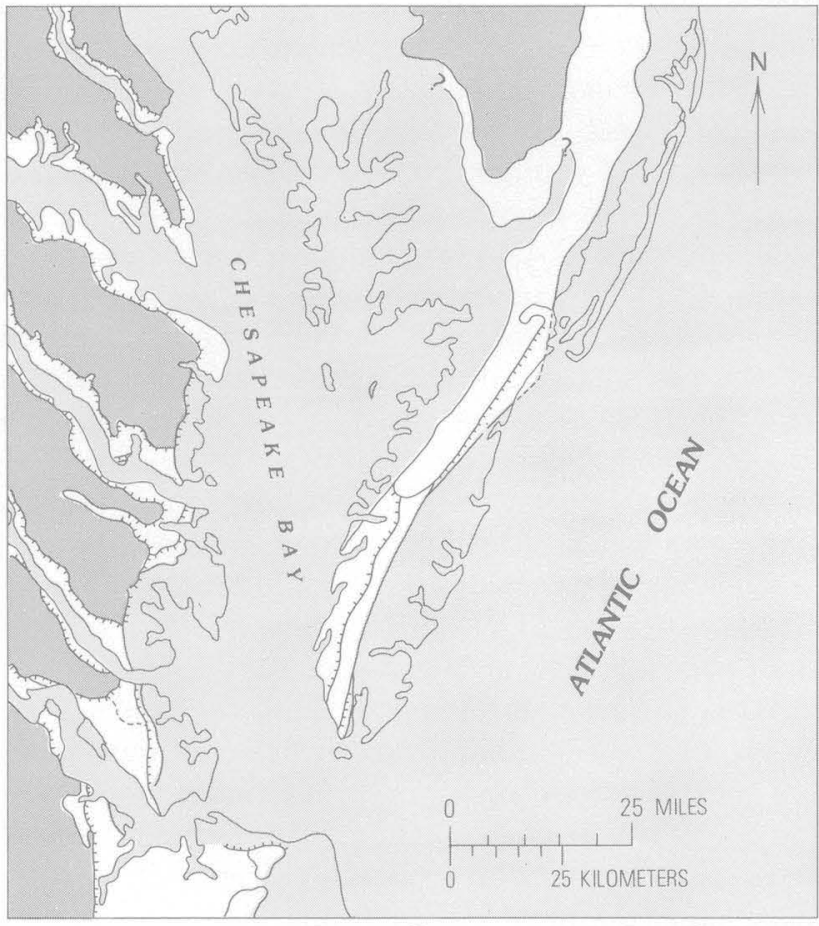

C
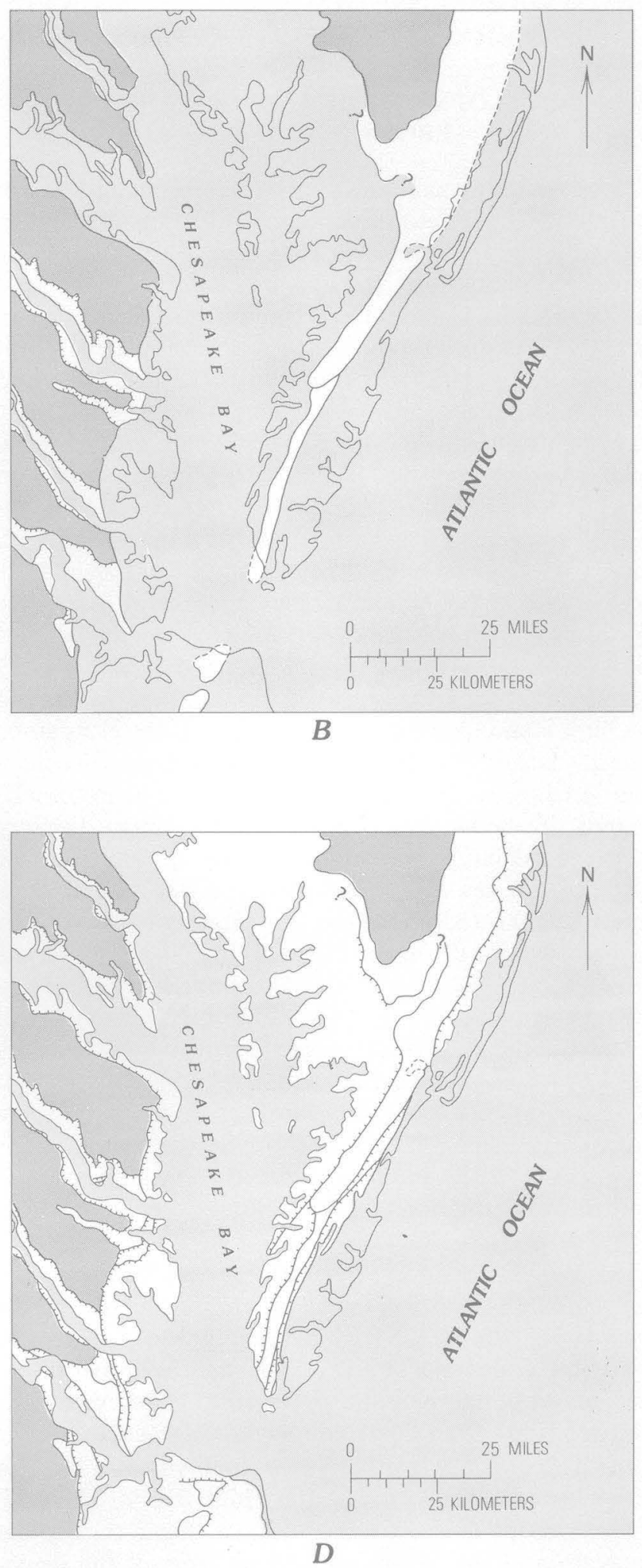

FIGURE 26.-Paleogeography of the southern Delmarva Peninsula and adjacent areas in late Quaternary time. $A$, Development of the Accomack barrier-spit complex, relative maximum sea level 40-50 ft (12-15 m) higher than present; $B$, southward progradation of the Nassawadox barrier spit, relative sea level at +30 to $+25 \mathrm{ft}(+9$ to $+7.5 \mathrm{~m}) ; C$, deposition of the Kent Island and Wachapreague Formations, relative maximum sea level at +15 to $+20 \mathrm{ft}(+4.5$ to $+6 \mathrm{~m}) ; D$, emplacement of the Holocene barrier-lagoon complex, relative maximum sea level at or slightly higher than present. 
shoreline in southern Accomack County (see pl. 1) may approximate the southern edge of the subaerial part of the barrier.

\section{DEPOSITION OF THE NASSAWADOX BARRIER-SPIT COMPLEX}

The Nassawadox beds include the fluvial, estuarine, nearshore-shelf, barrier, and backbarrier deposits of late Pleistocene age that underlie the mainland part of the Delmarva Peninsula in the area south of the relict Ames Ridge shoreline (pl. 1). The Nassawadox is similar lithically to the Accomack barrier complex adjacent to the north but is tentatively interpreted to have been emplaced during a high stand of the sea that was separate from and later than the high stand associated with deposition of the Accomack beds (Mixon and others, 1982; this report, fig. 26B). The principal bases for differentiating the two sequences include (1) the smaller size and slightly divergent trend of the Nassawadox barrier, (2) the somewhat lower altitudes of depositional surfaces associated with the Nassawadox beds, and (3) considerably younger uranium-thorium and amino-acidracemization age estimates obtained from shell material in the Nassawadox beds as compared with those from the Accomack. However, the usefulness of the age determinations is diminished by overlapping and conflicting age estimates, at least in part, for the two barrier complexes (Mixon and others, 1982; Belknap, 1979).

To be balanced against the geomorphic data and the uranium-thorium and amino-acid-racemization age estimates are factors that suggest little or no difference in age between the Nassawadox and Accomack barrier complexes. For example, preliminary investigations of soils in the Delmarva area by M. Pavich and H. Markewich of the USGS have shown no appreciable differences in soil development on the Accomack and Nassawadox barrier surfaces (Pavich and Markewich, oral commun., 1982). The similarity in soils suggests either that there is little difference in age between the barrier surfaces or that the soils are approaching equilibrium.

Of potentially greater significance than the maturity of soils on the barrier surfaces are the similar altitudes of the main Accomack and Nassawadox shell beds. These shell beds, which were deposited in nearshoreshelf to open-bay environments, are presumed to record the main transgressive phase of the Accomack and Nassawadox sediment complexes. Unfortunately, borehole data are very sparse in the area of contact between the Accomack and the Nassawadox (pl. 2, see the Nassawadox, Exmore, and Accomac quadrangle areas), and additional data along one or more north-south cross sections across the relict Ames Ridge shoreline are needed in order to fully understand the stratigraphic relationships.

As a result of the stratigraphic uncertainties regarding the Nassawadox, two alternative depositional sequences are proposed for the Accomack and Nassawadox. The preferred interpretation is as follows: (1) emplacement of the transgressive and regressive phases of the Accomack barrier-backbarrier complex and associated nearshore-shelf deposits, (2) withdrawal of marine waters from the ancestral Chesapeake estuary, incision of the Eastville paleovalley, and extensive erosion of the Accomack and equivalent strata in the lower Chesapeake area, (3) a rise in sea level to an altitude of about $+35 \mathrm{ft}(+10.5 \mathrm{~m})$ relative to present sea level, concurrent filling of the Eastville paleochannel with fluvial and estuarine-marine deposits (the Stumptown), and emplacement of the Nassawadox barrier spit and associated shallow-water backbarrier and nearshore-shelf deposits (the Butlers Bluff and Occohannock beds and, possibly, the Joynes Neck Sand). The deposition of the Joynes Neck beds and at least the upper part of the Occohannock may have been separated in time from the formation of the Nassawadox spit by a minor fluctuation of sea level.

Alternatively, if detailed subsurface mapping in the central part of the study area should show equivalency of the Nassawadox and Accomack shell beds, the order of deposition of map units would be revised as follows: (1) filling of the Eastville paleochannel and other lows on the post-Yorktown erosion surface with fluvial and estuarine-marine deposits (Stumptown beds), (2) deposition of shelly nearshore-shelf sands in the Northampton and southeastern Accomack County areas and progradation of the Accomack barrier-spit complex southwestward over the nearshore-shelf deposits, (3) a minor regression or fluctuation of sea level and emplacement of the Nassawadox spit complex (the main part of the Butlers Bluff and Occohannock beds). This interpretation differs from the first mainly in the timing of deposition of the Stumptown and in the duration and extent of the regression that occurred after emplacement of the Accomack barrier spit.

\section{DEPOSITION OF THE KENT ISLAND SEDIMENTS}

The Kent Island sediments, consisting mainly of sandy and gravelly deposits of estuarine origin, underlie the broad, bayward-sloping lowland that borders the western side of the Delmarva Peninsula. The emplacement of these deposits was contemporaneous, at least in part, with the cutting of the low but conspicuous westfacing scarps that separate the lowland from the central Delmarva upland, adjacent to the east (pl. 1; fig. 26C). 
The nature of the Kent Island in Virginia and its geomorphic setting strongly suggest that the unit represents the sandy bottom deposits of an ancestral Chesapeake Bay.

Although the lithology and distribution of the Kent Island are fairly well known, the time of deposition of the unit and the relationship of the beds in Virginia to the type Kent Island in central Maryland are not entirely clear, in part because of the differing radiocarbon ages and paleoclimatic data obtained from the two areas. The differences in data and in interpretation are probably due partly to marked differences in the environments of deposition in the Virginia (lower estuarine) and Maryland (upper estuarine) areas and partly to the more complete and more abundantly fossiliferous upper Pleistocene stratigraphic section available in Virginia.

As discussed previously, considerable variation in Kent Island lithology and relationships exist within the study area. For example, in northern Accomack County, the fine to coarse, generally poorly sorted Kent Island sediments unconformably overlie older Pleistocene beds of the Accomack barrier complex or Tertiary strata of the Eastover and Yorktown Formations. Thus, the rock units and stratigraphic relationships in this area are similar to those in the Kent Island terrane of southern Maryland. However, farther south in Accomack County, in the area to the southwest of prominent erosional highs on the Tertiary beds (fig. 9), the Kent Island sediments become finer grained and better sorted and grade downward without a perceptible break into shelly sands that are equivalent to shell beds encountered by boreholes in the Occohannock and Butlers Bluff terranes of Northampton County. These relationships are extremely important because they closely tie the Kent Island to the warm-climate Nassawadox sequence. The tie to the Nassawadox explains the warm-temperate pollen assemblages and the peats too old to date by the radiocarbon method that were obtained from the Kent Island beds in Accomack County, Va., and southern Somerset County, Md. (see discussion of paleoclimate and age of the Kent Island Formation).

\section{MARGINAL-MARINE DEPOSITS OF LATE PLEISTOCENE AGE BORDERING THE EASTERN SIDE OF THE DELMARVA UPLAND}

Surficial Pleistocene deposits bordering the eastern side of the Delmarva upland include two main depositional sequences, the Joynes Neck Sand and the Wachapreague Formation. The fining-upward gravelly sand of the Joynes Neck is interpreted herein to be a transgressive nearshore-shelf deposit emplaced during a high stand of the sea associated with the Sangamon in- terglaciation (fig. 26B). As the Joynes Neck sediments are unfossiliferous, their deposition during a warm climate is an inference based mainly on their correlation with interglacial deposits of the Norfolk, Va., area (the Norfolk Formation and Kempsville Formation of Oaks and Coch; see Oaks and Coch, 1973, and Valentine, 1971). In contrast to the Joynes Neck, the coarseningupward silty to gravelly sand of the Wachapreague, the change from warm- to cool-temperate climatic conditions during deposition, the seaward decrease in altitude of the Wachapreague depositional surface, and the age estimates obtained for the shelly lower and middle parts of the unit collectively suggest that the Wachapreague was deposited during the final regression of the sea at the end of the Sangamon interglaciation (fig. 26C). If this interpretation is correct, the Mappsburg scarp represents a stillstand or minor fluctuation of sea level rather than a major transgressive event.

The temporal relationship of the Wachapreague beds and the lithically similar Sinepuxent Formation of Maryland and Delaware remains a problem. As discussed above, the Wachapreague is believed to be a dominantly regressive nearshore-marine sequence deposited in late Sangamon(?) and early Wisconsin time. In contrast, the Sinepuxent is thought to record a major transgressive event in the middle Wisconsin (Owens and Denny, 1979b, p. A22-A23). The differences in interpretation of these seemingly correlative rock units are due in large part to the conflicting age estimates, which include uranium-thorium isotope, amino-acid-racemization, and radiocarbon ages on shell material from the Wachapreague beds and radiocarbon ages on peat and shells from the Sinepuxent. As part.of additional work on the ages of these units and their relationship to paleo-sea level, it is important to determine the depositional environment of the dated peats from the upper Sinepuxent beds (see Owens and Denny, $1979 \mathrm{~b}$, p. A23). Were the dateable peat beds deposited in a backbarrier environment at or near sea level or in freshwater ponds or shallow lakes on an emergent shelf at some time after withdrawal of the sea?

Of potentially great importance to a resolution of the Wachapreague-Sinepuxent problem and to determination of sea level in middle Wisconsin time is an ongoing study of a thin, surficial barrier-backbarrier sequence in the vicinity of Mockhorn Island (pl. 1), a low sand ridge about halfway between the mainland part of the southernmost Delmarva Peninsula and the present-day barrier islands (K. Finkelstein, U.S. Army Corps of Engineers, oral commun., 1982). A preliminary radiocarbon age from peaty sand at the base of the unit suggests that the deposists may be of middle Wisconsin age. The distribution of the deposits in the area between Mock- 
horn Island and the mainland and the shallow depths to the base of the unit suggest that it overlies the Wachapreague and, therefore, is younger. More detailed studies to bracket the age of the Mockhorn Island barrier-backbarrier sequence and to determine the nature of its contact (conformable or unconformable?) with the Wachapreague should greatly help in reconstructing the late Quaternary geologic history of the area.

\section{PALUDAL AND EOLIAN DEPOSITS OF LATE WISCONSIN AGE}

The lowering of sea level that accompanied the late Wisconsin glacial maximum exposed large areas of the formerly submerged Chesapeake Bay lowland to subaerial erosional and depositional processes. At this time the valleys of the James and Susquehanna Rivers in the lower bay area were eroded to depths of $155 \mathrm{ft}(47 \mathrm{~m})$ and $160 \mathrm{ft}(49 \mathrm{~m})$, respectively, below present mean low water (W. Harrison and others, 1965). Sediments deposited during the time of lowered sea level are best known in the vicinity of the present Chesapeake Bay entrance south of the study area. Here boreholes for the Chesapeake Bay Bridge-Tunnel penetrated peat at depths of about $90 \mathrm{ft}(27 \mathrm{~m})$ below sea level that yielded a radiocarbon age of 15,280 years B.P. and a coldtemperate pollen assemblage dominated by spruce, pine, birch, and alder (W. Harrison and others, 1965, p. 220, fig. 12).

Deposits of possible late Wisconsin age within the present study area include the fairly extensive fields of low sand dunes on the Franktown plain (pl. 1). These dunes are best developed in the areas to the east and south of Nassawadox and Hungars Creeks. The sandy bottom deposits of these tidal creeks, which were exposed to wind erosion during late Wisconsin glacioeustatic lowering of sea level, may have been a principal source of the dune deposits. The sandy ridge and runnel deposits of the lower Pocomoke River meander belt (pl. 1) may also be of late Wisconsin age, at least in part. Both the sand-dune and the fluvial ridge and runnel deposits may be equivalent in part to the Parsonsburg Sand of the central Delmarva Peninsula (Denny and others, 1979).

\section{HOLOCENE TRANSGRESSIVE DEPOSITS}

Overlying the cold-climate peats associated with the buried late Wisconsin erosion surface at the Chesapeake Bay entrance are younger peats, fine sand, and silty clay that contain pollen assemblages indicating deposition during warming climatic conditions (W. Harrison and others, 1965, figs. 11, 12; Meisburger, 1972, p. 33-36). Peat and oyster shell from the lower part of this section yield early Holocene radiocarbon ages ranging from about $11,590 \pm 150$ to $8,135 \pm 160$ years B.P. In general, the borehole and seismic reflection data obtained by these workers indicate filling of the Wisconsin Susquehanna paleovalley with a transgressive sequence that consists, from bottom to top, of gravel, peat, claysilt, and muddy sand of fluvial and estuarine origin. These deposits are very similar to the Pleistocene sediment fill of the Eastville paleovalley (fig. 18).

Basal peats from the lagoonal deposits east of Wachapreague, Va., collected at depths of 9-20 ft $(2.86-6 \mathrm{~m})$ below mean sea level, yield radiocarbon ages ranging from $2,550 \pm 70$ to $5,120 \pm 145$ years B.P., respectively (Newman and Rusnak, 1968). These late Holocene ages provide a minimum age for the Holocene barrier-lagoon complex in the southern Delmarva area.

\section{REFERENCES CITED}

Akers, W. H., 1972, Planktonic Foraminifera and biostratigraphy of some Neogene formations, northern Florida and Atlantic Coastal Plain: Tulane Studies in Geology and Paleontology, v. 9, no. 1-4, $139 \mathrm{p}$.

Belknap, D. F., 1979, Application of amino acid geochronology to stratigraphy of late Cenozoic marine units of the Atlantic Coastal Plain: Newark, Del., University of Delaware, Ph.D. dissertation, $567 \mathrm{p}$.

Blackwelder, B. W., and Ward, L. W., 1976, Stratigraphy of the Chesapeake Group of Maryland and Virginia, Geological Society of America Northeast-Southeast Sections, Joint Meeting 1976, Arlington, Virginia, Guidebook for Field Trip 7b: [Boulder, Colo., Geological Society of America], 55 p.

Bridges, P. H., 1976, Lower Silurian transgressive barrier islands, southwest Wales: Sedimentology, v. 23, p. 347-362.

Brown, P. M., Miller, J. A., and Swain, F. M., 1972, Structural and stratigraphic framework, and spatial distribution of permeability of the Atlantic Coastal Plain, North Carolina to New York: U.S. Geological Survey Professional Paper 796, 79 p.

Clifton, H. E., 1969, Beach lamination, nature and origin: Marine Geology, v. 7, no. 6, p. 553-559. 1981, Progradational sequences in Miocene shoreline deposits, southeastern Caliente Range, California: Journal of Sedimentary Petrology, v. 51, no. 1, p. 165-184.

Clifton, H. E., Hunter, R. E., and Phillips, R. L., 1971, Depositional structures and processes in the non-barred high-energy nearshore: Journal of Sedimentary Petrology, v. 41, no. 3, p. 651-670.

Colquhoun, D. J., 1969, Geomorphology of the lower coastal plain of South Carolina: South Carolina Division of Geology, MS-15, p. 1-36.

Cushing, E. M., Kantrowitz, I. H., and Taylor, K. R., 1973, Water resources of the Delmarva Peninsula: U.S. Geological Survey Professional Paper 822, $58 \mathrm{p}$.

Demarest, J. M., Biggs, R. B., and Kraft, J. C., 1981, Timestratigraphic aspects of a formation: Interpretation of surficial Pleistocene deposits by analogy with Holocene paralic deposits, southeastern Delaware: Geology, v. 9, no. 8, p. 360-365. 
Denny, C. S., and Owens, J. P., 1979, Sand dunes on the central Delmarva Peninsula, Maryland and Delaware: U.S. Geological Survey Professional Paper 1067-C, 15 p.

Denny, C. S., Owens, J. P., Sirkin, L. A., and Rubin, Meyer, 1979, The Parsonsburg Sand in the central Delmarva Peninsula, Maryland and Delaware: U.S. Geological Survey Professional Paper 1067-B, 16 p.

Emiliani, Cesare, 1972, Quaternary paleotemperatures and the duration of the high-temperature intervals: Science, v. 178, no. 4059, p. $398-401$.

Fairbanks, R. G., and Matthews, R. K., 1978, The marine oxygen isotope record in Pleistocene coral, Barbados, West Indies: Quaternary Research, v. 10, no. 2, p. 181-196.

Hack, J. T., 1957, Submerged river system of Chesapeake Bay: Geological Society of America Bulletin, v. 68, no. 7, p. 817-830.

Hansen, H. J., III, 1966, Pleistocene stratigraphy of the Salisbury area, Maryland, and its relationship to the lower Eastern Shore-A subsurface approach: Maryland Geological Survey Report of Investigations $2,56 \mathrm{p}$.

1967, Hydrogeologic data fron the Janes Island State Park test well (1,514 feet) Somerset County, Maryland: Maryland Geological Survey Basic Data Report 3, 24 p.

Harrison, S. C., 1972, The sediments and sedimentary processes of the Holocene tidal flat complex, Delmarva Peninsula, Virginia-U.S. Office Naval Research, Geography Programs, Project NR 388 022, Technical Report: Louisiana State University Coastal Studies Institute Technical Report 112,107 p.

Harrison, W., Malloy, R. J., Rusnak, G. A. and Terasmae, J., 1965, Possible late Pleistocene uplift, Chesapeake Bay entrance: Journal of Geology, v. 73, no. 2, p. 201-229.

Hazel, J. E., 1971a, Ostracode biostratigraphy of the Yorktown Formation (upper Miocene and lower Pliocene) of Virginia and North Carolina: U.S. Geological Survey Professional Paper 704, 13 p.

1971b, Paleoclimatology of the Yorktown Formation (upper Miocene and lower Pliocene) of Virginia and North Carolina: Centre de Recherches de Pau Bulletin, v. 5 (suppl.), p. 361-375.

Hess, Melodie, 1977, Drill-hole logs and location map of surface and shallow subsurface materials, central and southern Delmarva Peninsula, Maryland, Delaware, and Virginia: U.S. Geological Survey Miscellaneous Field Studies Map MF-899, 2 sheets, scale $1: 250,000$.

Hobday, D .K., and Orme, A. R., 1975, The Port Durnford Formation: a major Pleistocene barrier-lagoon complex along the Zululand coast: Geological Society of South Africa Transactions, v. 77, p. 141-149

Hunter, R. E., Clifton, H. E., and Phillips, R. L., 1979, Depositional processes, sedimentary structures, and predicted vertical sequences in barred nearshore systems, southern Oregon coast: Journal of Sedimentary Petrology, v. 49, no. 3, p. 711- 726.

Johnson, G. H., 1969, Guidebook to the geology of the York-James Peninsula and south bank of the James River-Atlantic Coastal Plain Geologic Association, 10th annual field conference, and 1st annual Virginia geologic field conference: Williamsburg, Va., College of William and Mary, Department of Geology Guidebook 1, $33 \mathrm{p}$.

1972, Geology of the Yorktown, Poquoson West, and Poquoson East quadrangles, Virginia: Virginia Division of Mineral Resources, Report of Investigations 30,57 p.

1976, Geology of the Mulberry Island, Newport News North, and Hampton quadrangles, Virginia: Virginia Division of Mineral Resources, Report of Investigations 41, $72 \mathrm{p}$.

Jordan, R. R., 1962, Stratigraphy of the sedimentary rocks of Delaware: Delaware Geological Survey Bulletin 9, $51 \mathrm{p}$.
1974, Pleistocene deposits of Delaware, in Oaks, R. Q., Jr., and Dubar, J. R., eds., Post-Miocene stratigraphy, central and southern Atlantic Coastal Plain: Logan, Utah, Utah State University Press, p. 30-52.

Jordan, R. R., and others, 1967, Delaware-Guidebook, Atlantic Coastal Plain Geological Association, 8th annual field conference: Newark, Del., University of Delaware and Delaware Geological Survey, $[20]$ p., appendices and road log.

Kraft, J. C., 1968, Coastal sedimentary environments, LewesRehoboth Beach, Delaware-Society of Economic Paleontologists and Mineralogists Guidebook, Northeast Section, 1968 Field Trip: Newark, Del., University of Delaware, Department of Geology [13 p.].

1971, Sedimentary facies patterns and geologic history of a Holocene marine transgression: Geological Society of America Bulletin, v. 82, no. 8, p. 2131-2158.

Kraft, J. C., Allen, E. A., and Maurmeyer, E. M., 1978, The geological and paleogeomorphological evolution of a spit system and its associated coastal environments; Cape Henlopen spit, Delaware: Journal of Sedimentary Petrology, v. 48, no. 1, p. 211-226.

Kraft, J. C., and John, C. J., 1979, Lateral and vertical facies relations of transgressive barrier: American Association of Petroleum Geologists Bulletin, v. 63, no. 12, p. 2145-2163.

LeBlanc, R. J., and Hodgson, W. D., 1959, Origin and development of the Texas shoreline: Gulf Coast Association of Geological Societies Transactions, v. 9, p. 197-220.

Liddicoat, J. C., and Mixon, R. B., 1980, Paleomagnetic investigation of Pleistocene sediments in the Delmarva Peninsula, central Atlantic Coastal Plain [abs.]: Geological Society of America Abstracts with Programs, v. 12, no. 2, p. 70.

Maher, J. C. 1971, Geologic framework and petroleum potential of the Atlantic Coastal Plain and Continental Shelf: U.S. Geological Survey Professional Paper 659, 98 p.

Mansfield, W. C., 1928, Notes on the Pleistocene faunas from Maryland and Virginia and Pliocene and Pleistocene faunas from North Carolina: U.S. Geological Survey Professional Paper 150, p. $129-140$.

1943, Stratigraphy of the Miocene of Virginia and the Miocene and Pliocene of North Carolina, in Gardner, Julia, Mollusca from the Miocene and lower Pliocene of Virginia and North Carolina: Pt. 1, Pelecypoda: U.S. Geological Survey Professional Paper 199-A, p. 1-19.

Meisburger, E. P., 1972, Geomorphology and sediments of the Chesapeake Bay entrance: U.S. Army Corps of Engineers, Coastal Engineering Research Center, Washington, D. C., Technical Memorandum 38,61 p.

Middleton, G. V., 1973, Johannes Walther's law of the correlation of facies: Geological Society of America Bulletin, v. 84, no. 3, p. 979-988.

Mixon, R. B., Hazel, J. E., Rubin, Meyer, Sirkin, L. A., and Szabo, B. J., 1974, Geologic framework of the southernmost Delmarva Peninsula, Accomack and Northampton Counties, Virginia [abs.]: Geological Society of America Abstracts with Programs, v. 6, no. 1, p. 56-57.

Mixon, R. B., and Newell, W. L., 1977, Stafford fault system: Structures documenting Cretaceous and Tertiary deformation along the Fall Line in northeastern Virginia: Geology, v. 5, no. 7, p. 437-440.

Mixon, R. B., and Pilkey, O. H., 1976, Reconnaissance geology of the submerged and emerged Coastal Plain province, Cape Lookout area, North Carolina: U.S. Geological Survey Professional Paper 859,45 p. 
Mixon, R. B., Szabo, B. J., and Owens, J. P., 1982, Uranium-series dating of mollusks and corals, and age of Pleistocene deposits, Chesapeake Bay area, Virginia and Maryland: U.S. Geological Survey Professional Paper 1067-E, 18 p.

Newman, W. S., and Munsart, C. A., 1968, Holocene geology of the Wachapreague lagoon, Eastern Shore Peninsula, Virginia: Marine Geology, v. 6, no. 2, p. 81-105.

Newman, W. S., and Rusnak, G. A., 1965, Holocene submergence of the Eastern Shore of Virginia: Science, v. 148, no. 3678, p. 1464-1466.

Oaks, R. Q., Jr., and Coch, N. K., 1973, Post-Miocene stratigraphy and morphology, southeastern Virginia: Virginia Division of Mineral Resources Bulletin 82, $135 \mathrm{p}$.

Owens, J. P., and Denny, C. S., 1978, Geologic map of Worcester County: Baltimore, Maryland Geological Survey, scale 1:62,500. 1979a, Geologic map of Wicomico County: Baltimore, Maryland Geological Survey, scale 1:62,500.

1979b, Upper Cenozoic deposits of the central Delmarva Peninsula, Maryland and Delaware: U.S. Geological Survey Professional Paper 1067-A, $28 \mathrm{p}$.

Owens, J. P., and Minard, J. P., 1979, Upper Cenozoic sediments of the lower Delaware Valley and the northern Delmarva Peninsula, New Jersey, Pennsylvania, Delaware, and Maryland: U.S. Geological Survey Professional Paper 1067-D, 47 p.

Rasmussen, W. C., and Slaughter, T. H., 1955, The ground-water resources, in The water resources of Somerset, Wicomico, and Worcester Counties: Maryland Department of Geology, Mines and Water Resources Bulletin 16, p. 1-170.

Robbins, E. I., Perry, W. J., Jr., and Doyle, J. A., 1975, Palynological and stratigraphic investigations of four deep wells in the
Salisbury Embayment of the Atlantic Coastal Plain: U.S. Geological Survey Open-File Report 75-307, 120 p.

Sinnott, Allen, and Tibbitts, G. C., Jr., 1968, Ground-water resources of Accomack and Northampton Counties, Virginia: Virginia Division of Mineral Resources, Mineral Resources Report 9, $113 \mathrm{p}$.

Thom, B. G., 1967, Coastal and fluvial landforms-Horry and Marion Counties, South Carolina-U.S. Office of Naval Research, Geography Branch, Project Nonr 1575 (03), Technical Report: Louisiana State University Coastal Studies Institute Technical Report 44, 75 p.

1970, Carolina bays in Horry and Marion Counties, South Carolina: Geological Society of America Bulletin, v. 81, no. 3, p. 783-813.

Thompson, W. O., 1937, Original structures of beaches, bars, and dunes: Geological Society of America Bulletin, v. 48, no. 6, p. 723-752.

Valentine, P. C., 1971, Climatic implications of a late Pleistocene ostracode assemblage from southeastern Virginia: U.S. Geological Survey Professional Paper 683-D, 28 p.

Ward, L. W., and Blackwelder, B.W., 1980, Stratigraphic revision of upper Miocene and lower Pliocene beds of the Chesapeake Group, Middle Atlantic Coastal Plain: U.S. Geological Survey Bulletin $1482-\mathrm{D}, 61 \mathrm{p}$.

Weigle, J. M., 1972, Exploration and mapping of Salisbury paleochannel, Wicomico County, Maryland: Maryland Geological Survey Bulletin 31, pt. 2, p. 61-123.

1974. Availability of fresh ground water in northeastern Worcester County, Maryland; with special emphasis on the Ocean City area: Maryland Geological Survey Report of Investigations $24,63 \mathrm{p}$. 